Portland State University

PDXScholar

Summer 8-29-2013

\title{
The Consolidation of the Consociational Democracy in Lebanon: The Challenges to Democracy in Lebanon
}

Micheline Germanos Ghattas

Portland State University

Follow this and additional works at: https://pdxscholar.library.pdx.edu/open_access_etds

Part of the Islamic World and Near East History Commons, Politics and Social Change Commons, and the Public Affairs, Public Policy and Public Administration Commons

Let us know how access to this document benefits you.

\section{Recommended Citation}

Ghattas, Micheline Germanos, "The Consolidation of the Consociational Democracy in Lebanon: The Challenges to Democracy in Lebanon" (2013). Dissertations and Theses. Paper 1415.

https://doi.org/10.15760/etd.1414

This Dissertation is brought to you for free and open access. It has been accepted for inclusion in Dissertations and Theses by an authorized administrator of PDXScholar. Please contact us if we can make this document more accessible: pdxscholar@pdx.edu. 
The Consolidation of the Consociational Democracy in Lebanon:

The Challenges to Democracy in Lebanon

by

Micheline Germanos Ghattas

A dissertation submitted in partial fulfillment of the requirements for the degree of

\author{
Doctor of Philosophy \\ in \\ Public Affairs and Policy
}
Disseratation Committee:
Birol Yesilada, Chair
Phillip Cooper
Jack Corbett
Masami Nishishiba
Grant Farr

Portland State University

2013 
(C) 2013 Micheline Germanos Ghattas 


\begin{abstract}
This dissertation looks at democracy in Lebanon, a country that has a pluralistic society with many societal cleavages. The subject of this study is the consolidation of democracy in Lebanon, described by Arend Lijphart as a "consociational democracy". The research question and sub-question posed are:
\end{abstract}

1- How consolidated is democracy in Lebanon?

2- What are the challenges facing the consolidation of democracy in Lebanon?

The preamble of the 1926 Lebanese Constitution declares the country to be a parliamentary democratic republic. The political regime is a democracy, but one that is not built on the rule of the majority in numbers, since the numbers do not reflect the history of the country and its distinguishing characteristics. The division of power is built on religion, which defies the concept prevailing in western democracies of the separation between church and state. As the internal and the external conditions change, sometimes in a violent manner, the democracy in the country still survives. Today, after the war that ravaged Lebanon from 1975 to 1990, the Syrian occupation that lasted until 2005, the Israeli war in the summer of 2006, and the roadblocks in the face of the overdue presidential election in 2008, democracy is still struggling to stay alive in the country. There is no denying or ignoring the challenges and the attempts against democracy in Lebanon from 1975 to the present. Even with these challenges, there are some strong 
elements that let democracy survive all these predicaments. The reasons and events of the 1975-1995 war are still being sorted out and only history will clear that up. Can we say today that the Consociational democracy in Lebanon is consolidated? To answer this question Linz \& Stepan's three elements of a consolidated democracy are used as the criteria: the constitution of the land, people's attitude towards democracy and their behavior. The analysis examines the Lebanese Constitution, surveys about people's attitude towards democracy, and reported events about their behavior, such as political demonstrations and political violence narrated in the media. The findings of this study show that although the Lebanese find democracy as being the only game in town, the consolidation of democracy in the country still faces some challenges, both internal and external. The study also shows that the criteria used for western democracies need to be adjusted to apply to a society such as the one in Lebanon: plural, religious and traditional. 


\section{Dedication}

To my family: my husband Raymond, daughters Maya and Chloé, and son Patrick. Without their support I would have not been able to finish this work. To my Mom. 


\section{Table of Contents}

Abstract $\quad$ i

Dedication

List of Tables $\quad$ V

List of Figures vii

Introduction 1

Historical and cultural background of Lebanon $\quad 4$

$\begin{array}{ll}\text { Literature review and theoretical framework } & 17\end{array}$

Analytic framework and methodology 31

Analysis of democratic consolidation in Lebanon: 39

$\begin{array}{ll}\text { The behavioral variable } & 39\end{array}$

The attitudinal variable $\quad 45$

$\begin{array}{ll}\text { The constitutional variable } & 118\end{array}$

Challenges to the consolidation of democracy in Lebanon: 147

$\begin{array}{ll}\text { The external challenges } & 147\end{array}$

$\begin{array}{ll}\text { The internal challenges } & 149\end{array}$

$\begin{array}{ll}\text { Conclusion and prospects } & 174\end{array}$

$\begin{array}{ll}\text { References } & 185\end{array}$

$\begin{array}{ll}\text { References for the surveys } & 201\end{array}$

Appendix A: Lists of Political Demonstrations in Lebanon 207

$\begin{array}{ll}\text { Appendix B: The Surveys } & 208\end{array}$

The attitudinal factor in determining the consolidation of democracy 208

$\begin{array}{ll}\text { Chronological list of the surveys } & 209\end{array}$ 


\section{List of Tables}

Table 1. Lebanese attitudes towards national identity, voting and democratic institutions.

Table 2. Lebanese perceptions of politics, leadership, and current events in the country.

Table 3. Do the Lebanese practice democracy?

Table 4. Commitment of Lebanese to political parties.

Table 5. How real administrative reform would be realized.

Table 8: \% of Lebanese seeing Hezbollah's arms as necessary to face Israel, along religious rites.

Table 9: Do Hezbollah's arms play into the Syrian-Iranian Agenda? ----- 110

Table 10: Should Hezbollah merge with the army? 
Table11: Should Hezbollah be disarmed?-------------------------------------- 111 


\section{List of Figures}

Figure 1: The importance in Lebanon of freedoms associated with democracy. ---- 49

Figure 2: The importance in Lebanon of freedoms associated with democracy. --- 49

Figure 3. Is there freedom of expression in Lebanon? ------------------------------ 51

Figure 4. Is there democracy in Lebanon? Is there a true opposition? ------------ 55

Figure 5: How different religious rites look at opposition and at democracy in the

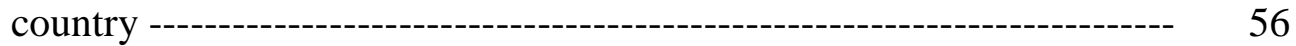

Figure 6: Is political life democratic? Respondents grouped by education level ---- 57

Figure 7. To whom should the government answer? 200 days into the term

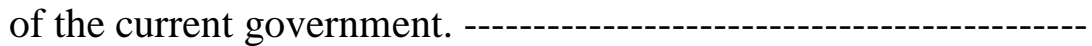

Figure 8: To whom should the government answer? 300 days into the term ----- $\quad 60$

Figure 9: A military government is not acceptable, by religious rites.

Figure 10: Did the 1975-1990 war accomplish its goal?

Figure 11: Would follow voting instructions from religious leaders, along religious rites.

Figure 12: Preference for a political party and for a peaceful political transition -- 79

Figure 13: 2000 parliamentary elections 
Figure 14: Preferred Occupation for Political Candidates.

Figure 15: Can A Political Opinion Be Imposed By Force?----------------------

Figure 16: Opposition to the 2004 President's Mandate Extension.--------------

Figure 17: Opposition to the 2004 president's mandate extension, by religious rites ----------------------------------------------------------------------------

Figure 18: Opposition to the President's Mandate Extension by Religion ------ 


\section{Introduction}

In 1974, Lebanon was governed under a democratic regime, and was given a Freedom House rating of Free and a Polity IV rating of 5 out of 10 for democracy. As a result of fifteen years of war starting in 1975, an occupation by an authoritarian regime for another fifteen years and an invasion by another neighboring country, Lebanon lost significant ground in its democracy and freedom ranking. The country is now gradually obtaining better scores on the Freedom House ratings and the Polity IV scale. Presidential elections took place in 2008, and parliamentary elections in June of 2009. After years of being rated Not Free by Freedom House (starting in 1975) and an interruption of rating by Polity IV, it is currently rated as Partly Free and has a score of 8 for democracy by Polity IV. Add to that the fact that the country has a plural society made up of eighteen different religious sects and seventy-eight political parties at last count, all of whom share in the governing process. There are also thousands of active non-governmental agencies and associations. The country has a multitude of newspapers and commercial television and radio stations that are independent from the government. With such a background, and having gone through major conflicts and violence for the last three decades, how can the regime in Lebanon be described today, and to what degree is the democracy in the country stable or consolidated? Located at the heart of the Middle East, it is definitely affected by the tension in the area, but at the same time its regime could offer a template to be used in the neighboring Arab countries. 
The works that examine democracy range from the conditions of democracy (Dahl, 1988) to those concerned with the role of the elites and political parties (Eldersveld, 1989, 2000; Huntington, 1968, 1991; Lijphart, 1977; Putnam, 1976, 1993, 1995; Yesilada, 1999, 2002;), to those distinguishing between the different levels of democracy and the role of education and economic development in the promotion of democracy (Inglehart 1997, 2005), and those exploring how to measure the consolidation of democracy (Linz \& Stepan, 1996). In western democratic theory, democracy thrives on conflict, and on mass participation channeled through political parties and/or local associations or non-governmental organizations. Quite a few authors have looked at social and moral capital, the role of institutions, the importance of non-profits and volunteer associations in instilling trust and in creating strong community ties (Almond \& Verba, 1989; O’Connell, 1999; Putnam, 2000; Reid, 1999; Salomon, 1999; Selznick, 1992). How do these factors play out in the democracy in Lebanon?

Before examining the regime in Lebanon, a cultural and historical overview of the country is necessary to shed light on the particularities of its political system. In studying the democracy in Lebanon, we should keep in mind that any political system is a product of the society it is regulating, and is influenced by the local values, traditions, history, economy and many other local factors. The political system cannot be imported as one imports a washing machine or a refrigerator; it should come from within (Sayah, 2001). At the same time, and to a certain degree, the political system also influences the society of which it is a part (Almond \& Verba, 1989). Consequently, and before we study the 
unique system in place in Lebanon, it is necessary to have the relevant historical and cultural contexts. 


\section{Historical and Cultural Background of Lebanon}

The Lebanese society is a plural society made up of eighteen different religious sects with different ideological, ethnic, and cultural lines. It is made up of segments divided along what Harry Eckstein (in Lijphart, 1977) “calls 'segmental cleavages'. Segmental cleavages may be of a religious, ideological, linguistic, regional, cultural, racial or ethnic nature. A further characteristic of a plural society is that political parties, interest groups, media of communication, schools, and voluntary associations tend to be organized along the lines of segmental cleavages" (Lijphart, 1977: 3, 4). His words very closely describe the Lebanese social and political scenes. This make-up of the society necessitates a special type of democracy that respects the demands of all factions and avoids the tyranny of the majority, as well as that of the minority. In a society as plural as that of Lebanon, it is not enough to simply live together or side-by-side. As Kareem Pakradoni declares in a popular talk show on the LBC television station "that is easy to do and is done in many countries around the world. The key and what should be accomplished is to govern together, to share the power. Democracy allows for that, and where democracy has entered it does not leave!"(2007).

The preamble of the 1926 Lebanese Constitution declares the country as a parliamentary democratic republic. The independence from the French Mandate was gained in 1943 under the same constitution and a "National Pact" that lasted until 1975. In 1975 the Middle East conflict exploded on the Lebanese soil, or, to use the words of 
Ghassan Tueni, a prominent statesman and journalist, when "the war of others exploded on the Lebanese territory."

The war started in April of 1975, sparked by an incident between Palestinian refugees and the Kataeb political party. Two statements issued in July of 1975, one by the council of the Maronite Bishops and another by the Standing Committee of National Dialogue, addressed the causes that led to the explosion of the war in April. The Committee was made up of personalities from different religious, professional and political backgrounds, including professors, religious men, politicians and parliament members. The following is a direct translation and quote of the two statements published in An-Nahar newspaper in its July 24,1975 edition for the Bishops' statement, and of July 25, 1975 for the Committee of National Dialogue.

The Council of Bishops published in An-Nahar newspaper on July 24, 1975, page 4 related the causes of the war to the following:

- "Decline in morality and values

- Lack of feeling of responsibility

- Rampant corruption

- Poverty and feeling of deprivation

- Social struggle between a destructive left and a petrified right 
- Absence of government, paralysis of institutions, and disabling the role of the army

- Gates to the country wide open to strangers

- Freedom turned into chaos

- Proliferation of arms

- Personal gain overcame common good."

The statement issued by the Standing Committee of National Dialogue saw the reasons for the violent explosions as follows:

\section{"Internal Causes}

- Absence of government.

- Reactive behavior of the Lebanese citizen and faulty assumptions, along with rumors that incite violent reactions among parties, families, factions and individuals.

- The distortion of freedom into chaos.

- Violent tendencies and currents replaced the interaction between liberties and cultures.

- Worsening of the social and economic discrepancies between regions and factions. 
- Worsening of the rigid and traditional tribalism as a result of the government encouragement to it and of the stocking of arms. Also as a result of the government discriminating against the opposition parties.

- Neglecting to strengthen the army and the internal security forces.

- Appearance of political movements based on the conviction that tribal, feudal, and patriarchal violence cannot be fought through democracy but only through violence.

- Deformation of the traditional political parties from means of democratic competition into militias that impose their will through violence.

- Lack of government response to the demands of social associations, syndicates, women and students unless they resorted to strikes and violence.

- Disagreement about the national identity and struggle around national destiny.

- Failing at fulfilling national duties, a failure that weakens national spirit and the feeling of trust among the citizens of the same nation. It also leads to the feeling that the vertical growth of one confession is but a threat to the existence of the others, and 
therefore necessitates a race to be armed for self-defense and to protect their acquired rights.

- Collapse of spiritual values, be it Christian or Muslim or moral values.

- Many infractions of the laws, of security and of mutually agreed upon pacts by armed Lebanese and Palestinians factions.

\section{External Causes}

- Foreign intelligence agencies using money, arms and terrorists all over the world to murder personalities and to eliminate rival political groups.

- Attempt by Israel to create an internal front to distract the Palestinians and to ruin the Lebanese model of democratic cohabitation and to stop the progress of national unity.

- In a new world order of international tendency towards violence, nuclear balance, imperialism under a new form of dividing up the

world, spending on technology and the balance of fear instead of spending on development and aid to poor countries, there is a belief in the third world, and in Lebanon, that "holy violence" is the only way to change this current state of affairs. 
- And lastly, the rise of efficiency and power of the arms' dealers, smugglers and sellers, the Lebanese ones in cooperation with the agents of the big powers."

The "National Pact" put in place the Consociational democracy, and it lasted for over thirty years. The regime in Lebanon is a mixture of traditional and democratic norms that reflect the complexity and diversity of the Lebanese society. It has elements of a traditional society built on family and blood ties, but it also depends on modern contractbased ties (Weber, 1947). The political regime in Lebanon is a democracy, but a democracy that is not built on the rule of majority in numbers. It is also a regime where the division of powers is built on religion, which defies the concept of the separation between church and state prevailing in western democracies. As the internal and the external conditions change, sometimes violently, the regime in the country remains that of a parliamentary republic. Quite a few Lebanese writers and researchers find that the active civil society, and specifically, the presence and work of the NGOs were the glue that kept the society together and saved it from disintegration and from disappearing all together (Al-Sayid,1995; Mhanna, 2001 ). That is a crucial element to consider, especially when the country is not only facing internal dangers but also considerable interference and pressure from neighboring countries, and as a result of its strategic location and the make-up of its society. 
Today, after fifteen years of war, followed by the Syrian occupation of the country until 2005 , the Israeli war in the summer of 2006, and the roadblocks in the face of the overdue presidential election in 2008, democracy, albeit with deficiencies, is still the governing regime in Lebanon. Without ignoring or denying the challenges and the attempts against democracy in Lebanon from 1975 to the present, one sees some strong elements that let a democratic regime survive after all those events. Even though the regime in Lebanon does not fit into the mold of western democracies, it is still a "Parliamentary Democratic Republic" as it is declared in the Preamble to the Constitution.

It is of interest to note that throughout the war the parliament kept trying to fulfill its obligations and to meet. However, after a while, it became impossible to do so as a result of the shelling and of the fact that the Parliament building was in one of the most dangerous areas of Beirut. The government and the President also tried to fulfill their functions as much as the circumstances allowed and to try to negotiate ceasefires. Presidential and parliamentary elections took place under fire and in safer places than in the downtown Beirut area, their official seat.

Economically the country has had and still has a unique situation compared to the other countries in the region: it does not have any natural resources on which to depend for income, no oil wells or minerals. It does, however, have a free market economy 
thriving on commerce and on services such as tourism and the financial sector. Charles Harvie and Ali Saleh write:

Beirut was the financial center for the Middle East in the 1960s and early 1970s, having the largest number of representative offices of foreign banks in the Arab world, and was the regional headquarters for many international companies. Lebanon's economic stability, characterized by low inflation, high rates of economic growth, large balance of payment surpluses, small budget deficits, a floating, stable and fully convertible domestic currency, and political stability, made it a highly attractive business center. (Saleh and Harvie, in MERIA Jan. 2005)

\section{The Distinct Nature of the Lebanese Society and the Special Make-Up of the Lebanese Republic}

The fact that Lebanon is situated in an important geographical location on the eastern end of the Mediterranean made the country vulnerable to invasions and struggles. At the same time, its being a passageway between east and west, a land where Muslim, Christian, and Jewish civilizations interact, created a diversity and a richness respected and admired by the surrounding countries. With such a diversity and freedom, the 
political system of the country may consequently be a template that could be applied in the region, or at least offer homegrown ways that could lead towards democracy.

In the words of Pope John Paul II, during his visit to the country in 1997, "Lebanon is a message" where Christians and Muslims live side by side in peace, where civilizations live together and enrich each other rather than clash against each other (an answer and an anti-dote to Huntington's clash of civilizations (Corm, 2002; Dagher, 2002). Lebanon is a state where freedom of religion, of association, of speech and of thought is a tradition. The country is a refuge for all the persecuted in the Middle East including the Maronite Catholics who found refuge and safety in the rugged hills of Mount Lebanon and whose monks have built their monasteries on the steep mountains and provided sanctuaries to the Maronites since the early seventh century (Awit, 1989). It was also a refuge for the Druze who fled from Egypt the persecution and killing by the Fatimids around 1021. Even under the rule of the Ottoman Empire, and as far back as the sixteenth century, the Mount Lebanon enjoyed a large degree of autonomy during the rule of the Ma'an Emirs and then the Shehabis in the nineteenth century (Daou, 1977). That history of freedom and the quality of a safe refuge is at the basis of what Daniel Hanna termed as the "culture of democracy" in Lebanon (Hanna, 2008).

The Christians in the Lebanese society have been subjected to many dangers and to considerable pressure to lead them to emigrate from the country. Repeated references are made in the literature and media (Sakr, 2005; Tueni, 2008) to a conspiracy concocted 
by Henry Kissinger and by Ambassador Dean Brown, the United States Special Envoy to Lebanon during the Ford administration. Offers were made to the Lebanese Christian population encouraging them to emigrate from Lebanon. That would not only put an end to the war in the country but it would also solve the Middle East conflict by replacing the Christians with the Palestinian refugees. It would also be justifying the one-religion nature of Israel (Tueni, 2008).

Sayyed Mohammed Hussein Fadlallah, a prominent Shiite figure, speaking about the 1975-1990 war in Lebanon, stated that "the war in Lebanon has never been Lebanese, but the result of international decisions that exploited the complexity of Lebanon" (as cited in Khalifé, 2005 : 7). The Maronite Patriarch at the time, Mar Nasrallah Boutros Sfeir, agreed saying that "if we base our statement on historical facts we quickly realize that the Lebanese war was never a religious war and even less a civil war, contrary to the allegations of many" (Khalifé, 2005: 7).

The historical presence of the Christians in Lebanon, and in the region, is a synthesis between East and West, Christianity and Islam, the Arab and European thoughts (specifically the French thoughts). As Fares Souhaid, a prominent political figure and member of the parliament put it, the Lebanese Christians, and in particular the Maronites, think both as Christians and as Muslims. They are the only Arabs with one foot in the Arab culture and the other in the Western culture (Souhaid, 2008). They can offer a rare look into what the two cultures and the two religions combined can offer, and 
an antidote to and a rebuke of Huntington's idea of the "clash of civilizations" (Corm, 2005; Dagher, 2002). Abdel-Hamid el-Ahdab in an article published in L'Orient-Le Jour wrote that the Lebanese Christian thinkers launched the concept of secularism and of an Arabism that is non-religious and non-clannish (el-Ahdab, 2003). In that same vein, and in the words of Habib Malik who wrote in MERIA:

The freest Christian community in the Middle East kept Lebanon open to more than Western commodities and technical know-how; it also accessed the deepest values in Western traditions. It built up the country's free institutions in the economic and political realms. It bestowed on Beirut the freest press in the Arab world, a liberal atmosphere of free inquiry in its private universities, and a political system in which the leaders actually retired. Were it not for the presence in the city, and in Lebanon as a whole, of a vibrant, creative, and relatively secure indigenous Christian community, (---) Beirut would be indistinguishable from its sullen and drab sister metropolises throughout the Arab and Islamic east. With Lebanon's Christians free, the country's pluralist character has demonstrated its ability to spawn cultural creativity of a highly varied and novel sort -- in art, poetry, literature, music, architecture, entertainment, and more. Clearly, Lebanon minus its free Christians would quickly turn into a monochromatic version of Syria. Muslims in Lebanon generally like the free and open Beirut they have come to know. On the whole, they do not wish to replace it with a 
version of Tehran or Kabul, though they often do lose sight of the fact that the city they so cherish is contingent on a continued free Christian presence. (Malik, 1998: 2)

The Lebanese Republic has no official religion, contrary to the surrounding countries in the region. Its political model, however, even though it is a democracy, is based on the equal sharing of power among different religious segments. The idea of basing power sharing on the religious affiliation is inherently contrary to the western concept of democracy and of the separation of state and religion. In Lebanon, religion is part of one's identity and cannot be ignored when looking at the system in place and trying to understand it (Laurent, 2006: 4). The presence of the many religious sects is looked at as richness, and the weave they all make as a very unique and precious living message. "Believing in God and in Lebanon" is at the basis of belonging to the Lebanese society, and the plurality and diversity of this society are precious threads in the Lebanese fabric $^{1}$. The Shiite view does not differ much from the Sunni position towards the diverse make up of the Lebanese society. The Shiites see Lebanon as their definitive homeland, and the country founded on a partnership of all its citizens who share the same destiny ${ }^{2}$. The Druzes also believe in the plurality of Lebanon, and in the necessity and the importance of the presence of the Christian citizens in Lebanon but also in the Arab

${ }^{1}$ According to M. Assamak, advisor to the Mufti of the Lebanese Republic, as cited in Laurent, 2006: 10

2 According to Dr. Almaoula, from the Shiite Superior Council, as cited in Laurent, 2006 
world (Laurent, 2006) ${ }^{3}$. All of the major religious communities see the diversity and pluralism of the Lebanese society as a source of richness rather than one of conflict.

Such a background and reality set apart the regime in Lebanon. It does not fit perfectly in the mold of the western democracies, yet it has many of the elements of a democratic regime governing in a diverse but traditional society. It is a consociational democracy that is based on the liberties associated with a western democratic regime, on the presence and actions of many political parties, on an active civil society rich with NGOs and local charitable and political associations, and on a "culture of democracy" (Hanna, 2008).

If Lebanon has all these elements of a democratic regime, and all of the freedoms and institutions associated with a democracy, why hasn't the political experiment in Lebanon brought about a stable or a consolidated democracy? In order to analyze the challenges to the democracy in Lebanon, it is essential to review the theoretical literature on this subject.

${ }^{3}$ M. al-Halaby, from the Druze community as cited in Laurent, 2006 


\section{Literature Review and Theoretical Framework}

In Western democratic theories, and using Robert Dahl's (1998) definition, a regime is qualified as democratic when the following conditions are present: the military and police are controlled by elected officials, democratic beliefs are prevalent in the political culture, and the regime is free from strong foreign control hostile to democracy. A modern market economy is another favorable condition. A western style representative liberal democracy is manifested through "four basic democratic institutions: free and fair elections, freedom of expression, alternative and independent sources of information, and associational autonomy”( Dahl, 1998: 197).

Democracy co-exists with conflict, it necessitates and even breeds conflict, but it is also built on means of conflict resolution that put a large emphasis on the process, on the participation of elites and non-elites alike in making decisions and finding compromises (Eldersveld, 1989). The role political parties play in this process is also important, as they provide an organizational base for elites to compete and to mobilize the masses. They are both "integrative and competitive" (Eldersveld \& Walton, 2000: 14). The political parties recruit leaders, formulate policy, and mobilize support (Eldersveld \& Walton, 2000). They provide a linkage between the citizens and the government. They allow for some sort of accountability towards the public, and a way to let the masses' needs be known. The local structures of parties "maintain close relations to the public, select candidates, raise money, recruit personnel, and determine issue 
positions" (Eldersveld \& Walton ,2000: 144). They also have an educational function informing citizens about the issues, the candidates and the votes. The parties allow for a "meaningful citizen participation, governmental stability, maintenance of public order, effective representation of social groups, responsiveness of the elites to mass needs and problems, and increasing acceptance of the political values of democracy" (Eldersveld \& Walton, 2000: 411). The leaders in these parties or the elites have "significant national influence" (Putnam, 1976: 46). They arrive to influential positions through permeable channels from other professions and fields such as the business field, from the institutions in place such as the parties or the military or the local universities (Putnam, 1976). In addition to the political society, civil society plays an important role in democracy. Many authors looked at civil society as providing means of democratic participation, of engaging the "disengaged" citizen and an answer to the "bowling alone" syndrome (Putnam, 2000), also as a way to participate in the life of the community (Selznick, 1992). Almond and Verba (1989) studied how the local society influences but at the same time is influenced by the local values, traditions, history, and economy. The level of education and the socio-economic status play an equally important role in the degree of democracy and the quality of a democratic regime (Inglehart \& Wenzel. 2007; Inglehart, 1997). How does all this apply to the political system in Lebanon?

The political system in Lebanon is what Arend Lijphart terms as a "consociational democracy". This form of democracy occurs where "the centrifugal tendencies inherent in a plural society are counteracted by the cooperative attitudes and behavior of the 
leaders of the different segments of the population" (Lijphart, 1977: 1). Lijphart studied the regime in plural societies in four continental European countries and three countries in the Third world. He examined Consociational democracies in Switzerland, Belgium, the Netherlands and Austria, as well as those in Lebanon, Indonesia and Cyprus. According to Lijphart (1977: 25):

"Consociational democracy can be defined in terms of four characteristics. The first and most important element is government by a grand coalition of the political leaders of all significant segments of the plural society. This can take several different forms, such as a grand coalition cabinet in a parliamentary system, a grand council or committee with important advisory functions, or a grand coalition of a president and other top office holders in a presidential system. The other three basic elements of consociational democracy are (1) the mutual veto or "concurrent majority" rule, which serves as an additional protection of vital minority interests, (2) proportionality as the principal standard of political representation, civil service appointments, and allocation of public funds, and (3) a high degree of autonomy for each segment to run its own internal affairs."

A democracy can be described as consolidated when it is seen by the citizens as the "only game in town" (Linz \& Stepan, 1996: 5). That would be seen through the attitudes and the behavior of these citizens, and through the constitution. This point will 
be elaborated in further detail below, and the tools that Linz \& Stepan established will be used to determine whether the Consociational democracy in Lebanon is consolidated.

In a Consociational democracy, a "grand coalition" is the only feasible way to include minorities in the government. To have a grand coalition "a moderate attitude and a willingness to compromise are prerequisites" (Lijphart, 1977: 31). To encourage moderation and the willingness to compromise, "the prospect of participating in the government is a powerful stimulus" (Lijphart, 1977: 31). "Another possibility is to make an arrangement in which the presidency is linked with a number of other top executive posts, such as those of the prime minister, deputy prime minister, and speaker of the assembly. Together, these can become a grand coalition, as in Lebanon" (Lijphart, 1977: 34).

In this form of democracy, minority veto is used to avoid the tyranny of the majority. It might, however, lead to the tyranny of the minority, if the minorities abuse their veto power and lead to the paralysis of the government. Lijphart finds that "each segment will recognize the danger of deadlock and immobilism that is likely to result from an unrestrained use of the veto" (Lijphart, 1977: 37); he hopes that veto power will simply remain in the background as a tool or a guarantee to provide equal power to all factions in the government.

The third component of a Consociational democracy is proportionality. It is "a method of allocating civil service appointments and scarce financial resources in the form 
of government subsidies among the different segments" (Lijphart, 1977: 38). Proportionality leads to the over-representation of a minority group in government as a way of making all groups equal (Lijphart, 1977: 41), but, at the same time, provides a sense of security to the minority factions.

The fourth part of a Consociational democracy is segmental autonomy, the "rule of the minority over itself in the area of the minority's exclusive concern. It is the logical corollary of the grand coalition principle. On all matters of common interest, decisions should be made by all of the segments together with roughly proportional degrees of influence. On all other matters, however, the decisions and their execution can be left to the separate segments “(Lijphart, 1977: 41).

On the political scene, the "grand coalition" mentioned above is essentially between the leaders, or the "elites" (Eldesveld and Walton, 2000), or the "influentials" and the "decision makers" (Putnam, 1976) of each segment. In Consociational democracies, as in other democracies, the elites represent and lead their parties through the political process and elections. They are also the basis of the "grand coalition": they are the ones who lead their supporters into grand coalitions with the other segments of the plural society. Without them the system grinds to a halt or leads to the tyranny of one group over the others (Lijphart, 1977). These elites also "feel at least some commitment to the maintenance of the unity of the country as well as a commitment to democratic practices" (Lijphart, $1977: 53)$. 
Democracy is consolidated when it seems to be "the only game in town" (Linz \& Stepan, 1996: 5), as manifested through the behavior and the attitude of the citizens, and through the application of the constitution. Behaviorally the democratic regime is consolidated when no significant national, social, political, economic or institutional actor tries to achieve his or her objective through non-democratic or violent means. Behaviorally, democracy is the only game in town "when no significant political group seriously attempt to overthrow the democratic regime or secede from the state" (Linz \& Stepan 1996: 5). Attitudinally, democracy is consolidated when the majority holds the belief that no alternative to democracy is acceptable as a way of governing, "when, even in the face of severe political and economic crises, the overwhelming majority of the people believe that any further political change must emerge from within the parameter of democratic formulas" (Linz \& Stepan 1996: 5). Constitutionally democracy is consolidated when conflicts are habitually resolved within the dictates of laws, procedures and institutions established in a mutually agreed upon process (Linz \& Stepan, 1996: 6).

Linz \& Stepan looked at problems of democratic transition and consolidation in southern Europe, South America, and post-communist Europe. The idea of allowing all existing political forces to participate in the political process, including those that are against democracy, creates an inclusive society. It also avoids the resentment and the persecution and jailing that result from banning and disallowing certain factions (Linz \& Stepan, 1996: 97). That all-inclusive government echoes the "grand coalition" in 
Lijphart's Consociational democracy, where all segments are participating, in one way or another, in the country's administration.

Democracy is not limited to the political or civil arenas, and it is "much more than elections and markets" (Linz \& Stepan, 1996 : 7). It is in five different arenas that are complementary, interdependent and inseparable. Civil society is a stepping stone and a training ground for the second arena, the political society. The political society is manifested in the political parties, the elections and elected governmental bodies. "A robust civil society, with the capacity to generate political alternatives and to monitor government and state can help (...) consolidate, and help deepen democracy" (Linz \& Stepan, 1996: 9). The rule of law, a usable state and an economic society are the other three arenas of a consolidated democracy. They echo or parallel the manifestations of what Lijphart called a stable democracy. These arenas also parallel the conditions for democracy and the institutions present in a democracy as seen by Robert Dahl (1998). For all these authors, these arenas remain interdependent, complementary and inseparable.

\section{The Civil Society}

Are the citizens engaged? Are they active in the local associations, syndicates, or charitable organizations? (These non-governmental associations will be grouped under the term of NGOs.) Do they believe in democracy and the liberties on which a democratic regime is based? Are they well versed in their rights, but also their duties as citizens? In a 
civil society, participating could be in the form of any nongovernmental organization that provides a service or satisfies a need in society. Mass participation could be done through social channels. Civic groups, labor unions, business associations and the church could function as a way for the masses to participate. S. Rokkan (in LaPalombara ed. 1966) saw the importance of voluntary associations, but also of international organizations in the promotion of democracy and in providing channels of participation for the masses. It is a giant leap toward a consolidated democracy if the civil society is active and protected from persecution. Tolerance of opposition and of associations other than that of the government is not typically a trait of authoritarian regimes. The presence therefore of NGOs, or of any other manifestation of civic engagement, is an important element in establishing and consolidating democracy.

In western societies the latest literature focused on engaging the socially disengaged individual, a manifestation of a weakening social capital, of a "bowling alone" (Putnam, 2000) syndrome. In developing societies, the intermediary associations play a larger role in channeling mass participation in both social and political activities, in advocacy, and in complementing the government's role. They are an intermediary between the individual and the government, and could also be considered as a channel for the citizen to play a role in the public arena and in the political arena. In addition to these functions, they too, like political parties, play the important role of educating the individuals in their role as citizens (Khalaf, 2008). 
Volunteering in a charitable association means having the freedom to do what one wishes with his or her time, and for whichever cause the individual deems appealing. Volunteering does not exist on a large scale in authoritarian or military systems. Freedom of association is not a regime value, and groups of any kind are a threat to those who monopolize the power. The "discourse of liberty centers on the capacity for voluntarism. Action is voluntary if it is intended by rational actors who are in full control of body and mind" (Alexander,1992: 295). Therefore the presence of volunteering on a large and public scale and of volunteer associations is a sign of a healthy civil society and could be a sign of a democratic regime.

Putnam used social capital and social involvement to measure the political participation: a rich social capital leads to a vigorous democracy. Neighbors involved in their community are easily transformed into citizens involved in their government. Civic organizations, such as the professional associations and the political parties, provide a forum for discussions and consequently offer an opportunity for the average citizen to influence public policy. Participation in communities, as mentioned earlier, is "mediated by participation in families, localities, personal networks, and institutions" (Selznick, 1992: 367).

\section{The Political Society}

The civil society is a training ground and a stepping stone to the political society. "Normatively, civil society implies values and behavioral codes of tolerating, if not 
accepting, the different "others" and a tacit or explicit commitment to the peaceful management of differences among individuals and collectivities sharing the same public space - i.e. the polity." (Saad Edin Ibrahim, in Norton ed. 1995: 28).

Democracy postulates political liberty, liberty to dissent, and tolerance of conflict, of contestation and of pluralism. This is where, in addition to the presence of a healthy and active civil society, the political parties take the citizens " participation into the political realm. In the western literature, the parties play an important role by providing an organizational base for the elites to compete and to mobilize the masses, to formulate policy, to provide a linkage between the citizens and the government, and to allow for some sort of accountability towards the public (Eldersveld \& Walton, 2000). Parties also have an important educational function informing citizens about the issues, the candidates and the votes. The local structures of parties "maintain close relations to the public, select candidates, raise money, recruit personnel, (and) determine issue position." (Eldersveld \& Walton, 2000, p.144). The parties allow for a "meaningful citizen participation, governmental stability, maintenance of public order, effective representation of social groups, responsiveness of elites to mass needs and problems, and increasing acceptance of the political values of democracy" (Eldersveld \& Walton, 2000, p.411). Parties alleviate the pressure coming from "mass participation" (Huntington, 1968); they act as "transmission belts for pressure from lower down"( Daalder, in LaPalombara. ed., 1966: 71). 


\section{The Economic Society}

Using the term "economic society" is meant to say that a free market cannot be purely free. It cannot be totally outside the control of all laws and regulations that protect the individual's property rights. At the same time "there has never been and there cannot be a non-wartime consolidated democracy in a command economy" (Linz \& Stepan, 1996: 11).

Education, equity in income distribution, and the availability of the basic necessities of life are important factors and conditions for an active civil society and democracy, in addition to a healthy economy. As Abootalebi explained "the rise of civil society and democracy is impossible where people must constantly worry about the basic necessities of life" (1998). It is relevant when we study the democracy in Lebanon to look at the surrounding region, and namely at the state of affairs of the neighboring Arab countries. When the state is partnering up with the military and/or the upper socioeconomic class to control the power, there is very little the poor and uneducated masses can do to bring down the authoritarian regime. The presence of intermediary and effective associations is the only way to limit the state's power and to help bring about change through collective bargaining and advocacy. When the masses lack this tool, the power will remain monopolized by the few at the top (Abootalebi, 1998). The grip of the existing regime on power is also reinforced by what Yom (2005) terms as "a controlled liberalization." The "controlled liberalization" is a result of the flexibility of the 
authoritarian regimes in the Arab world and their ability to bend and to accommodate the demands of the advocacy groups just enough to silence the protests yet keep their hold on power (Yom, 2005). In an authoritarian regime, the state, in the person of its leader, has the sole control of income. The "rentier" states, as Rivlin calls them, with income coming either from natural resources such as oil, or from foreign aid, control the income and leave little bargaining chips in the hands of the poor and unorganized masses (1997). They "exhibit extreme fiscal immaturity and few participatory institutions, reducing the number of "pressure points" by which Civil Society Organizations can press the regime for openness" (Yom, 2005: 5). The post-modern values seen in post-industrialized nations are far removed from the day-to-day needs of a struggling third world nation, or a nation at war (Inglehart \& Wenzel, 2007). " Economic growth, rising levels of education and information, and diversifying human interactions increase people's material, cognitive, and social resources, making them materially, intellectually, and socially more independent. Rising levels of existential security and autonomy change people's firsthand life experiences fundamentally, leading them to emphasize goals that were previously given lower priority, including the pursuit of freedom” (Inglehart \& Wenzel, 2007: 1).

\section{The Usable State and The Rule of Law}

The usable state is necessary to guarantee and protect the rights of its citizens, and to deliver the basic services that the citizens need. To do that a "democratic government needs to be able to exercise effectively its claim to the monopoly of the legitimate use of 
force in the territory," to be able to "tax compulsorily in order to pay for police, judges, and basic services," and to have in place a bureaucracy that expedites its citizens' needs (Linz \& Stepan, 1996). It must do so in a transparent and lawful manner.

The "rule of law" means that "all significant actors - especially the democratic government and the state - must respect and uphold the rule of law" (Linz \& Stepan, 1996: 10). The laws are upheld through a fair and independent judicial system and "supported by a strong legal culture in civil society". In this arena, the constitutional indicator for a consolidated democracy would be how habitual is the application and the respect of the law of the land, starting from the Constitution itself and how it is applied by the legislators, and to the way the judicial system is operating. The attitudinal indicator would be in the rampant belief of the citizens that the only way to resolve conflict, be it political or otherwise, must be within the parameters set by the democratically established laws and procedures. As for the behavioral indicator, no significant actor tries to resolve conflicts in violent means or any other means not authorized by law.

Dahl's definition of democracy can be applied to describe the regime in Lebanon: the police and military are controlled by elected officials, and there is a prevalent culture of democracy in the country and a modern market economy. The influence of neighboring countries inside Lebanon is still a cause of instability and will be discussed later, and so is the presence of an armed militia that operates side by side with the army 
yet is a separate entity. The liberal democracy is manifested through the freedom of expression, alternative and independent sources of information, and associational autonomy. As for the free and fair elections, these will be examined more closely as part of the analytic model. The regime in Lebanon is a democracy, albeit a special kind of democracy, a consociational democracy as labeled by Lijphart, yet how consolidated is this democracy? 


\section{Analytic Framework and Methodology}

In light of the theoretical discussion above, the main questions examined in this study are:

1- How consolidated is democracy in Lebanon?

2- What are the challenges facing consolidation of democracy in Lebanon?

To answer the two questions, this study will use the analytic framework provided by Linz \& Stepan (1996) which stipulates that:

Consolidation of democracy is a function of three factors which are constitutional, behavioral and attitudinal. Operationalization of this relationship requires identifying appropriate indicators for each variable. The dependent variable is democratic consolidation. This is measured by POLITY IV indicator of democratization. Polity IV rating is chosen because it has a more extensive set of data factored into their ratings. It also takes into consideration and calculates into the data sets the years of war in Lebanon, from 1975 through 1989, and the years of the Syrian occupation from 1989 through March of 2005. It applies a "fix" to the data accounting for the anarchy or the "interregnum" of the war years, and for the "interruption" of the Lebanese rule during the Syrian occupation.

The Independent variables are behavioral, attitudinal, and constitutional factors defined as follows: 
- Behaviorally the democratic regime is consolidated when no significant national, social, political or economic or institutional actor tries to achieve their objective through non-democratic or violent means. Behaviorally, democracy is the only game in town "when no significant political group seriously attempt to overthrow the democratic regime or secede from the state" (Linz \& Stepan, 1996: 5).

- Attitudinally, democracy is consolidated when the majority holds the belief that no alternative to democracy is acceptable as a way of governing, "when, even in the face of severe political and economic crises, the overwhelming majority of the people believe that any further political change must emerge from within the parameter of democratic formulas" (Linz \& Stepan, 1996: 5).

- Constitutionally democracy is consolidated when conflicts are habitually resolved within the dictates of laws, procedures and institutions established in a mutually agreed upon process (Linz \& Stepan, 1996: 6).

\section{Behavioral Variable}

Guided by Linz \& Stepan's definition of this variable, this study will examine how the significant political, social and economical actors in the country protected their interests. Did any of these significant actors or political groups "seriously attempt to 
overthrow the democratic regime or secede from the State" (Linz \& Stepan, 1996: 5)?

Did they follow violent means or did they use the means provided by the laws of the land? Are all "actors in the polity habituated to the fact that political conflict will be resolved according to the established norms" (Linz \& Stepan. 1996: 5)? Were the actions of the stakeholders, when protecting their interests, violent or did they fall under the rule of the law? An annual measure of political violence is a good indicator of this variable. Data about political violence were collected from reports in the An-Nahar ${ }^{4}$ newspaper. The articles published in An-Nahar were scanned for: 1- the number of violent demonstrations per month and per year 2- the number of injuries (fatal and nonfatal) resulting from political violence per month and per year.

\footnotetext{
${ }^{4}$ An-Nahar was chosen for the following reasons: Print media allows a more in-depth study of the reported news. It eliminates the aural and visual distractions. As for the choice of this particular paper, it was based on the fact that it is an independent publication not financed by a particular political party, and because of its frank approach to reporting events. In Lebanon there is an abundance of newspapers and other media outlets, printed or otherwise, that are merely mouthpieces for the different political parties. Their news reporting is done with a particular slant and according to a particular agenda. Unlike in the surrounding authoritarian regimes in the region, there is no one official and censored version of the news. There are many versions depending on the political affiliation. That is why choosing a neutral and a reputable independent newspaper to get an objective description of events, is essential. In addition to that, and during the years of the Syrian occupation of Lebanon, from 1990 to 2005, the frankness of the reports published in An-Nahar frequently led to the prosecution and persecution of its editors and reporters. Also, the An-Nahar paper has the clout, the means and the respect of the locals for it to be considered a valuable and dependable source of information.
} 
3- the number of arrests resulting from the political demonstrations per month and per year.

In order to do that, the An-Nahar articles were searched for reports on political demonstrations and politically motivated violence and compared the frequency of these events among the following periods:

-from 1970 - 1975, a period where Lebanon enjoyed calm, prosperity and stability, was rated Free by Freedom House, and had a score of 5 out of 10 in the Polity reports. This way we will be able to compare the data from the years when Lebanon was considered a free and democratic country to the data in subsequent years, during and after the Syrian occupation.

- from 1990 to February of 2005 during the occupation of Lebanon by the authoritarian Syrian regime,

- and finally from February 2005 to June of 2009, a period when Lebanon started to bounce back from the war and from the Syrian domination, into a freer political system. Stopping at 2009 will allow for a long enough time series and for the use of the most recent studies to be published. It also factors in the latest parliamentary elections in June of 2009, which took place in a country freed from the shadow of the Syrian occupation and its meddling in the internal affairs of Lebanon. 
When counting the "violent political demonstrations", the war years were not included in the calculations. The war years started on April 15, 1975 and ended in 1989, the year when the Taef agreement put an end to the fighting and brought in the Syrian forces. The full-blown war resulted in hundreds of thousands of victims.

\section{Attitudinal Variable}

Democracy is the "only game in town when, even in the face of severe political and economic crises, the overwhelming majority of the people believe that any further political change must emerge from within the parameters of democratic formulas" (Linz \& Stepan, 1996: 5).

For the attitudinal variable, the indicators include many different and equally telling and important questions. It is important to note that a direct question such as "do you believe in democracy?" is very wide-ranging and does not lead to a detailed and clear analysis of the attitudinal variable in Lebanon. That is not only because of the broad definition of democracy itself, but also and especially because of the complicated and unique situation in Lebanon. In addition to the Consociational democracy in the country, due to its segmented society, it is also affected greatly by external factors as a result to its location.

The answer then to the very general question of "do you believe that democracy is the only acceptable regime in Lebanon?" could be gleaned from the compilation of 
answers to many other sub-questions that address each one of the many "parameters of democratic formulas" (Linz \& Stepan, 1996: 5). Sub-questions such as:

- do you conceive of another regime in Lebanon?

- Do you think the current system treats everyone equally?

- Do you think confessionalism ${ }^{5}$ gets in the way of allegiance to the country?

- Do you think getting rid of confessionalism will do away with the consociational democracy?

- Do you believe in Lebanon as a sovereign independent country and a definitive homeland for its people?

- Do you trust an elected Islamic government to follow the rules of democracy?

- Do you identify with the Lebanese identity first or with the religious identity first?

The questions mentioned above were only a sample of questions asked in surveys conducted by Information International, by Statistics Lebanon, by Zoghby International, or by the Beirut Center for Research and Information. Information International is an independent regional research \& consultancy firm based in Beirut. Statistics Lebanon is a firm specializing in polling and marketing also based in Beirut. The Beirut Center for Research and Information is an independent scientific institution and a publishing

\footnotetext{
${ }^{5}$ Confessionnalism is a way, particular to Lebanon, of distributing government positions according to people's religious rites or confessions. It is meant to ensure the participation of all eighteen religious confessions in the government.
} 
company formed by researchers and university professors with a concern towards the public good, society, and democracy. They conduct research, surveys, workshops and studies, which are subsequently published by the Center. The World Values Survey would have been a rich source of data, but Lebanon is not one of the cases studied by the World Values Survey. Another important matter to consider is the fact that there were no surveys found for the time period dating back to 1970 , and needless to say, no surveys were taking place during the war years from 1975 through 1989. The oldest surveys or studies that are available date back to 1995 . Thus, the measure of the attitudinal variable relies heavily on the availability of survey data from Lebanon.

\section{Constitutional Variable}

How does the Lebanese constitution provide for the individual, civil and political liberties? And is the rule of law based on liberal democratic principles? In studying the constitutional variable we are guided by the definition Linz \& Stepan offered for this variable: the democracy is consolidated constitutionally when conflicts are "habitually resolved within the dictates of laws, procedures and institutions established in a mutually agreed upon process “(Linz \& Stepan, 1996: 6). Does the Lebanese Constitution provide for the liberties associated with a democratic regime? Does it protect the citizens' liberties and rights through a mutually agreed upon process?

In order to determine these characteristics, this study will examine the present constitution of Lebanon after the amendments made to it as a result of the Taef 
agreement. The Taef agreement put an end to the fifteen-year war in the country and was put into effect in 1990. This study uses S.E. Finer's Comparing Constitutions (1995, reprinted 2006) and follows the criteria Finer uses to compare five different constitutions from countries considered to be democratic. The study will also look at the Constitution in practice and how it was applied in resolving conflicts in the country. 


\section{Analysis of Democratic Consolidation in Lebanon}

\section{The Behavioral Variable}

While studying the behavioral component of consolidation of democracy in Lebanon, it is of value to keep in mind that the behavior does not happen in a vacuum. The historical and cultural background and circumstances mentioned earlier in the History section should be kept into focus.

As explained previously, democracy in a given country is considered to be consolidated in behavioral terms when "no significant political group seriously attempts to overthrow the democratic regime or secede from the state" (Linz \& Stepan, 1996: 5). Democracy is consolidated when no significant national, social, political, economic or institutional actor tries to achieve their objective through non-democratic or violent means. For the purpose of this study the non-democratic means are represented by the number of violent political demonstrations or events and the number of victims resulting from these events.

\section{The Data.}

Appendix A provides the spreadsheets that show the number of occurrences of political demonstrations monthly along with the number of victims and the number of arrests. The information is taken from the reports in the daily independent newspaper An-Nahar. 
In the spreadsheets the events are recorded in three groupings:

1- from January 1970 through April of 1975 when the war started

2- from 1990 until February of 2005, the years of the Syrian occupation of the country which ended with the assassination of Prime Minister Rafik Hariri and the resulting Cedar Revolution that pushed the Syrian forces out of Lebanon.

3- a final grouping that starts in March 2005 and ends in June 2009 with the parliamentary elections.

The number of demonstrations was the lowest during the Syrian occupation at 161 demonstrations in fifteen years. There were 254 demonstrations in the period of four and a half years from 2005 to 2009 , and 381 demonstrations in the five-year period between 1970 and 1975. The violent events, other than demonstrations, which claimed the most victims at one time, were the clashes with the Israelis, or between the Palestinians and the Lebanese army, or between the Palestinians and the Kata'eb political party. In the later period they were between Hezbollah and the Israelis or Hezbollah and its local political opponents.

If we were to look at the political demonstrations to show dissatisfaction with the regime as a last resort but stopping short of an all out coup d'état, it is significant that there were more political demonstrations in the five year period between 1970 and 1975 
than there were during the fifteen years of Syrian occupation. The same is true for the four-year period between 2005 and 2009.

The number of arrests is even more informative: there were no arrests made in the 2005 to 2009 period, while there were more than 130 arrests during the fifteen year occupation, mostly when the demonstrations were against the Syrian presence in the country or against the closure of a TV station by the Syrian controlled government.

The number of demonstrations from 1970 to 1975 was 381 with 869 victims and more than 155 arrests. These demonstrations were against the government and its incompetence in offering basic services, dealing with the cost of living and stopping or answering the Israeli attacks against the Southern part of the country. These demonstrations could also be explained by the nature of the Lebanese people and their short fuse and willingness to take to the streets to show dissatisfaction. One can compare them to the demonstrations and strikes that take place so often in France or in Italy for instance, two democratic countries. The number of demonstrations could also be significant when we look at it through the focus of the freedom of expression. From 1970 to 1975 Lebanon was considered a free and a democratic country by both Freedom House and Polity IV, so the number of demonstrations could be explained by the fact that demonstrations and public expression are guaranteed by the democratic regime. The same is true for the period starting in 2005 , when the country was slowly bouncing back towards democracy and political freedoms. 
During the Syrian occupation, demonstrations were discouraged and dealt with in a repressive manner: the number of arrests is a case in point: no arrests were made as a result of political demonstrations after February 2005, while there were more than 130 arrests from political demonstrations during the Syrian occupation. The number of victims in the third period, counting only those resulting from demonstrations, is eleven. The number becomes much higher if we were to count the clashes between supporters of the government and the opposition. It would become even higher if we added those resulting from clashes that Hezbollah ${ }^{6}$ militants had with political opponents, mostly Sunnis and the partisans of Prime Minister Saad Hariri. The fact that there is an armed militia in the country that does not abide by the established laws of the land is a serious threat to the democratic regime and is discussed further in the section on the challenges to democracy in Lebanon. The political party of Hezbollah, an armed resistance to the Israeli occupation of Lebanon, and a powerful presence in the government, had imposed its political demands through a sit-in in downtown Beirut that lasted over a year. Even though the sit-in was a peaceful event, would it fit under the description of Linz \& Stepan of behavior that happens in a consolidated democracy?

\section{The sit-in in downtown Beirut.}

To show protest against the present government, against the creation of the

\footnotetext{
${ }^{6}$ Hezbollah (or Hizballah), the Party of God, started as an armed movement formed by a Shiite Imam to call for and protect the rights of the disadvantaged Shiite community in the Lebanese society. It changed through time into a powerful, armed militia, seen as a resistance against the Israeli occupation of Lebanon. Currently it is a powerful political party, still armed heavily, with elected members in the Parliament and many cabinet ministers. It is supported financially and politically by Iran and Syria.
} 
International Tribunal for Lebanon through the United Nations to investigate the assassination of Prime Minister R. Hariri, Hezbollah and its allies staged a sit-in in the commercial center of the capital. It lasted a little over a year, caused major financial losses for the local businesses, ruin for some, and distress for the local economy. A survey done in late December 2006 and early January 2007 studied the attitude of the citizens towards the sit-in downtown. The survey was done by Statistics Lebanon and will be discussed further in the attitudinal section. Using the sit-in as a protest tool was faced with a wide variety of responses from those surveyed: $43.75 \%$ of those surveyed saw that the sit-in is an acceptable way to change the government as opposed to doing it through democratically elected institutions, while a close $41 \%$ did not see it as an acceptable method.

A survey taken 5 months later by Information International, showed a different attitude towards the sit-in and impatience with its unintended consequences of paralyzing the downtown area and financially hurting the businesses that operate in the center of Beirut. In May of 2007 more than half of the respondents (56.8\%) were against the sit-in. This survey will also be discussed in more details in the attitudinal section.

The sit-in came at a time when the pro-Syrian Speaker of the Parliament was refusing to call for a parliamentary session to allow for the institutions in place to play its intended role. The anger and dissatisfaction of the citizens with the sit-in included also impatience with the Speaker and with the fact that the Parliament was not permitted to be the scene of discussion and an arena for democracy, and for the elected officials to 
represent their constituencies. Those who were against the sit-in were calling for taking the struggle and disputes out of the streets and into its intended arena: the democratic institutions in place. The fact that the sit-in took place and that the Speaker of the Parliament, who belongs to the same political faction as those who organized the sit-in, refused to call the parliament into session, are two of the challenges facing the consolidation of democracy in Lebanon. Challenges that are at the same time a direct result of the nature of a Consociational democracy: when the tyranny of the majority is replaced by that of a minority, and consequently when the consensus is not possible, the end result is a paralysis of the entire system. This issue will be discussed further in the section about the challenges to the consolidation of democracy.

It is of interest to note how Freedom House looked at the sit-in: it considered it as a manifestation of the freedom of association rather than an ignoring of the institutions in place, i.e. the Parliament. In its 2009 report on Lebanon, Freedom House stated that "Rights to freedom of association and assembly are generally unrestricted. On several occasions in recent years, hundreds of thousands of Lebanese have rallied in favor of or in opposition to the government. A tent camp populated by opposition supporters remained in immediate proximity to the government's headquarters from December 2006 to May 2008."

For the behavioral variable then, we can conclude that even though the demonstrations lead to a number of victims, it is more meaningful to look at the number of arrests that resulted from the demonstrations. The fact that when the country was 
considered free by Freedom House and democratic by Polity IV, there were more demonstrations taking place but fewer arrests, if any. The demonstrations were more of a manifestation of the freedom of expression and of assembly. If we were to compare the numbers of arrests and victims from demonstrations that took place in the 1970 to 1975 and the 2005 to 2009 periods with those that took place during the Syrian occupation, we would find the following: though the occurrence of demonstrations was less frequent during the occupation, they were violently suppressed and led to a much larger number of arrests.

\section{The Attitudinal Variable}

Attitudinally, the democracy is consolidated when the majority holds the belief that no alternative to democracy is acceptable as a way of governing. According to Linz \& Stepan's definition, democracy is consolidated "when, even in the face of severe political and economic crises, the overwhelming majority of the people believe that any further political change must emerge from within the parameter of democratic formulas" (Linz \& Stepan, 1996: 5).

The earliest available surveys on this topic go back to 1995. They include studies that were done in the years of the Syrian occupation that lasted from 1990 to the $14^{\text {th }}$ of February, 2005, the date of the assassination of Prime Minister Rafik el-Hariri and the start of the resulting Cedar Revolution. The surveys done in that time period were done under an oppressive authoritarian regime. It is remarkable that the answers were frank in 
the sense that they were actually criticizing the regime and the system in place. It is also expected for the responses to show a perception of lack of democracy and dissatisfaction with the way the government is run. The Syrian authoritarian regime was in total control of the country's political machine and at the controls of the government. The people's attitude towards government under the Syrian occupation was the result of a restrictive regime and its controlling the mechanics of the government in place. The surveys used in this dissertation were either made public by the organization that conducted the study in line with their mission to educate the citizens, or they were made available at the organization's offices. To study the people's attitude towards democracy, a multitude of questions were asked, and each survey used questions that studied one or more of the different components of a democratic regime. These ranged from the freedoms guaranteed by a democracy to the accountability of those in government and the role of political parties. The surveys in the analysis will be listed according to the topic they addressed. The background and details for the data of these surveys are described in Appendix B. In the appendix they are listed in a chronological order rather than by topic.

A word of caution is that these were secondary sources, the only available sources going back to 1995 for the purpose of this study. Even though these were done by professional organizations and study centers, we would have to look at the results with the awareness of the fact that we had no control over the questions that were asked, the way the questions were phrased or how the surveys were administered. In a way it was 
fortunate to have been able to find surveys dating back to 1995, to be able to shed some light on the attitudes of the Lebanese towards democracy coming out of a long period of war. Also, at times, more than one survey done by different organisms came to the same conclusions . The fact remains however that these should be taken cautiously and used as a springboard for later, better controlled surveys. Another factor to consider is the danger of conducting these surveys in unstable conditions. It might be downright dangerous to ask questions about sensitive topics and expect reliable answers in hostile environments. The ones that are already available will serve as a starting point and a window into the past opening the way towards more controlled and current ones.

\section{The Surveys.}

These surveys show the Lebanese citizens' attitude towards democracy as the only acceptable regime for the country, despite some gaping holes in its application. The questions asked by the surveys studied the Lebanese attitudes towards one or more aspects of a democratic regime. These surveys addressed the following topics or questions:

- The freedoms associated with a democracy

- Do you consider the current regime a democracy?

- Would another regime be acceptable in the country?

- The role of the political parties and affiliation to the leader

- The accountability of the elected officials and transparency of government 
- The nature and value of the elections

- The civil society and political participation

- The constitution and constitutional amendments

- Political confessionalism in a Consociational democracy

- The presence of armed forces other than the Army

- Lebanon "is a final homeland for all its citizens" (Preamble to the Constitution)

The surveys will be listed and analyzed following the order of the topics listed above, starting with the way the Lebanese view the freedoms associated with a democratic regime.

The Lebanese attitude towards the freedoms associated with a democracy.

Marsad al-Democratiyah Fi Loubnan or The Democracy Watch in Lebanon, studied the "Importance of liberties in Lebanon, of political and civil rights," from February through September of 1998. This study was published in 2000, at the end of nine symposia run by the Joseph and Laure Moghaizel Foundation in cooperation with the European Union. The reports were published in Arabic under the title The Democracy Watch in Lebanon, Beirut, 2000 with Antoine Messarra as editor. Through face to face interviews, done between February and September of 1998, 496 randomly chosen men and women from all regions of Lebanon and from different demographics and socioeconomic backgrounds, were asked about the importance of liberties in Lebanon, political rights and civil rights. The respondents chose the freedoms they deemed most 
important, the results are shown in figures 1 and 2 below:

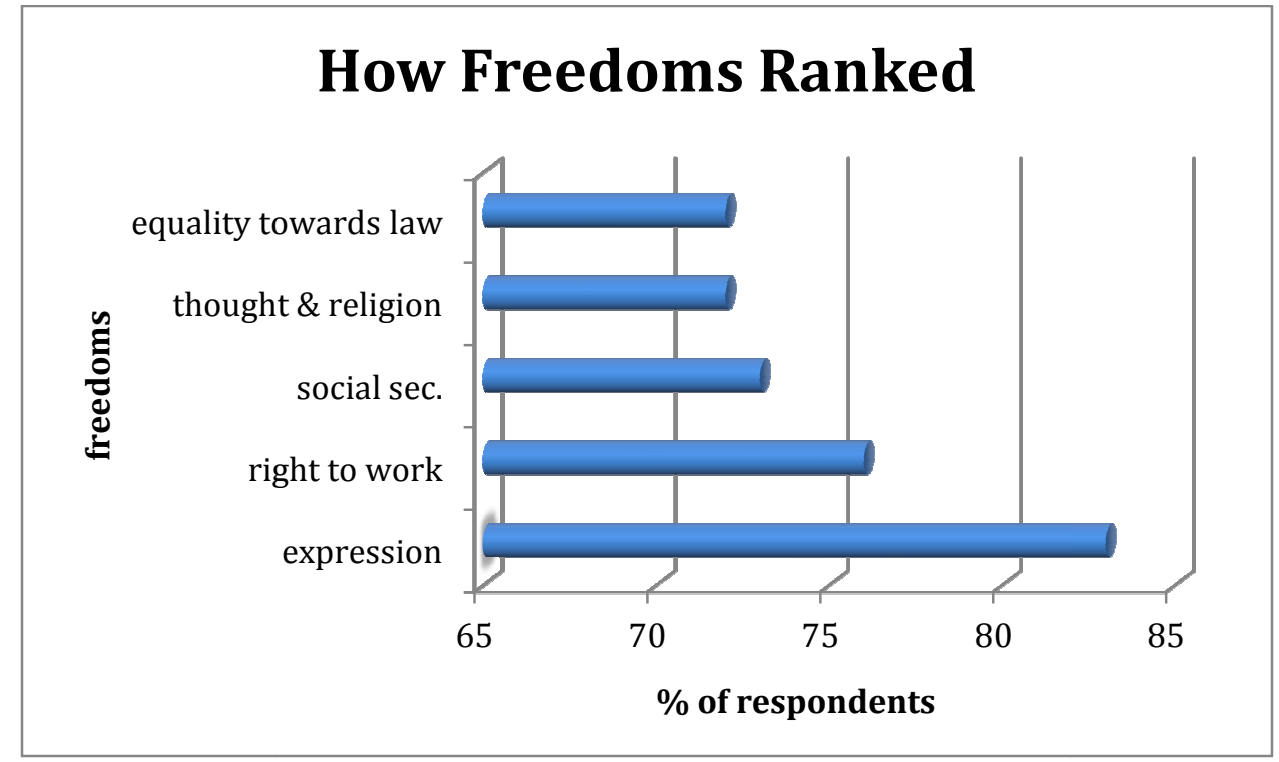

Figure 1: The importance in Lebanon of freedoms associated with democracy. Source: Democracy Watch in Lebanon, 1998.

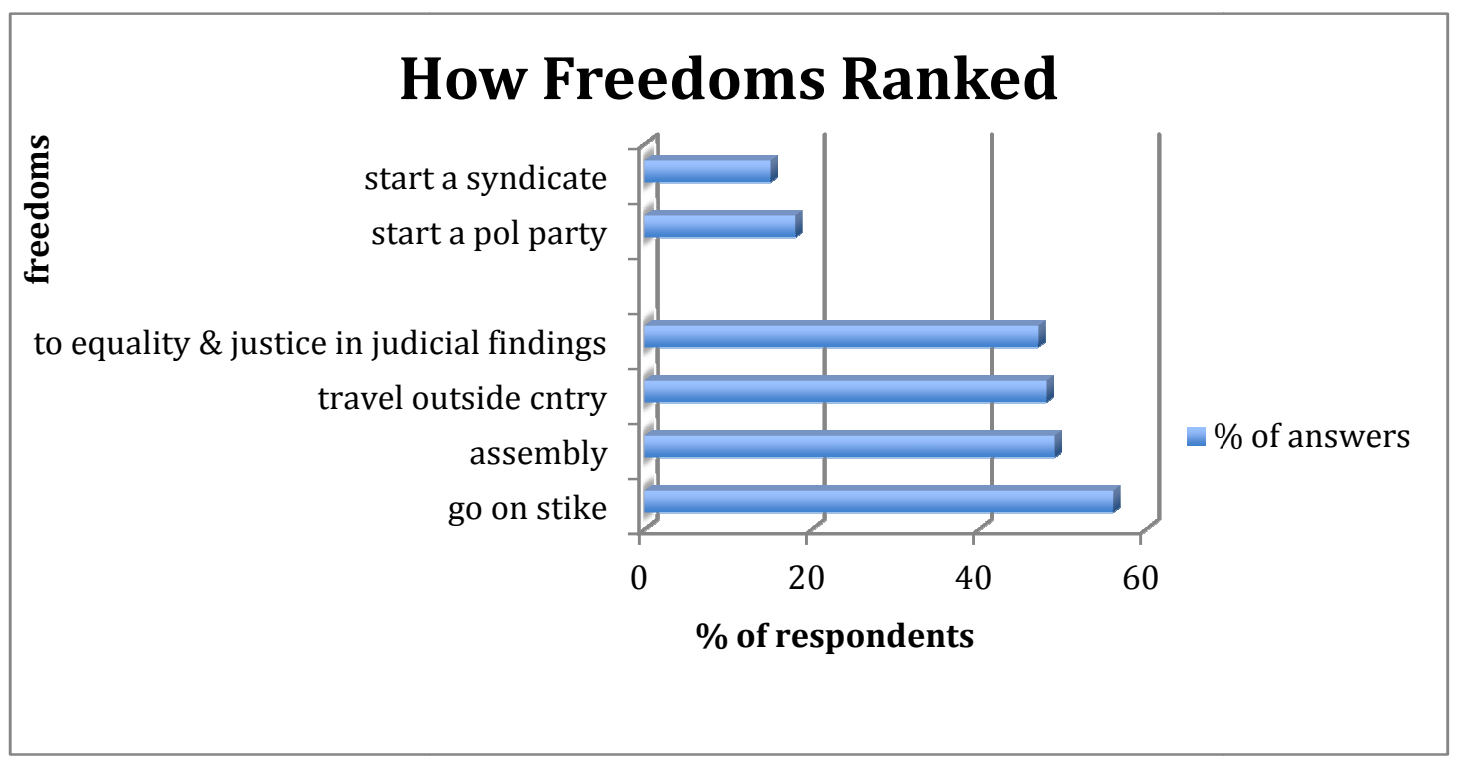

Figure 2: The importance in Lebanon of freedoms associated with democracy. Source: Democracy Watch in Lebanon, 1998.

For more details of the distribution of percentages among the different groups please 
refer to Appendix B.

This survey shows an overwhelming majority of the respondents considering the freedoms associated with democracy to be essential in Lebanon. In figure 1 we see for instance that close to $85 \%$ of the respondents said that the freedom of expression is the most important freedom associated with democracy. This importance that the Lebanese give to the liberties provided by democracy fits under the definition of the attitudinal component given by Linz \& Stepan, and within "the parameter of the democratic formulas" (Linz \& Stepan, 1996: 5).

Another survey done in December of 2000 by Information International addressed the freedom of expression in particular. It aimed at, among other topics, gauging the extent of the respondents' belief in the freedom of expression in the country. The survey was done in Beirut only. Asked whether there is freedom of expression in Lebanon, $60 \%$ of the respondents said yes, $29.1 \%$ said no, $2.7 \%$ did not know and $8.2 \%$ found that there is some form of freedom of expression. The respondents were from the capital distributed equally among the capital's neighborhoods with their different political leanings and religious affiliations. The highest percentages of "yes" respondents came from the Sunni neighborhoods (Msaitbeh $76.1 \%$ saying yes), and Shiite neighborhoods (Shiyah $70.1 \%$ ), while in the Christian neighborhoods the "yes" response rate ranged between a $46.3 \%$ and a $56.7 \%$ (for a combined average of 51.1\%). Figure 3 below illustrates the results of this survey. 


\section{Is There Freedom of Expression in the Country? Dec. 2000}

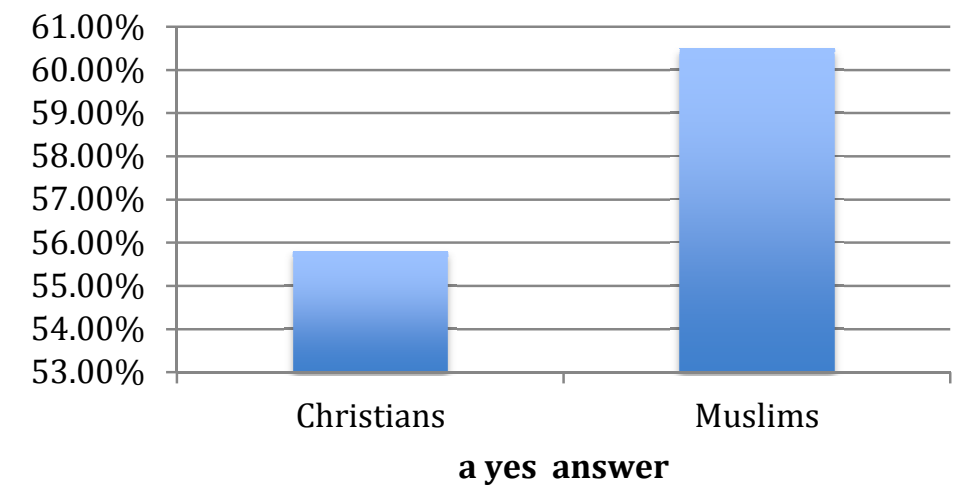

Figure 3. Is there freedom of expression in Lebanon?

Source: Information International, 2000.

In February 11-13, 2006, Statistics Lebanon conducted a survey to study, among other topics, the Lebanese attitude towards the freedom to demonstrate. It asked about the freedom of demonstration through direct interviewing of 400 respondents residing in Beirut, Mount Lebanon, the South, North and the Bekaa valley, divided equally by gender and with a variety of age groups, different social status and education levels. The results showed that $49.25 \%$ of the respondents are opposed to the decision by the government to ban demonstrations for the time being. This survey showed the displeasure of the Lebanese throughout the country with the pro-Syrian government's decision to ban public demonstrations. That ban is a direct threat to the freedom of expression and the freedom of assembly guaranteed by the Lebanese Constitution. 
From the surveys listed above, we see that a majority of the respondents believe in the importance of the freedoms associated with democracy. The 1998 series of symposia run by the Democracy Watch in Lebanon highlighted the importance the Lebanese attach to political and civil rights. It strongly shows the deep belief the Lebanese have in the importance of political and civil freedoms, and the strong culture of democracy prevalent in the country. That remained true even when they were under occupation by an authoritarian regime.

The survey done in 2000 by Information International in Beirut, about the existence of the freedom of expression, showed that a majority of the Muslim respondents $(76.1 \%$ Sunnis and $70.1 \%$ Shiites) saw that there is some form of freedom of expression, while an average of $51.1 \%$ of the Christian respondents agreed with that statement. The Christians' attitude could go back to the history of random arrests and investigations by the security forces and the Syrian services against the Christian population, especially those who declared anti-Syrian views. That fact could explain the negative responses of the Christians to the Information International survey.

It is also important to note that, on the one hand, the Democracy Watch study showed the importance the Lebanese attach to the liberties associated with a democratic regime, on the other hand, and in practice, they do acknowledge that the freedom of expression is lacking and so is the freedom to demonstrate under the Syrian occupation.

The issue of gender equality was addressed in one of the major studies that will be detailed a little later in this section. It is a poll done between June of 2006 and April of 
2008 by the Lebanese Opinion Advisory Committee, the International Republican Institute, and Statistics Lebanon, and it showed the importance the Lebanese attach, in all their factions, to equality: $75.9 \%$ of those surveyed were in favor of the presence of women as cabinet ministers. Another survey mentioned later in this section, done by Information International and published in the December 2004 issue of iMonthly had the same result: more than $75 \%$ of the respondents were in favor of the presence of female cabinet ministers in the government. A third survey done by the University of Jordan and Statistics Lebanon in November of 2007, found that the Lebanese, across religious lines, agree or strongly agree that a woman could be a prime minister or a president of a Muslim nation, and that women and men should receive equal opportunity for the same work.

These surveys then show the importance the Lebanese attach to the freedoms afforded by a democratic regime and resulting from a "culture of democracy" as Daniel Hanna described it in a Lebanese television broadcast in 2008. So then, how do the Lebanese perceive the regime in place, do they see it as democratic?

\section{The current system in place.}

In October of 1997, Information International conducted a study entitled "Political life, performance of the government and of the politicians." The study was published in three parts: Political Life in Lebanon, Performance of the Government and of Politicians, and The Three Presidencies and the Deputies of the Five Mohafazats 
(counties). The samples were taken randomly from the major cities and all religious factions in all five mohafazats of the country, with a larger number taken in Beirut because of the higher population density. The first question asked if there was a democratic political life in Lebanon; over half (57.9\%) of the respondents answered negatively, while $42.1 \%$ of them saw that Lebanon is a democratic state. Of the $57.9 \%$ : $33.9 \%$ saw that government is controlled by a mafia of rulers, while $25.1 \%$ saw that it is not democratic because they lack the freedom to express their opinion; $21.4 \%$ saw that it is not democratic as a result of foreign interferences, and $11.1 \%$ saw that those in power do not listen to the people. $5.3 \%$ of these respondents did not know the cause of the lack of democracy, and $3.2 \%$ saw that it is a result of confessionalism.

This same survey was mentioned in the earlier section about the freedoms associated with a democratic regime. The interpretation of the same answers could also be helpful to see if the respondents believe the regime to be democratic. We should also keep in mind the dates of the survey and the circumstances under which it was done: in October of 1997 Lebanon was still under the occupation of the Syrian authoritarian regime.

Asked whether there is true opposition in the Lebanese political system, $45.7 \%$ saw that political opposition does exist while $53.5 \%$ saw that there is no opposition in the true sense of the word, but that it is simply a superficial opposition that exists mostly for appearances or to satisfy personal aspirations. There was no significant difference among the respondents to this question by gender; males and females were roughly equally 
divided in their responses. However, there were considerable differences along the religious lines in the response to the question about whether or not there is a democratic political life in Lebanon: $60.5 \%$ of the Christians saw that there is no democracy in the country, compared with $55.8 \%$ of the Muslim respondents. As for the existence of a true opposition, $44.3 \%$ of the Christians saw that there is no true opposition, compared with $61 \%$ of the Muslim respondents as illustrated in figure 4 below.

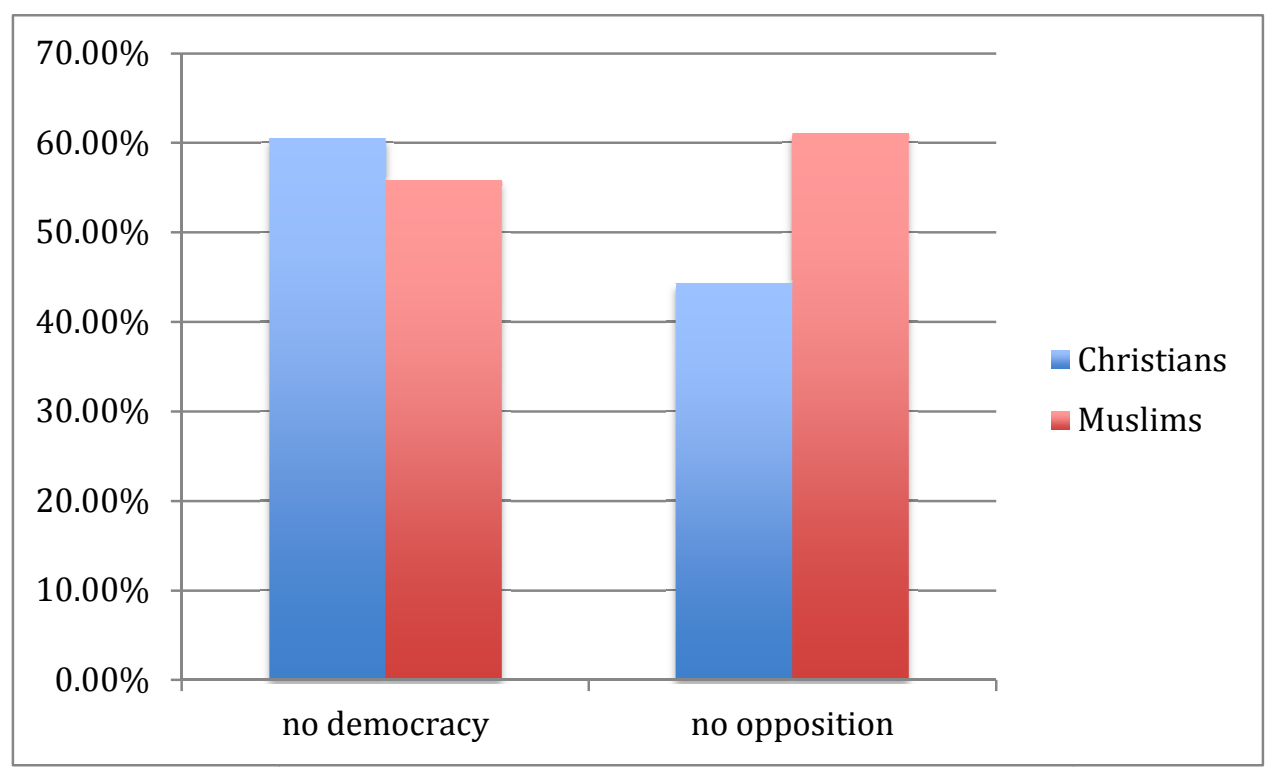

Figure 4. Is there democracy in Lebanon? Is there a true opposition? Source: Information International, 1997.

It is important to note that among the religious groups surveyed there were large discrepancies between their answers along religious lines: $88.5 \%$ of the Roman Catholics respondents, $74.6 \%$ of the Shiites, $67.6 \%$ of the Maronites, $49.7 \%$ of the Sunnis, $47.1 \%$ of the Greek Orthodox, $45 \%$ of the Alaouites, $43.6 \%$ of the Druze, and $21.7 \%$ of the 
Protestants saw that there is no democratic political life in Lebanon.

As for the existence of a true opposition group, the highest percentage of those who do not see that there is opposition comes from among the Druze respondents (67.3\%), followed by the Sunnis $64.8 \%$ and then the Shiites $52.1 \%, 50 \%$ of the Roman Catholics and the Alaouites respondents, and then $47.8 \%$ of the Protestants and $44.5 \%$ of the Orthodox. The Maronites had the lowest percentage, at $43.3 \%$ not finding a true and efficient political opposition group. (Figure 5 below)

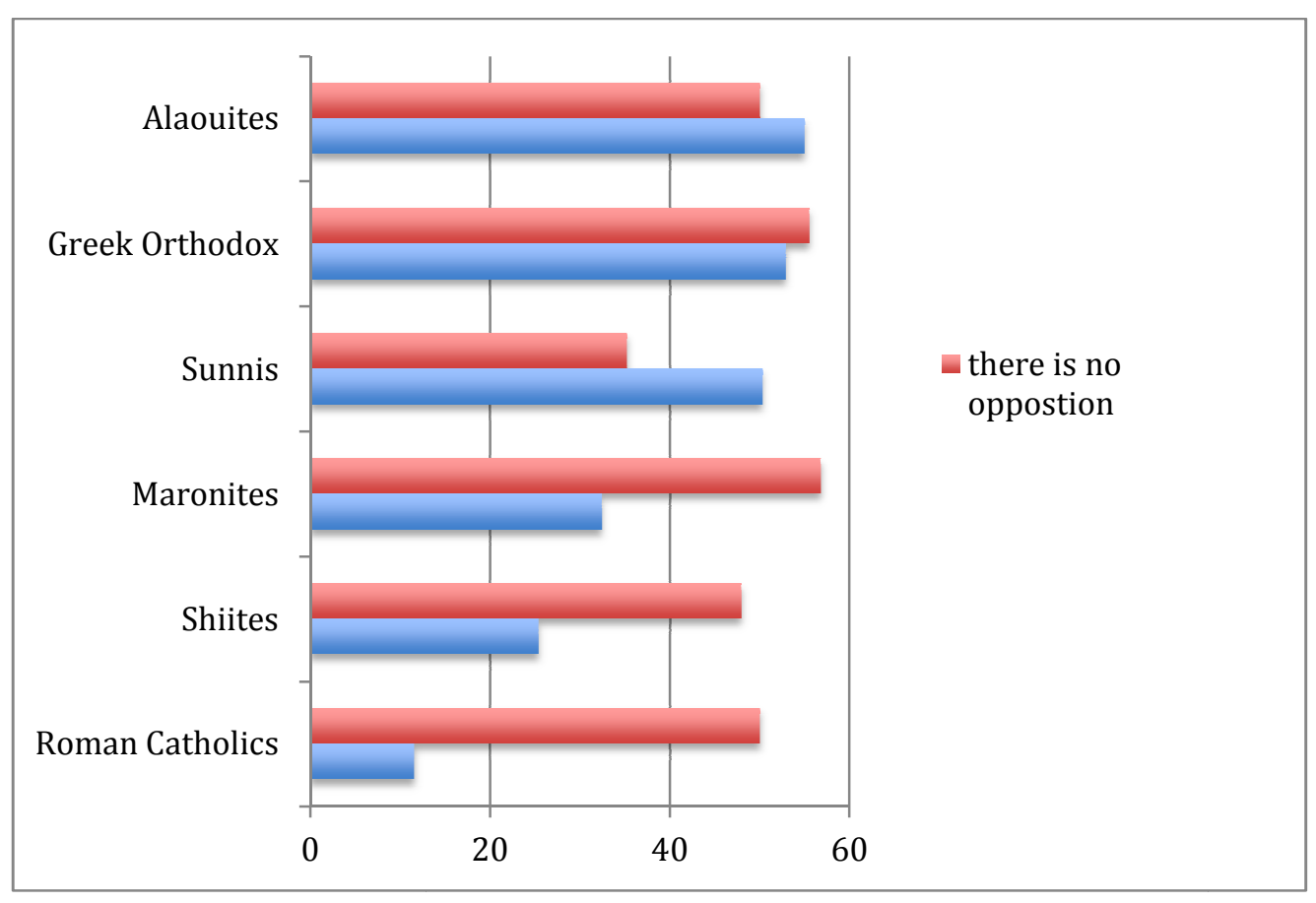

Figure 5: How different religious rites look at opposition and at democracy in the count Source: Information International, 1997.

There were marked differences also along regional lines, with those living in Beirut (74.7\%) and the Mount Lebanon (75.1\%) areas having the highest percentage of those who do not see the political life as democratic enough with the lowest percentage 
$(32.2 \%)$ in the Bekaa valley region.

As for the regional distribution of the responses to the existence of a true political opposition, the highest percentage of respondents denying the existence of a political opposition came from the South (72\%), a region from which come both the Prime minister and the Speaker of the parliament at the time.

Distributed by age, the survey showed the majority of the younger generations not believing in the presence of a true opposition. The large majority of the respondents with the highest income believed that there is no democratic political life in Lebanon. As for the education factor: the higher the education levels the less likely the respondents were to find the political life as democratic (Figure 6).

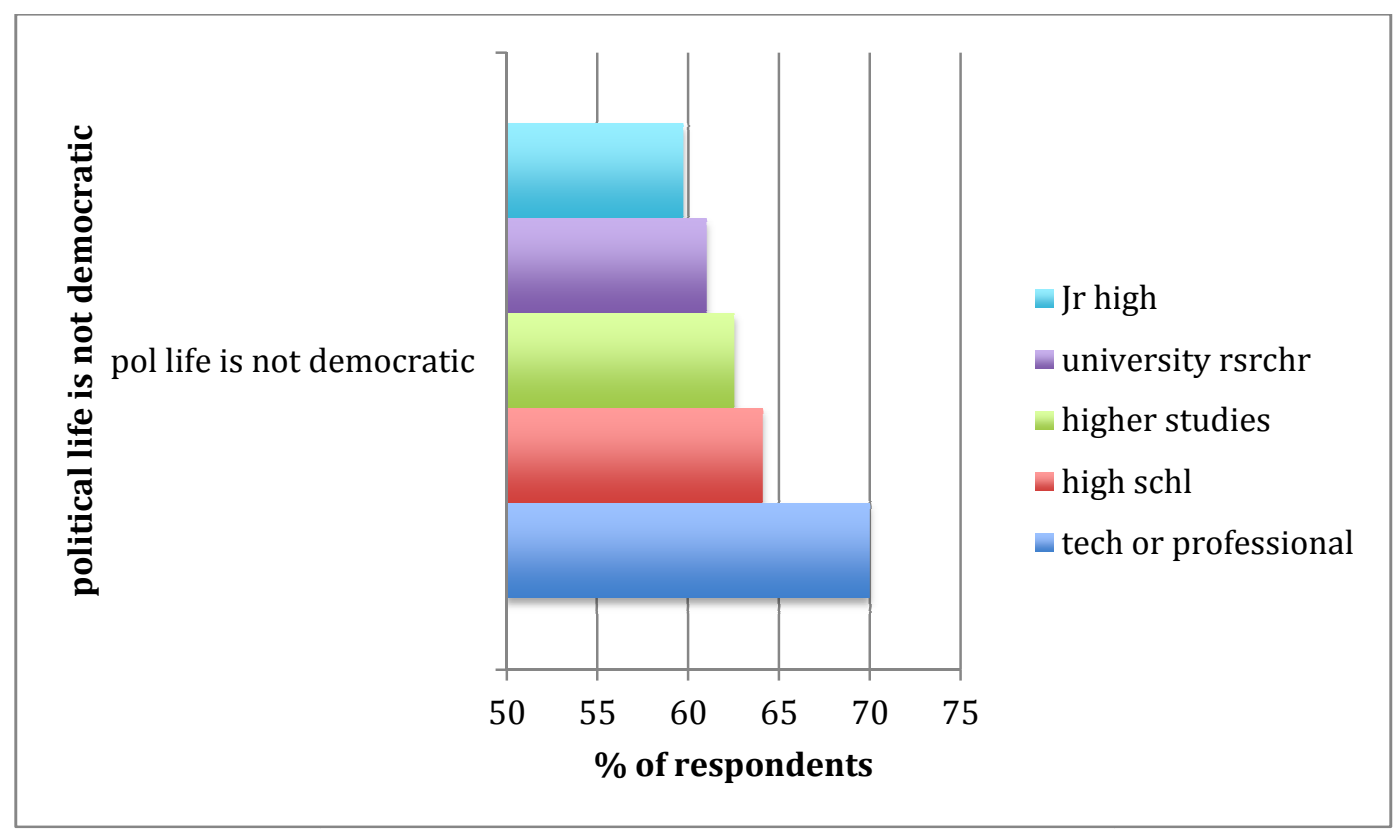

Figure 6: Is political life democratic? Respondents grouped by education level Source: Information International, 1997. 
This survey also asked about the attitude of the respondents towards renewing the mandate of the president (which does not conform to the Constitutional dictates): Over half of the respondents $(56.8 \%)$ refused the renewal of the President's mandate (Information International, October 1997).

The 1997 study done by Information International revealed a realistic view of the system in place in Lebanon during the Syrian occupation: the majority of the respondents did not see the current political life as democratic, that the government is controlled by a "mafia of rulers," and that there is "no true opposition." It is worth noting that the higher the education level the less likely they are to find the political life as democratic during the Syrian occupation: $70 \%$ of those carrying a higher diploma compared to $47.4 \%$ of those with an elementary education found political life non-democratic.

\section{Would a regime other than democracy be acceptable in the country?}

In continuing with the list of topics that address the Lebanese attitude towards democracy, the following surveys tried to see if the Lebanese do consider democracy as the only game in town.

In September of 2001 Information International conducted an opinion poll on government performance after 200 days of the government's being in place, and then again after 300 days. One question asked about the accountability of the government and to whom it should answer. In the 200 days poll the results showed that the majority 
of the respondents see that government is accountable towards the parliament. (Figure 7)

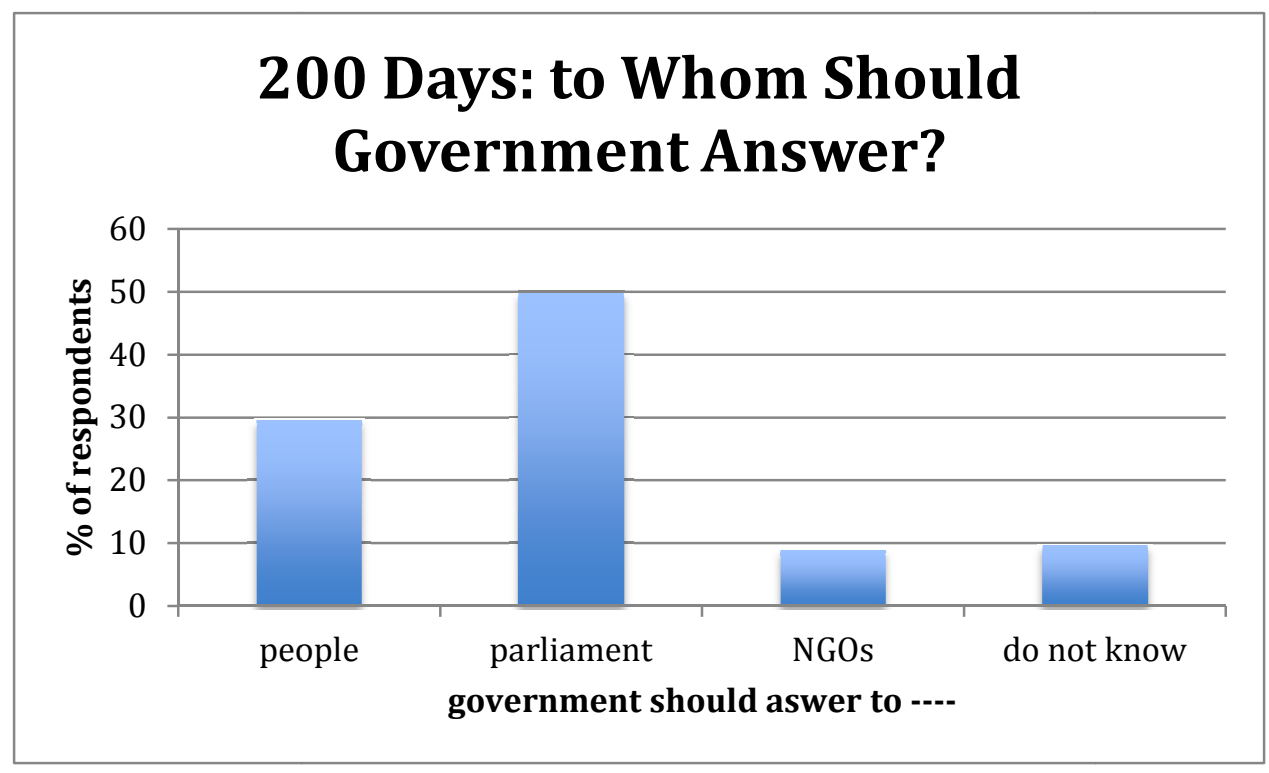

Figure 7. To whom should the government answer?

Source: Information International 2001

When the same poll was repeated after 300 days of the government being in power, $37.4 \%$ of the respondents said the government is responsible to the parliament, $44.4 \%$ said to the people, $10.2 \%$ did not know and $7.2 \%$ said the government should answer to NGOs (Figure 8). Only in a democratic regime does the government answer to the people who elected them into power. 


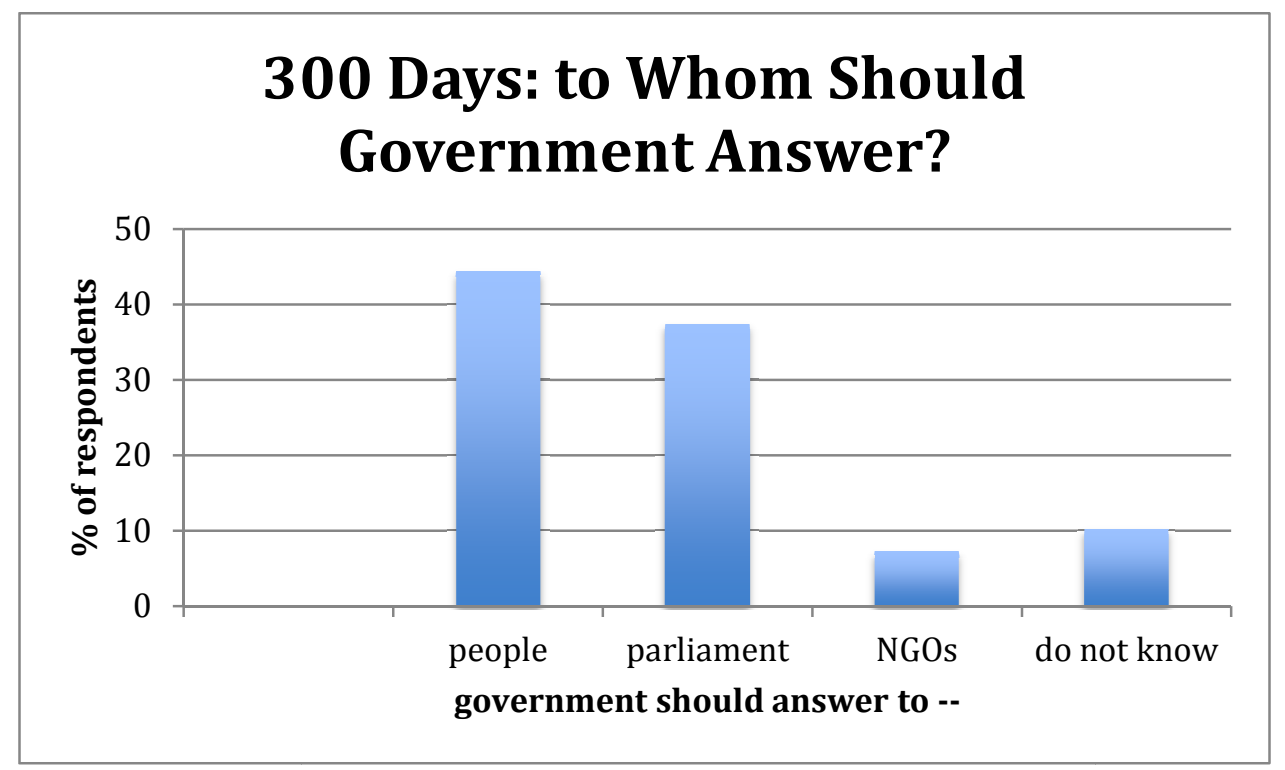

Figure 8: To whom should the government answer? 300 days into the term of the current government.

Source: Information International, 2001.

Another question from the September 2001 Information International survey that is relevant to our topic, asked the respondents if they agreed on the establishment of a military government. $77.7 \%$ said No, $11.0 \%$ said Yes, $8.6 \%$ did not know, and $2.7 \%$ were not concerned. Broken into confessions, $71 \%$ of the Maronites refused the possibility of a military government, $73.7 \%$ of Greek Orthodox, $88.6 \%$ of Roman Catholics, $85 \%$ of Sunnis, $75.9 \%$ of Shiites, and $77.3 \%$ of Druze. (Figure 9) 


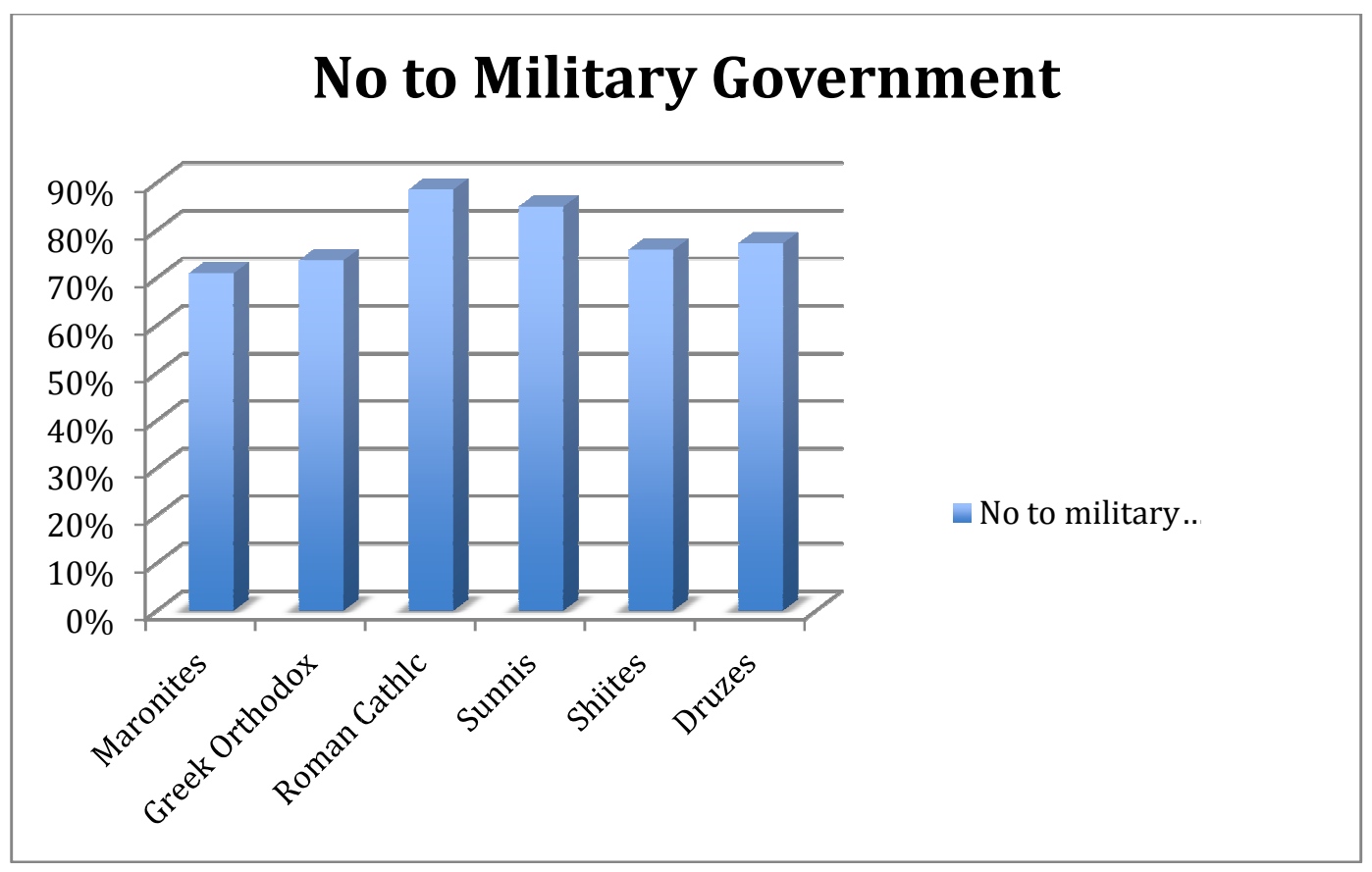

Figure 9 : A military government is not acceptable, by religious rites. Source: Information International, 2001.

In April of 2003 another Information International study polled the Lebanese about what they thought of the 15-year war and its purpose. The survey was published in An-Nahar newspaper on April 22, 2003. On the anniversary of the start of the Lebanese war, April 13, a sample of 600 Lebanese citizens in the greater Beirut area were asked about the causes and results of the war and the Taef accord. The results showed that only $10.2 \%$ of the respondents believe that the war accomplished the purpose for which it was started; $87.7 \%$ believed that it did not accomplish any of its goals ${ }^{7}$, whatever these

${ }^{7}$ In the survey, the "goals" were never described in a clear fashion. These goals are still a contentious subject among the Lebanese and are seen differently depending on the faction. The Christians mostly see it as a way to recapture the country from the outsiders and especially the armed Palestinian refugees in the country. The Shiites see it as a way to acquire social justice and equality. The Druze and the Sunnis have their own goals too. Even though the different factions see 
were. (Figure 10)

These results were not influenced by the religious affiliation of the respondents.

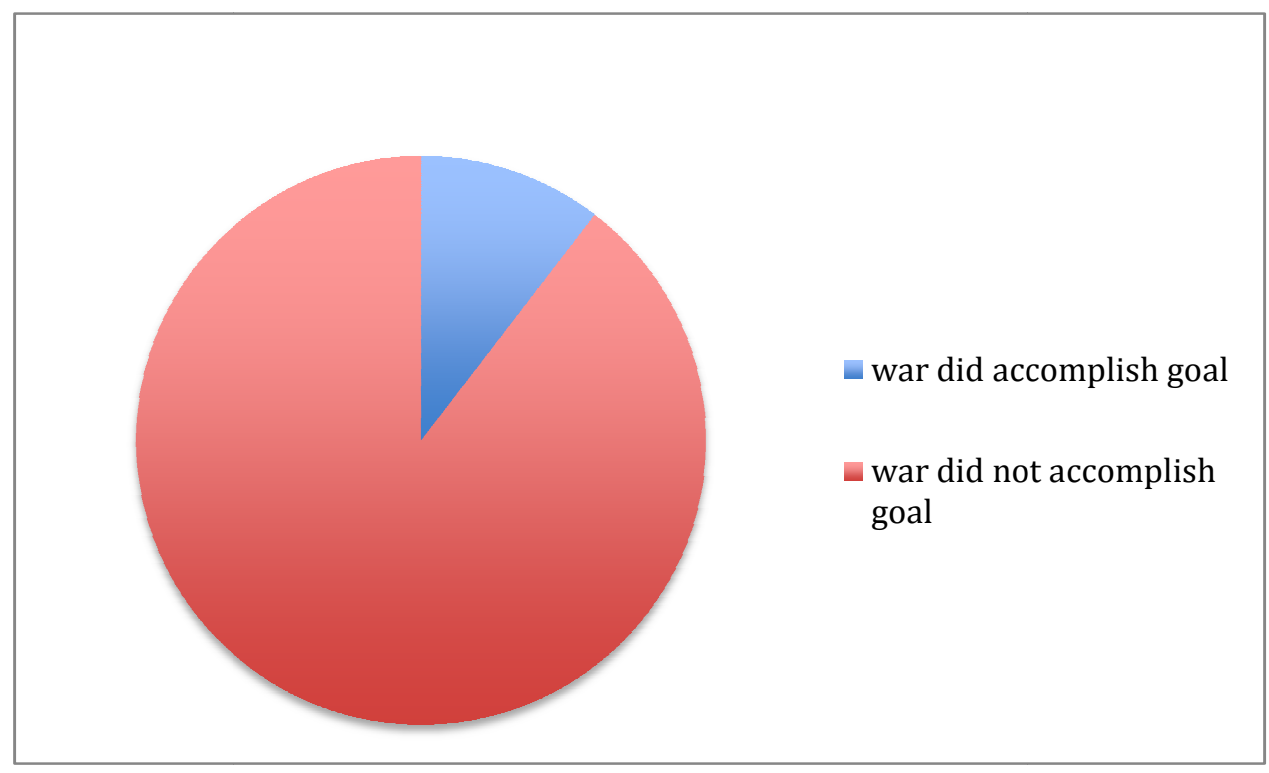

Figure 10: Did the 1975-1990 war accomplish its goal ${ }^{7}$ ?

Source: Information International, 2003.

$49 \%$ of those surveyed suffered damages from the war; $32 \%$ lost their homes; $44.5 \%$ were for bringing to justice the leaders of the different militias and political parties that participated in the war; $37.8 \%$ believed that the Taef accord brought a short temporary end to the war, while $32.5 \%$ believed that it brought a long temporary end.

The results from the above mentioned surveys all have elements that fit under the

the war differently and its goals vary from one faction to the other, the majority agreed, however, on the fact that the war did not after all achieve any of what it was fought for. 
definition we are following for the attitudinal component of a consolidated democracy, where "the overwhelming majority of the people believe that any further political change must emerge from within the parameter of democratic formulas" (Linz \& Stepan, 1996: 5). Considering the government as accountable to the people is a clear indicator of an attitude used to the mechanics and workings of a democratic system, where those in power still have to answer to the people they represent.

A 2005 Zogby International survey done in several Arab countries, including Lebanon, studied the citizens' attitude towards democracy. It was done through face-toface interviews with six hundred randomly selected citizens in each country. The study was commissioned by the Center for Democracy and the Rule of Law. Of the questions asked, three are of interest for the purpose of this thesis to test the Lebanese attitude towards democracy:

- Do you identify with the Lebanese identity first or with the religious identity first?

- Do you conceive a political regime in Lebanon other than democracy?

- Do you trust an elected Islamic government to follow the rules of democracy?

The majority of the respondents in Lebanon identify with the Lebanese identity first. This result is echoed by a similar question asked in the 2007 Springhints -Mind the Gap survey, which will be discussed further below. Also a majority of the respondents in Lebanon did not see a regime in Lebanon other than democracy. Christians in Lebanon were most skeptical about an Islamic government in the country: 
just one in five said they believe an Islamic government would abide by the laws of a democracy.

A report done in November of 2007, by the University of Jordan in collaboration with Statistics Lebanon, as part of the Arab Barometer Survey Project and which took place in several Arab countries, showed the Lebanese attitude towards democracy, citizenship and the democratic institutions. It revealed that a large majority of the Lebanese $(89 \%)$ consider democracy to be better than any other form of government, that over $72 \%$ do not see any justifications to abuse human rights for the sake of security, and that over $79 \%$ see that a parliamentary system of different political parties is an appropriate political system for the country.

From December 29, 2006 to January 2, 2007 Statistics Lebanon surveyed the Lebanese attitude about the sit-in in the downtown area. The sit-in was organized as a form of political protest against the government. The survey used direct personal interviews and cluster sampling from a sample of 400 respondents residing in various areas of Lebanon and comprised of an equal number from both genders and a variety of age groups made up of a variety of income and educational levels and sects. Asked about the demonstrations and sit-in in the downtown area to show opposition to the government, the responses showed that 33\% strongly supported the sit-in, $29.75 \%$ strongly opposed, $18.5 \%$ opposed, and $0.75 \%$ refused to respond (51\% supported and $48.25 \%$ opposed the sit-in). Asked if taking to the streets was an acceptable way to change a regime "as opposed to doing it through democratically elected institutions, 
$43.75 \%$ answered affirmatively, $41 \%$ answered negatively, $13.25 \%$ answered 'I don't know', and 2\% refused to respond."

A few months later in May of 2007, another agency, Information International, conducted an opinion poll about the still ongoing sit-in. It showed the Lebanese losing their patience and becoming less supportive of the sit-in. In the Statistics Lebanon survey, the majority of the respondents were for the sit-in in the downtown area as a sign of protest against the government. In the Information International survey, five months later, the results seem to show a different attitude among the respondents towards the sitin. The Information International survey was conducted between May 7 and May 14, 2007. The survey was published in issue 60 of iMonthly, the printed voice of Information International. The opinion poll was conducted on a sample of 1000 citizens in different Lebanese areas. The poll had the following results:

More than half $(56.8 \%)$ of the respondents were against the sit-in in the downtown area. It is important to note that the majority of the Shiite respondents $(77.5 \%)$ were for the sit-in with only $18 \%$ of the Shiites being against it. $87.25 \%$ of the Druze respondents were against the sit-in, $87 \%$ of the Sunnis, and $65.2 \%$ of the Maronites. This later survey showed a different attitude towards the sit-in and impatience with its unintended result. It paralyzed the downtown area and financially hurt the businesses that operate in that neighborhood.

These two surveys, in addition to addressing the attitude of the citizens towards democracy, are also useful in illustrating the behavioral variable of this study. The sit-in 
shows citizens acting in a way that fits under the dictates of the laws and aiming at resolving conflicts in a manner that eschews violence. It should also be mentioned that the sit-in could have led to the army or the police members forcibly and violently removing the protesters from the capital. The freedoms of demonstration and of expression were respected by the armed forces and those who control them. The fact that the sit-in lost the sympathy and understanding of the majority of the citizens after a while but without their resorting to violence, speaks a lot to the democratic habits of the Lebanese. These surveys not only show the attitude of the Lebanese towards a democratic regime, but they also address a behavior that illustrates how the Lebanese move towards resolving a conflict within the confines of the established laws, and according to the established norms. The Constitutional component is also illustrated in this example where the conflicts are "resolved within the dictates of laws, procedures and institutions established in a mutually agreed upon process " (Linz \& Stepan, 1996: $6)$.

From June 2006 to April 2008, The Lebanese Opinion Advisory Committee (LOAC) in a collaborative effort with the International Republican Institute (IRI), and Statistics Lebanon studied the "Attitudes Towards the National Identity, Voting and Democratic Institutions." This study was done through a series of opinion polls over a period of time extending from June 2006 to April 2008. The polls examined the "Lebanese Public Perceptions and Attitudes towards the National Identity, Voting and Democratic Institutions," as expressed by the title of the study. 
The first opinion poll of the series took place during the period from June 14 to July 10 of 2006. It was conducted shortly before the Israeli - Hezbollah war in 2006. It focused "on public perceptions of the Lebanese national identity, voting and democratic institutions." The sample was of 2400 respondents distributed geographically across the country in urban and rural areas, and among different socio-economic groups. The survey, conducted door to door, found that the Lebanese "express firm national allegiance, viewing themselves primarily as Lebanese and secondarily as a member of a sect or a religion." It also had the following results:

\begin{tabular}{|l|l|}
\hline The Lebanese see themselves as Lebanese first and members of their & $75.7 \%$ \\
\hline religious sect second & $94.4 \%$ \\
\hline "voting is a duty for every citizen who has the right to vote" & $79.1 \%$ \\
\hline "the voting process can change reality" purpose of voting is to select the right people to rule Lebanon, & $85.4 \%$ \\
regardless of their political party or sect" & \\
\hline support a "democratic government and reject the idea that extenuating \\
circumstances would justify a non-democratic government"
\end{tabular}

Table 1. Lebanese Attitudes towards National Identity, Voting and Democratic Institutions. Source: LOAC, IRI and Statistics Lebanon, July 2006. 
"A majority of the respondents support the Taef Agreement, which states that Muslims and Christians should receive an equal number of the 128 seats in the Parliament."

Other notable results:

- $91.4 \%$ of the respondents consider participation in the elections to be a way to "improve the future."

- $62 \%$ of the respondents "prefer voting for candidates representing political parties or groups."

- $80 \%$ said they would ultimately make their own decisions when voting rather than follow the directives of the religious leader.

- Shiites are the most likely group to follow the instructions of their religious leader, $44.2 \%$ of the Shiites said they would consider it as "their duty to follow a religious order, compared with $12.8 \%$ of Sunnis, $12.6 \%$ of Christians, and $9.9 \%$ of the Druze." This last finding is illustrated in figure 11: 


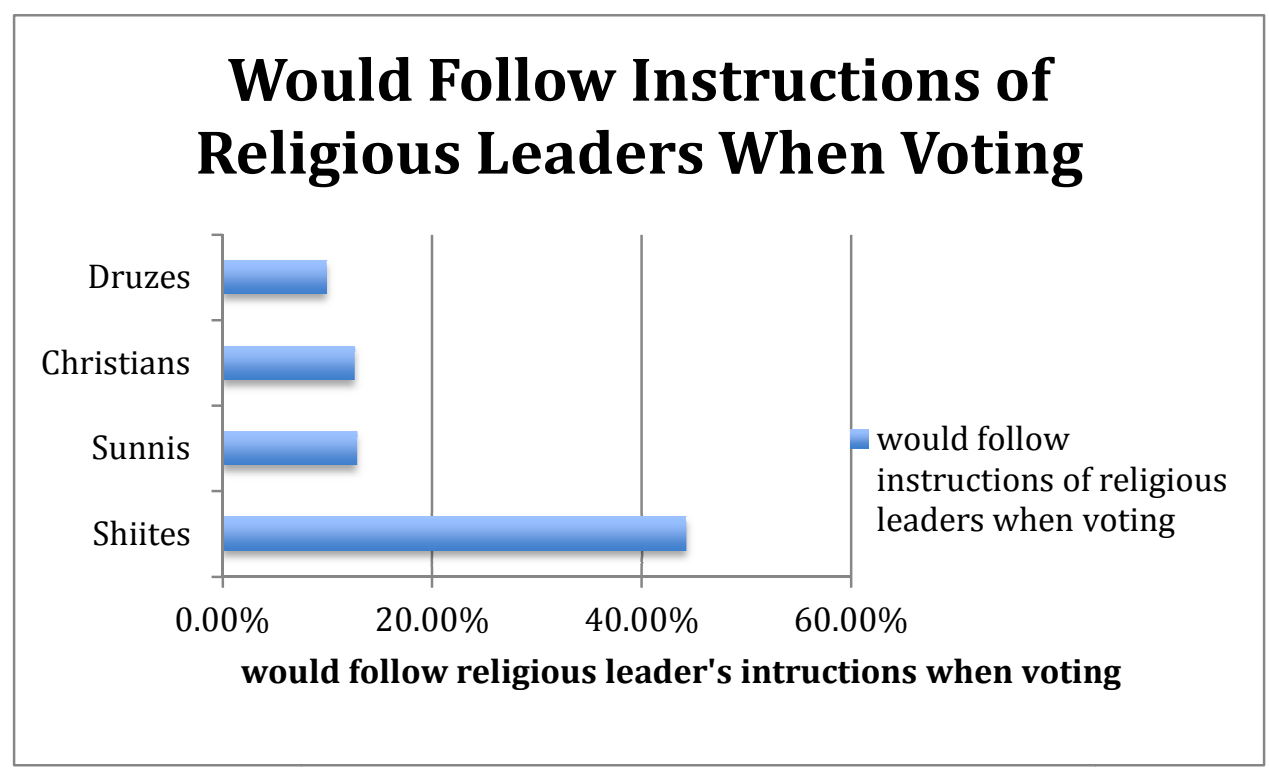

Figure 11: Would follow voting instructions from religious leaders, along religious rites. Source: LOAC, IRI and Statistics Lebanon, July 2006.

This survey shows the importance the Lebanese attach to voting as a part of a system that allows them to share in the decision making process, to cause changes and to be equal and active members of a society where only democracy is an acceptable form of governing.

These results were confirmed by another survey conducted between November 15 and December 11, of 2006 also by the IRI, the LOAC and Statistics Lebanon. This one looked at the "Perceptions of Politics, Leadership, and Current Events in Lebanon." The same methods were used as in the previous study, and it found a "high degree of nationalism and a strong belief in the importance of voting and the democratic process." A clear majority $(86 \%)$ of the respondents, "from all regions and sects opt for nonviolent, democratic and legal means of achieving their political ends." $13 \%$ said "they 
would participate in potentially violent demonstrations in order to achieve their objectives."

The third survey in this series was conducted in 2007 and it was another collaborative effort between the IRI, the LOAC and Statistics Lebanon. It was conducted between May 14 and June 11. It looked at "Perceptions of Politics, Leadership and Current Events in Lebanon," with the following results:

\begin{tabular}{|c|c|}
\hline $71 \%$ & $\begin{array}{l}\text { claimed they were 'Lebanese first, member of a religious group } \\
\text { second' }\end{array}$ \\
\hline $57 \%$ & $\begin{array}{l}\text { believe that the solution to the current political crisis can be } \\
\text { achieved through peaceful means }\end{array}$ \\
\hline $29 \%$ & $\begin{array}{l}\text { fear that the solution will come through some degree of } \\
\text { violence }\end{array}$ \\
\hline $14 \%$ & think the solution will lead to or result in open armed conflict \\
\hline $35 \%$ & $\begin{array}{l}\text { see that the primary cause of the current conflict and the sit-in } \\
\text { in downtown Beirut is a result of an "international and regional } \\
\text { conflicts" }\end{array}$ \\
\hline $70 \%$ & $\begin{array}{l}\text { support the current "arrangement of equal representation } \\
\text { between Christians and Muslims, put in place after the Taef } \\
\text { Accord. }\end{array}$ \\
\hline
\end{tabular}

Table 2. Lebanese perceptions of politics, leadership, and current events in the country. Source: LOAC, IRI, and Statistics Lebanon, 2007. 
This series of polls conducted by the IRI, the LOAC and Statistics Lebanon, between June 2006 and April 2008, show "strong belief in democracy and voting among the Lebanese, particularly as preferable to autocratic or theocratic alternatives." The majority of the Lebanese ( $86 \%$ of the respondents) opt for non-violent, democratic and legal means of achieving their political ends. The survey also found a high degree of nationalism and a strong belief in the importance of voting and the democratic process. Although most of the respondents did not belong to a political party and do not plan on joining one in the future, they do believe in the positive impact non-governmental organizations have on public policy in Lebanon.

In August 9, 2006, the An-Nahar newspaper published a survey in its annex Nahar el-Shabab. In cooperation with the YMCA, the International Association for Administration and Training, and the Colloquium for Parliamentary Dialogue conducted a survey about the "Definition of Democracy and Sources of Information". The survey showed that $90 \%$ of the respondents knew the definition of democracy as the rule of the people by the people. These respondents who knew the definition had at least a high school education and came from all social ranks. Those who could not give a correct definition of democracy were either illiterate or with an elementary level education.

Other than education, another source of information is the media: those between 33 and 39 years of age, $59.3 \%$ get their information from the media, with $53.8 \%$ of those doing so under 18 years of age. Asked if they had practiced democracy in one way or 
another:

\begin{tabular}{|l|l|}
\hline $98.4 \%$ & Of those over 47 yrs of age answered affirmatively \\
\hline $92.4 \%$ & Of post-graduates answered affirmatively \\
\hline $50 \%$ & Of young people polled saw that joining a political party is a \\
& road to leadership \\
\hline $94.8 \%$ & of those surveyed respect others' opinions \\
\hline $1.8 \%$ & believe in using force to impose their opinions. \\
\hline
\end{tabular}

Table 3. Do the Lebanese practice democracy?

Source: An-Nahar (Aug 9, 2006)

This survey shows the importance the Lebanese attach to democracy: the large majority has participated in democracy, knows what it means, respects others' opinion, and does not believe in using force to impose theirs.

In their 2001 survey about government performance 200 days and then 300 days into the current government's mandate, Information International asked about the possibility of a military government and if it would be the answer to a better performance and better security. The answer was a resounding "No" from all segments of society that were asked $(88.6 \%$ of the Roman Catholics, $85 \%$ of the Sunnis, and $75.9 \%$ of the Shiites refused the option of a military government). 
Another issue that the regime in Lebanon is facing as a result of its make-up and of its location in the Arab world with its overwhelming Muslim majority, is how to protect the democratic regime from falling to Islamization ${ }^{8}$. They sometimes get misinterpreted and pushed to extremes, which results in abuses and discriminations. In the 2005 Zogby International poll conducted in several Arab countries, including Lebanon, only $36 \%$ of the Lebanese respondents agreed with the claim that an Islamic government would follow the rules of democracy. The respondents included Lebanese Christians and Muslims. Another survey, Springhints - Mind the Gap, also showed a majority of the respondents rejecting the idea of an Islamization of the country's laws by "impregnating "the Lebanese Constitution with Koranic laws. The Islamization was not seen as a possibility by the respondents who were aged between 18 and 30 years. On the other hand the University of Jordan / Statistics Lebanon report saw that the respondents for their majority (around 56\%) do see the possibility of a democratic regime while remaining compatible with Islam, rather than falling prey to it.

In conclusion to this sub-section of the surveys, the question at hand, whether a regime other than democracy, is acceptable in the country, it was clear that the majority of the Lebanese do not see another regime as an acceptable option. A military regime is unappealing to them, and so an Islamic Shari'a regime. Voting and peaceful resolution of conflicts are the preferred methods. Being informed and involved in the current affairs of governing and voting is another way of participating in the democratic regime.

${ }^{8}$ Islamization is when the laws for daily life spelled out by the Koran are considered the laws of the land. 
Since democracy co-exists with conflict, it necessitates and even breeds conflict, but it is also built on means of conflict resolution that put a large emphasis on the process, on the participation of elites and non-elites alike in making decisions and finding compromises. The role political parties play in this process is essential. The following section addresses the Lebanese attitude toward this important component of a democratic regime: the political parties and their leaders.

\section{The role of the political parties and affiliation to the leader.}

It would be of use at this point to remind the reader of the role the political parties play in functioning democracies. They provide an organizational base for elites to compete and to mobilize the masses. They are both "integrative and competitive" (Eldersveld and Walton, 2000:14). The political parties recruit leaders, formulate policy, and mobilize support (Eldersveld and Walton). They provide a linkage between the citizens and the government. They allow for some sort of accountability towards the public, and a way to let the masses' needs be known. The local structures of parties "maintain close relations to the public, select candidates, raise money, recruit personnel, determine issue position." (Eldersveld \&Walton, 2000:144) They also have an educational function informing citizens about the issues, the candidates and the votes. The parties allow for a "meaningful citizen participation, governmental stability, maintenance of public order, effective representation of social groups, responsiveness of elites to mass needs and problems, and increasing acceptance of the political values of 
democracy" (Eldersveld \&Walton, 2000: 411). The leaders in these parties or the elites have "significant national influence" (Putnam, 1976: 46). They arrive to influential positions through permeable channels from other professions and fields such as the business field, from the institutions in place such as the parties or the military or the local universities. (Putnam, 1976). It remains to be said however that the concept of democracy, or ruling of the people by the people, is incompatible with the presence of elites. That is what Pennock termed as "democratic tension" (as cited in Aberbach et al.1981 : 207), the tension between liberty and equality that will always exist in functioning democracies. Or, as Robert Michels argues, that "every system of leadership is incompatible with the most essential postulates of democracy." (as quoted in Aberbach et al. 1981: 170). This proves to be true in a traditional society such as the one in Lebanon. Not only is it a traditional society but it is also a plural society made up of many segments divided along the lines of eighteen different religious sects. A further characteristic of a plural society is that "political parties, interest groups, media of communication, schools, and voluntary associations tend to be organized along the lines of segmental cleavages" (Lijphart, 1977: 3). That describes very closely the Lebanese social and political scenes.

On the political scene, the "grand coalition" is essentially between the leaders or the "elites" (to use Eldesveld's and Walton's term, 2000) or the "influentials" and the “decision makers” (Putnam, 1976) of each segment. These segments are represented through numerous political parties, usually formed along religious lines, and they do have 
a predominantly Christian or predominantly Muslim constituency. Along those same lines, the leaders of these parties are at the same time the traditional leaders of the segments. They are elected to the parliament and are part of the government and therefore of the grand coalition. The leaders participate in the political process through elections and other democratic institutions. It is then an intriguing mix of western qualifications and local factors that play in the make-up of the political parties in Lebanon. On the one hand, the presence of numerous political parties is an important sign of a democratic regime that allows for conflict and differences. On the other hand, the political parties in Lebanon are formed along religious affiliations. They are led mostly by prominent political families, and the leader's post is handed down from father to son. That seems to be at odds with what is seen in the western literature where parties are considered as "continuous bodies not dependent on the founding leader (or leaders), are local and at the same time national units, are self-conscious determinant of leaders to make decisions, and are seeking followers at the polls" (La Palombara, 1966 :6).

In Lebanon are the political parties seen as channels of political participation and representation ? Are they seen as an organizational base for the elites to compete, to mobilize the masses, formulate policy and recruit leaders? Also do the Lebanese see the parties as allowing some sort of accountability of the leaders towards the public, and a way to let the masses' needs be known (Eldersveld \&Walton, 2000)? Are they alleviating the pressure coming from "mass participation" (Huntington, 1968) or acting as a "transmission belts for pressure from lower down"( Daalder, in LaPalombara. ed. 
1966: 71)?

In 1995 the Lebanese Institution for the Permanent Civil Peace had a survey done by Abdo Ka'i, and focused on the Political parties in Lebanon. The results were published in a book edited by Antoine Messarra and later mentioned in Farid ElKhazen's study on the Lebanese Political Parties. The survey studied the commitment of the Lebanese adult citizens to the political parties and associations (el-Khazen, 2002 :61). The results were as follows:

\begin{tabular}{|l|l|}
\hline $10 \%$ & $\begin{array}{l}\text { of those living in the larger cities said they were committed to a political } \\
\text { party }\end{array}$ \\
\hline $62 \%$ & of the respondents refused to be connected with political parties \\
\hline $69 \%$ & $\begin{array}{l}\text { of the respondents saw that political parties complicate matters } \\
\text { expressed their doubt as to the capacity of the political parties to enhance } \\
\text { democracy and unity in modern societies }\end{array}$ \\
\hline
\end{tabular}

Table 4. Commitment of Lebanese to political parties.

Source: Lebanese Institution for the Permanent Civil Peace as quoted in el-Khazen, 2002

It is important to note that this survey is dated 1995, just as the country was coming out of the ravages of the war between the armed militias, including the militias of the different political parties. The citizens had not yet recovered from the atrocities of the war and as a result ended up being under the occupation of the Syrian regime. All of those factors lead to an unfavorable view of the political parties. That attitude is similar 
to the one found in the IRI, LOAC and Statistics Lebanon survey conducted between May 14 and June 11, 2007, which found that political parties "tend to receive blame for Lebanon's troubles." The same survey also found that most respondents do not belong, and would not consider belonging, to any political party. One exception is an extraordinary high level of potential participation among young people in Lebanon. Of those who would consider joining a political party $72 \%$ are between the ages of 18 and 39. That is more than twice the number than would consider joining a party in any other age category."

This ambivalence of feelings that the Lebanese show towards political parties is shown in the results of an earlier LOAC, IRI, and Statistics Lebanon poll, that took place between June 14 and July 10, 2006. It showed, among other results, that $62 \%$ of the respondents "prefer voting for candidates representing political parties or groups." Also, and "While the vast majority of Lebanese are not members of a political party, $78 \%$ of the respondents expressed a preference when asked which political party best represented their point of view." Asked which political party best represented them, "the answer "no one" received the highest percentage of $21.92 \% . "$ The overwhelming majority of Lebanese support peaceful methods for political transition and reject the use of violence. A clear majority (86\%) - from all regions and sects - opt for non-violent, democratic and legal means of achieving their political ends." (Figure 12) 


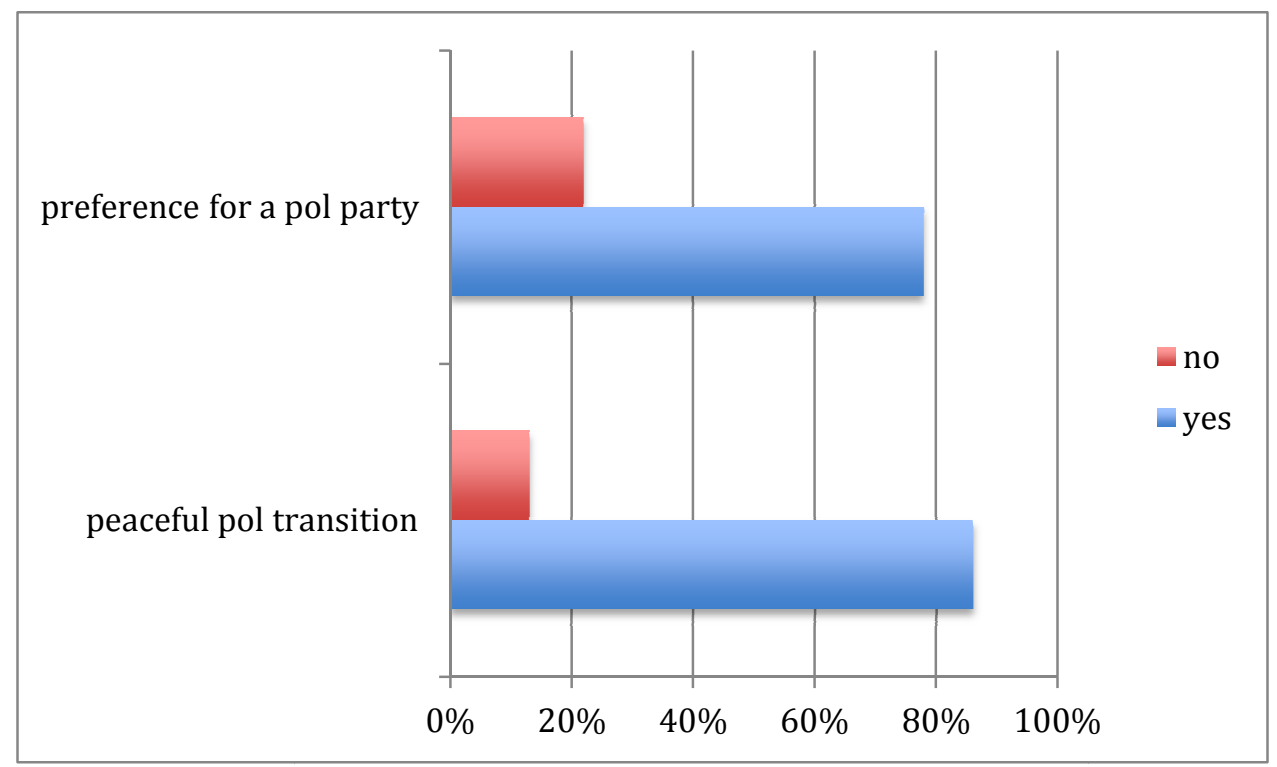

Figure 12: Preference for a political party and for a peaceful political transition Source: LOAC, IRI, and Statistics Lebanon, July 2006.

Most of the respondents do not plan on joining a political party in the future and are cynic about the parties' role. On the other hand, "the majority of those polled believe that non-governmental organizations can have a positive impact on public policy in Lebanon. “

In 2004, the Beirut center for Research and Information published a report about the Political parties and Confessionalism. The report found that the political parties in Lebanon could play a major role in steering the country away from political confessionalism and from the system built on religious affiliations. However, the fact that the political parties in Lebanon have a "religious identity" causes a major obstacle in the move towards political secularism. This fact will be discussed in further details in a 
later section about the Challenges to the Consolidation of Democracy in Lebanon. The overwhelmingly religious identity of the political parties leads to a membership that is limited to a single religious affiliation, stamps the political party with the religious connection of its leader, and makes it difficult for that leader to play a national role independently and away from the one in his religious group. The leader, and with him the political party, will always be considered as part of and representative of his (and it is mostly a male leader) religious rite rather than a political view or agenda. One glaring example is Hezbollah, which is made up of a crushing Shiite majority. Very few Sunnis, Druzes or Christians carry a Hezbollah membership. In the party's role of formulating policy, there will always be a doubt that the programs or agenda suggested by the party are meant to benefit the whole country rather than the narrow goals of the concerned religious rite. The masses' needs are transformed into the religious rite's needs. The political competition that should be based on platforms and reform programs, are transformed into contentions among the religious rites. Formulating policy and ensuring the elite-mass linkage are always viewed through the lenses of the religious rite rather than the whole country.

The political parties are also built mostly around the personality of the leader rather than around a political philosophy. The leader is consequently followed blindly without questioning. The political party is therefore treated as personal property handed down from father to son (Beirut Center for Research and Information, Issam ISMAEL, Oct 2004). That too does not fit into the mold of the western political parties where, in 
functioning democracies, the parties choose and promote leaders who are accountable to the people and who follow a political and secular agenda. In Lebanon, quite often, the leader comes from a prominent family well known for its political past, and expected to keep providing the future leaders. The leaders are not accountable to the people since they are not elected, but on the contrary, are followed blindly.

In October 2006 Information International conducted an opinion poll to study the Lebanese attitude towards their political leaders. Eight hundred citizens were polled with an even distribution among confessions and from the various mohafazats. The results of the poll showed the willingness of the Lebanese to " show remarkable and strong loyalty to their leaders. They also have shown a great resistance to any change in their loyalty, signifying the rigidity of Lebanon's political and social symbols." Another interesting finding of this poll is that the Lebanese tend to "perceive issues through the eyes of their leaders more than their confessions."

A poll published in An-Nahar the 27th of July, 2007 showed that the Lebanese people's primary allegiance is to the "za'im" or leader, rather than to the political programs. A study conducted by Information International, surveying a sample representing all regions and sections of Lebanese society, showed that $65.5 \%$ of the respondents say they have allegiance to the leader. There is a tendency to worship the leader, as if they were "half-deity." They are followed blindly, even when they switch positions. They also fill the role of providing services to their followers in the absence of a government. The void left by the incompetence of government agencies and the lack of 
basic services normally provided by a functioning government is filled by the "za'im". That leads to the immunity of the "za'im" against accountability by making him indispensable. This fact is true among all religious affiliations.

Another Information International poll done between June 2 and June 9, 2008, addressed the Lebanese citizens' attitude towards politicians in general and towards the leaders of each religious group. The poll covered 1000 Lebanese from across the country. The notable results were that $78.4 \%$ of the respondents do not trust politicians. Addressing the citizens' allegiance to the "za'im" in each confession, $97.4 \%$ of the Shiites are loyal to Hassan Nassrallah (the Hezbollah leader) and 96.7\% of the Shiites see that Nabih Berri, the leader of Amal, the other Shiite party allied with Hezbollah, has an excellent or good performance. The loyalties among the Christians to their leaders are not as high and they have more than one leader. The Christians in the country have more independence in their thinking and they seldom follow a single leader. In comparison, Sunni respondents show a high degree of loyalty $(75 \%)$ to their one uncontested leader Sa' ad al-Hariri. The Sunnis or the Shiites have one uncontested leader, and it is quite threatening to the few independent Shiites to speak up against the declared leader. The same rings true for the Sunnis whose declared leader is the son of the assassinated Prime Minister Hariri.

This allegiance to the leader is a trait of a traditional society where loyalties to the family or the clan leader is prevalent. This aspect will be discussed further in the Challenges to the Consolidation of Democracy section. Following the leader also 
includes following that leader's attitude towards neighboring countries: the same 2008 Information International poll surveyed 1000 Lebanese from across the country about "their position towards Arab and foreign countries, relations with Syria and other issues." The results showed that the Lebanese positions towards Arab and foreign countries reflect greatly the attitude of their za'im towards that country. For the purpose of this survey, the term "leader" does not include the clerics: one question asked whether clerics should meddle with politics: $57 \%$ of the respondents said that they should not.

As for the political parties, the 1995 survey mentioned earlier, and done by the Lebanese Institution for the Permanent Civil Peace, showed anger and resentment towards the political parties. The major reason behind that is the role they played during the war, their transformation into an armed militia and resorting to violence rather than the democratically agreed upon process to resolve conflicts: $62 \%$ of the respondents refused to be connected with political parties. As for the capacity of the political parties to offer effective solutions to the problems facing society, $69 \%$ of the respondents saw that political parties complicate matters rather than help with solutions, and $51 \%$ expressed their doubt as to the capacity of the political parties to enhance the democracy and unity in modern societies.

The 2004 poll done by the Beirut Center for Research and Information about the role of political parties found that the negative and almost hostile view the citizens held in 1995 towards the political parties had changed. By 2004, they are seen as a possible player in steering the country away from political confessionnalism and towards a 
secular government. However, the overwhelmingly religious identity of the parties' membership and the fact that they are built around the personality of the leader makes it difficult for them to realize such a role.

The above mentioned surveys do show the political parties as mobilizing the masses, letting their needs be known, providing an educational function informing citizens about the issues, the candidates and the votes, "allowing for citizen participation, and increasing acceptance of the political values of democracy" (Eldersveld \& Walton, 2000: 411). The fact that the political parties moved away from the peaceful conflict resolution they are designed to achieve in a democracy, and transformed into armed militias during the war, that in itself turned the citizens against them for a while. This aversion to the political parties as a result of their resorting to violence is in itself a manifestation of a "culture of democracy" (Hanna, 2008).

Before ending this section about the political parties, it is important to note that over eighty political parties exist in the country, and this large number speaks volumes to the freedom of expression and of assembly in Lebanon. Also the fact that the citizens have the choice of joining any political party from among the numerous ones operating in the country demonstrates the presence of a culture of democracy. As for the fact that the political parties allow for accountability and transparency in the political system, and the necessary move away from religion and confessionalism, these were addressed in the following surveys. 


\section{Accountability and transparency of government.}

A September 2003 survey done by Information International addressed the need for administrative reform and how to go about it. A random sample of 600 Greater Beirut residents was surveyed between September 25 and 29 of 2003 . To the question of how real administrative reform would be realized, the answers came as follows:

\begin{tabular}{|l|l|}
\hline $20.6 \%$ & called for the application of the Illicit Wealth Law \\
\hline $20.2 \%$ & wanted the elimination of the confessional system of politics \\
\hline $17.9 \%$ & called for the adoption of a merit-based system \\
\hline $16.7 \%$ & proposed the dismissal of corrupt employees \\
\hline $12 \%$ & suggested restructuring the public sector \\
\hline $11.4 \%$ & called for an end to politicians' interference in the administration \\
\end{tabular}

Table 5. How real administrative reform would be realized.

Source: Information International, 2003

What is mostly relevant to our study is the necessity to adopt a merit system in the public sector, which implies getting rid of the confessional system in politics, an issue at the root of the challenges to the consolidation of democracy in the country. There were many calls recently (in 2009 and 2010) to put an end to the political confessionalism, set into motion in 1992 when the Taef Accord was applied. It divided the parliament seats 
equally among the Christians and the Muslims, with the Christian half divided proportionally among the different Christian rites, and the Muslim half also divided up proportionally among the different Muslim confessions. However, and even though it was called for in the Taef Accord, putting an end to the political confessionalism was never attempted. Another call by the speaker of the Parliament in 2009 to start the phasing out of the political confessionalism was met with skepticism, cynicism, and accusations of hidden motives as it was reported in the print and broadcast media at that time. The topic of political confessionalism was addressed in many surveys and will be discussed in more details in its own section below.

Another survey that looked at government accountability was mentioned earlier, and it studied the Lebanese thoughts about the war and its results. It was done by Information International in April of 2003, on the occasion of the anniversary of the war that started on April 13, 1975. 87.7\% of those surveyed believed that the war did not accomplish any of its goals (whatever these were considered to be), and $44.5 \%$ were for bringing to justice the leaders of the different militias that participated in the war. The militias were the armed factions of the political parties that were major players on the political scene and represented in the Lebanese Parliament. That explains the negative attitude the Lebanese had towards the political parties after the war ended. The militia leaders were not brought to justice; instead they were made members of the Cabinet of Ministers, with the exception of three of the Maronite leaders. The three were antiSyrians and ended up being either exiled to France or put behind bars. All of that did not 
bring a good closure to the events that had traumatized the country for almost two decades, not to mention the fact that there was no accountability for the violence and the crimes committed during the war.

The same 2003 Information International survey mentioned earlier about government accountability, also showed the majority of the respondents as seeing the government accountable to the people directly or to the parliament, which is elected by the people. These elections happen every four years, nation wide to elect the 126 members of the parliament. These elections are preceded by electoral campaigns, ads, and political rallies organized by the different political parties. Taking into account the fact that Lebanon is surrounded by countries ruled by a single party, and where the winners of the elections win by a $99 \%$ majority after having thrown the opposition representatives in jail, or prohibited them from running, taking all of that into account gives the elections in Lebanon an added importance. Several of the surveys mentioned above addressed the value that the Lebanese attach to voting and to elections. Many more listed and described below show the importance the Lebanese attach to the parliamentary elections.

\section{The nature and value of the elections.}

A post-parliamentary election opinion poll was done between September 23 and October 5, 2000 by Information International. Among the questions posed, the relevant one to this study asked the respondents if they had participated in the last parliamentary 
elections. A large majority of the respondents, 73.4\%, answered affirmatively, even if only $41.1 \%$ of the respondents believed that the elections were honest to a moderate degree, $25.4 \%$ saw it honest to a high degree and $17.8 \%$ honest to a low degree. The high degree of participation is significant when one realizes that $29.3 \%$ of those polled saw that there was foreign intervention in the elections and $68.9 \%$ of these respondents specified that there was a Syrian intervention in the elections. 30.0\% said they did not know if there were any interventions, although these elections took place during the Syrian occupation of the country. $52.4 \%$ of the respondents were satisfied with the electoral process, $31.3 \%$ were not satisfied, and $16.3 \%$ did not know (Figure 13).

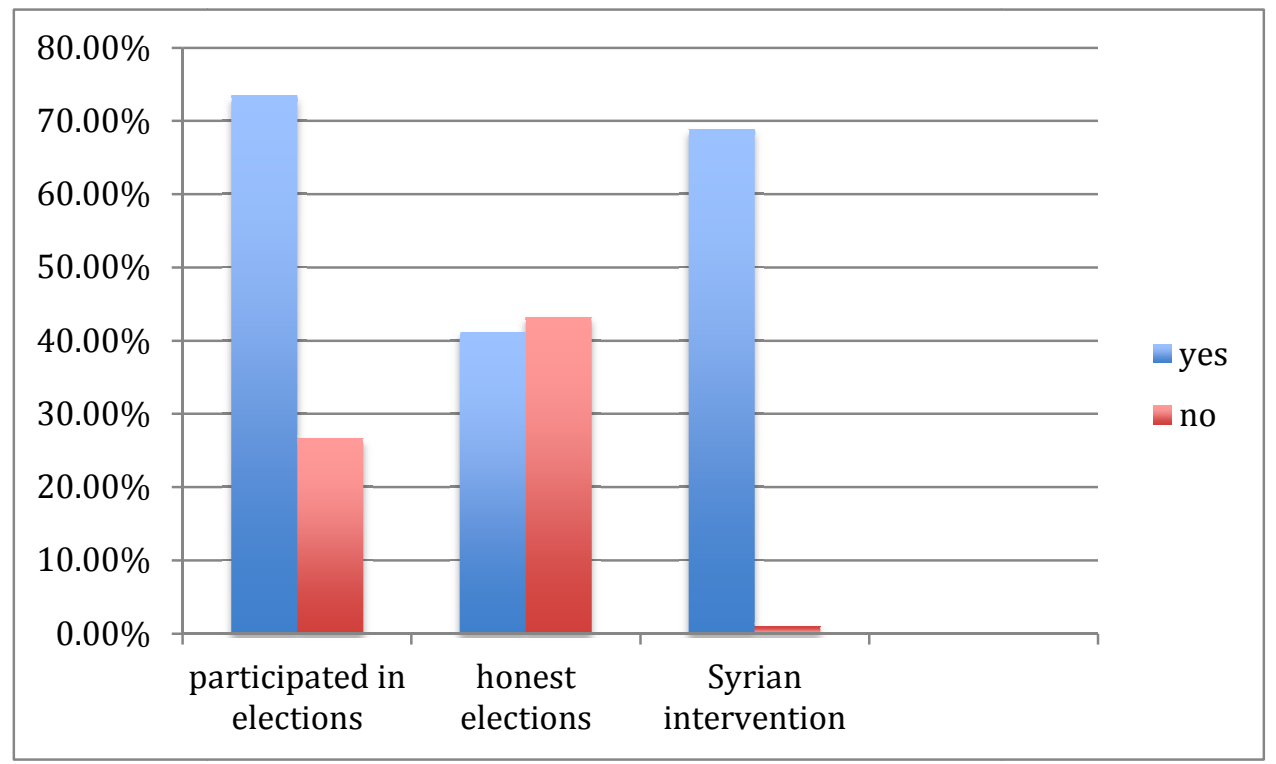

Figure 13: 2000 parliamentary elections

Source: Information International, October 2000.

Another Information International study commissioned by the UNICRI and done 
in 2000 looked at the Constitutional and Legal Faults of the 2000 election law. The study was published in An-Nahar newspaper on two consecutive days, May 12 and 13, 2005. It uncovered the many infractions that took place during the days and months leading up to the parliamentary elections of the year 2000 and during the elections. In addition to publishing the survey, An-Nahar added more details to the events that took place around the 2000 elections describing many instances where the system was manipulated to provide a pro-Syrian majority in the parliament and consequently a proSyrian government. The articles mentioned the fact that tens of thousands of Kurds, Palestinians and Syrians were granted the Lebanese nationality through a decree rather than a law, and their vital records were placed in specific areas of the country to tip the population make-up in favor of the pro-Syrian candidates. The same Information International study (2000) unveiled widespread "gerrymandering" throughout the electoral districts, interferences and pressure by the Syrian forces and security agents. Buying votes and buying candidates out of the process were also reported in the study. Unfair and uncontrolled access to media outlets, and the unregulated use of the media by candidates, especially those who already held official positions, or those who possessed the financial means to buy unlimited access, all of the above mentioned factors gave an unfair advantage to some candidates against others, according to the study.

In 2000, and after the parliamentary elections, many of those surveyed by Information International did participate in the elections, even though only $41 \%$ of the respondents saw these elections as moderately honest. Also a majority of the 
respondents saw that there was Syrian intervention in the elections, as reported by the An-Nahar article related to this election. Even though there were elections, and the principle of parliamentary elections was still respected and kept in place, the system was manipulated in a way that turned it favorable to the powers controlling the land.

The attitude towards the importance and necessity of the elections is also present in another Information International study done in 2004 and published in the iMonthly of August 2004 under the title "Elections Are Necessary Even When Fraudulent: a Study". A stratified sample of 600 residents in the Greater Beirut area, between the $16^{\text {th }}$ and $21^{\text {st }}$ of June 2004, was interviewed face to face. The majority of the respondents, $72.5 \%$, support the principle of elections, while $26.3 \%$ have an unfavorable view, divided up as follows:

\begin{tabular}{|l|l|}
\hline $51.2 \%$ & see that elections allow for the opportunity to freely express opinion \\
\hline $21.3 \%$ & see the elections as an occasion to hold representatives accountable \\
\hline $13.3 \%$ & $\begin{array}{l}\text { see the elections as favoring the rule by the majority rather than by those } \\
\text { who are competent }\end{array}$ \\
\hline $13 \%$ & see it as a futile exercise in a developing country \\
\hline
\end{tabular}

Table 6: Lebanese Attitude Towards Elections.

Source: Information International, 2004. 
This result came even when $70.2 \%$ of the respondents saw that the 2000 parliamentary elections were fraudulent. Even with the knowledge that there are widespread irregularities and fraud in the elections, they were still worth having.

It is worth noting that $46.9 \%$ of the respondents make their own list of candidates, rather than using the full lists as they appear. That shows independence in thought and a good exercise of the voting right rather than blindly following the imposed official lists.

Going back to the section about the political parties above and the fact that their leaders come from well-known traditional political families and from the same religious affiliation as the party members, it is of interest to note the masses' attitude towards the background of a political candidate. The 2004 Information International survey mentioned above also asked the respondents about the kind of candidate they prefer. Religious or military men were the least favored ( $6.6 \%$ for clergy and $6.2 \%$ for military), while the majority (44.7\%) preferred an intellectual personality as opposed to a veteran politician $(31.3 \%)$, or a businessman $(11.2 \%)$ as shown in figure 14 below. The stigma associated with a military man ruling the country results from seeing the results of the coups d'état in the neighboring countries that brought military men to power and to authoritarian and ruthless regimes. As for a religious figure at the helm of the government, it is not seen favorably as revealed in the results of some of the surveys mentioned earlier, and especially if it meant the application of the Shari'a law. 


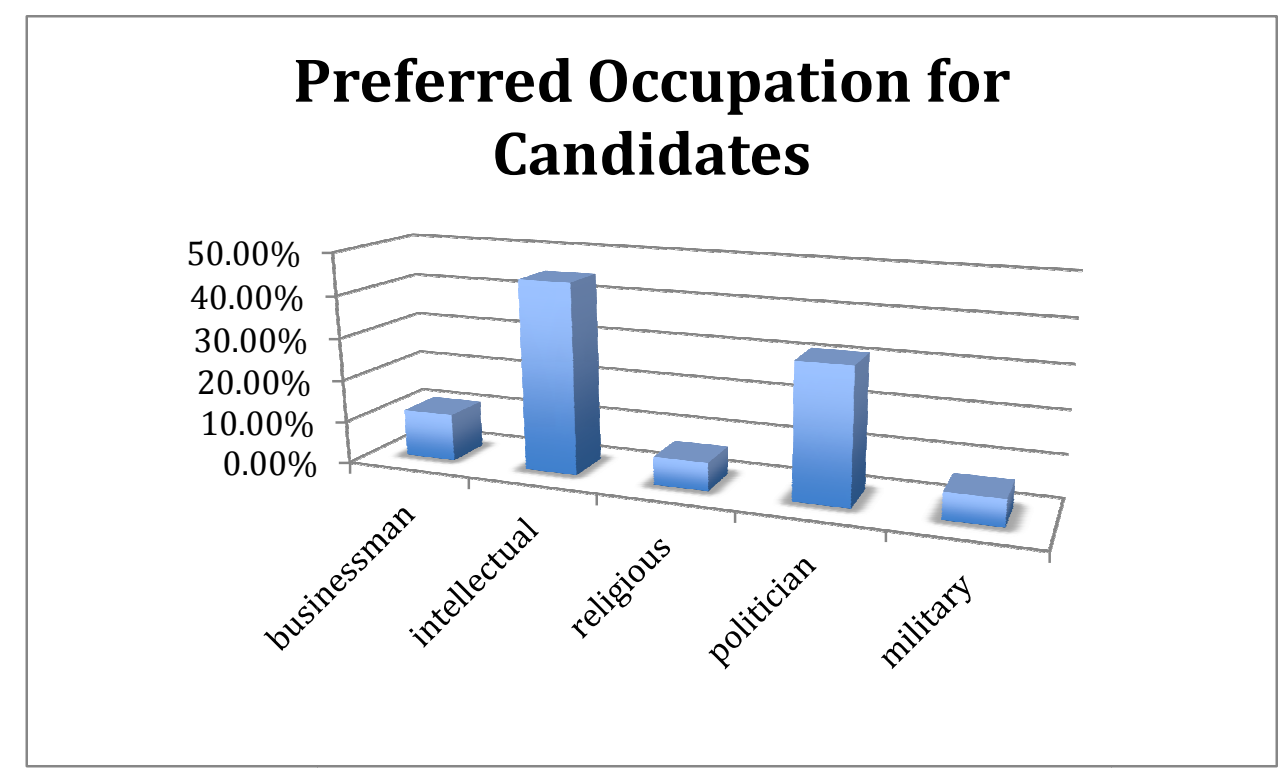

Figure 14: Preferred Occupation for Political Candidates.

Source: Information International, 2004.

A 2005 Information International opinion poll about the Elections and Syrian Withdrawal was published in iMonthly in May of 2005, issue 35, with the following results: $84.7 \%$ of the respondents were for the election in May, $74.1 \%$ with the Syrian Withdrawal. The poll asked a sample of the Lebanese in the Greater Beirut area between the $7^{\text {th }}$ and $11^{\text {th }}$ of April 2005. "The majority of the respondents $(83.6 \%)$ said they would participate in the elections, while $7 \%$ had not decided yet and $9.7 \%$ stated that they would not take part."

The series of polls mentioned earlier, done between June of 2006 and April of 2008 by the Lebanese Opinion Advisory Committee, the International Republican Institute, and Statistics Lebanon had a strong majority (94.4\%) of the respondents saying they believe in the importance of voting, $85.4 \%$ believe that the purpose of voting is to 
select the right people to participate in the government regardless of their political party or religious sect. $89 \%$ of those polled support a "democratic government and reject the idea that extenuating circumstances would justify a non-democratic government." The majority of the respondents would rather make their own decision than follow the religious leader directives, and a majority of the respondents prefers voting for candidates representing political parties or groups. The importance the Lebanese attach to voting in particular and to political participation and civil society in general is addressed in the following section.

\section{Civil society and political participation.}

The Fourth National Convention on Democracy and Youths Participation in Public Life took place in Antelias on the 12,13 and 14 of December 2003. Present at the convention were many professors from different universities and different confessions. There were also students from countries other than Lebanon who participated in the convention; they came from Jordan and Syria, but mostly from Lebanon and all of its different mohafazats (counties). Different faiths and both genders were equally represented. The young participants insisted on having or creating the "human-citizen society called civil society" (p. 8 of the published study). The convention concluded by highlighting the importance of the youths' participation in public life in its "threepronged foundation: democracy, participation and public life" (p. 16).

On that same note, a survey mentioned earlier in this section, and published in the 
youths' annex of the An-Nahar newspaper, Nahar el-Shabab, on August 9, 2006, looked at the definition of democracy as seen by the youths, and at their sources of information. The study was done in cooperation with the YMCA, the International Association for Administration and Training, and the Colloquium for Parliamentary Dialogue. The survey results prove to be of use to prove the point of the youths' participation in the political life and in civil society: in addition to showing that $90 \%$ of the participants knew the definition of democracy as the rule of the people by the people, the survey asked if they had practiced democracy in one way or another. $98.4 \%$ of those over 47 years of age answered affirmatively, with $92.4 \%$ of postgraduates. Half of the young people who were polled saw that joining a political party is a road to leadership. $94.8 \%$ of the all surveyed respect others' opinion with only $1.8 \%$ believe in using force to impose their opinions as illustrated in figure 15 below.

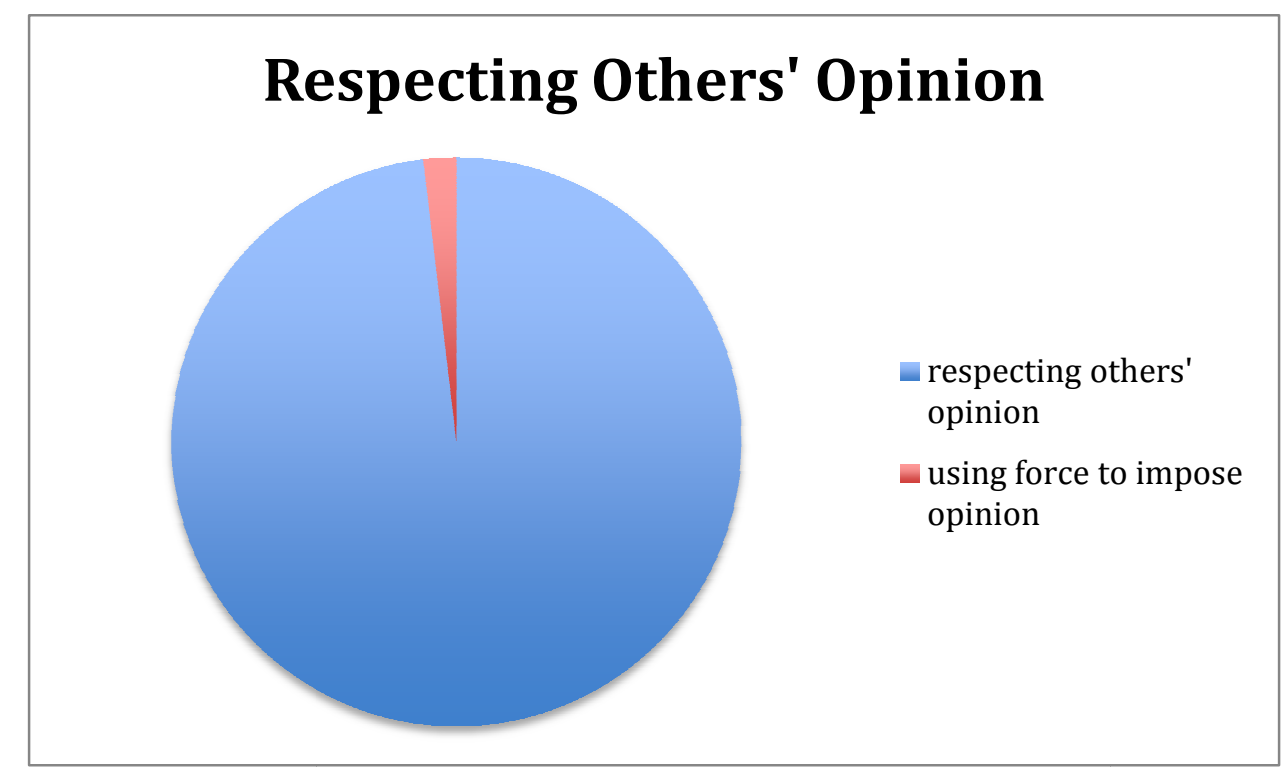

Figure 15: Can A Political Opinion Be Imposed By Force? Source: An-Nahar, August 9, 2006 
Getting the younger generation to be involved and be influential in the political life of the country is a clear indicator not only of an active democracy but also of an engaged citizenry and a belief that democracy is or should be "the only game in town". Being informed, participating in activities pertinent to democracy, joining a political party, and respecting others' opinions are all factors of an active civil society and a participatory democracy. It is also worth noting that one of the answers to the survey done in 2000 by Information International after 200 days and then again after 300 days of the new government, showed the respondents considering the government answering in part to the people, or to the parliament but also $8.8 \%$ of them after 200 days and $7.2 \%$ after 300 days saw the government answering to NGOs. Thousands of NGOs operate in Lebanon, ranging from the local church charitable association, to professional syndicates to international organizations. The multitude of these NGOs mentioned earlier in this thesis are part of the civil society that makes up one of the interdependent, complementary and inseparable arenas of democracy.

\section{The constitution and constitutional amendments.}

The Lebanese Constitution was promulgated in 1926, and along with the unwritten National Pact, made up the guidelines to govern the country as a "parliamentary democratic republic based on the respect for public liberties." When the country came under the Syrian occupation, the elections and other political actions continued to take place, under the umbrella of the Constitution. The reactions of the 
Lebanese to the elections and other events that took place under the Syrian occupation, were polled in the following surveys:

A December 2004 Information International opinion poll published in issue 30 of iMonthly addressed the extension of President Lahoud's term, the new government and Resolution 1559. The election of the Lebanese President is governed by the dictates of the Constitution. Renewing his mandate for a three-year period during the Syrian occupation through an amendment of the related article of the Constitution was a cause for disagreement among the Lebanese and was not supported by a large number of them. The Information International poll looked at the Lebanese attitude towards this extension of the President's mandate. $51.8 \%$ of the respondents did not see a problem with the term extension, while $35.8 \%$ opposed it, and $12.4 \%$ replied "I don't know", as illustrated in figure 16).

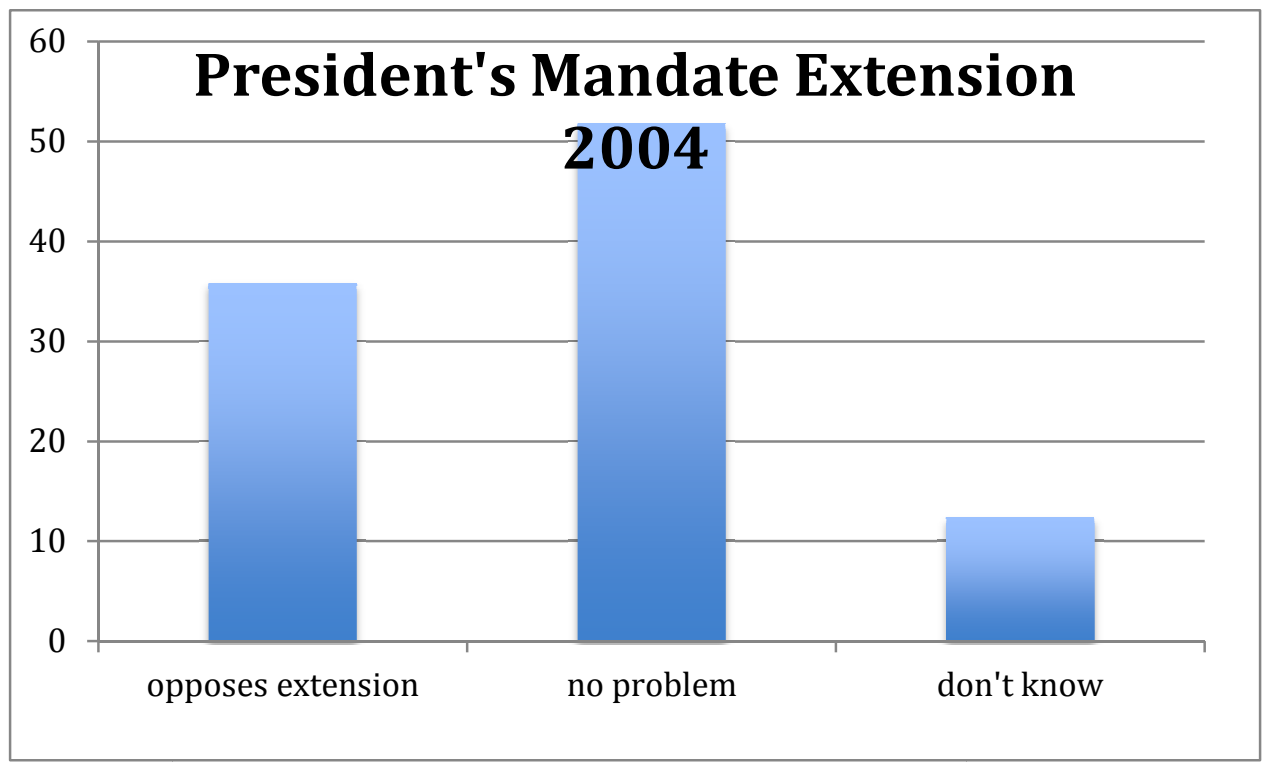

Figure 16: Opposition to the 2004 President's Mandate Extension. Source: Information International 2004 
Broken down into the different religious rites the responses show the majority of the Druze, $66.7 \%$, and of the Maronite respondents, $52.9 \%$, opposing the extension and the manipulation of the Constitution that allowed for it to happen. On the other hand, a majority of the Shiites respondents, $61.3 \%$, and of Roman Catholics (60.7\%) were for the term extension as shown in figure 17 below:

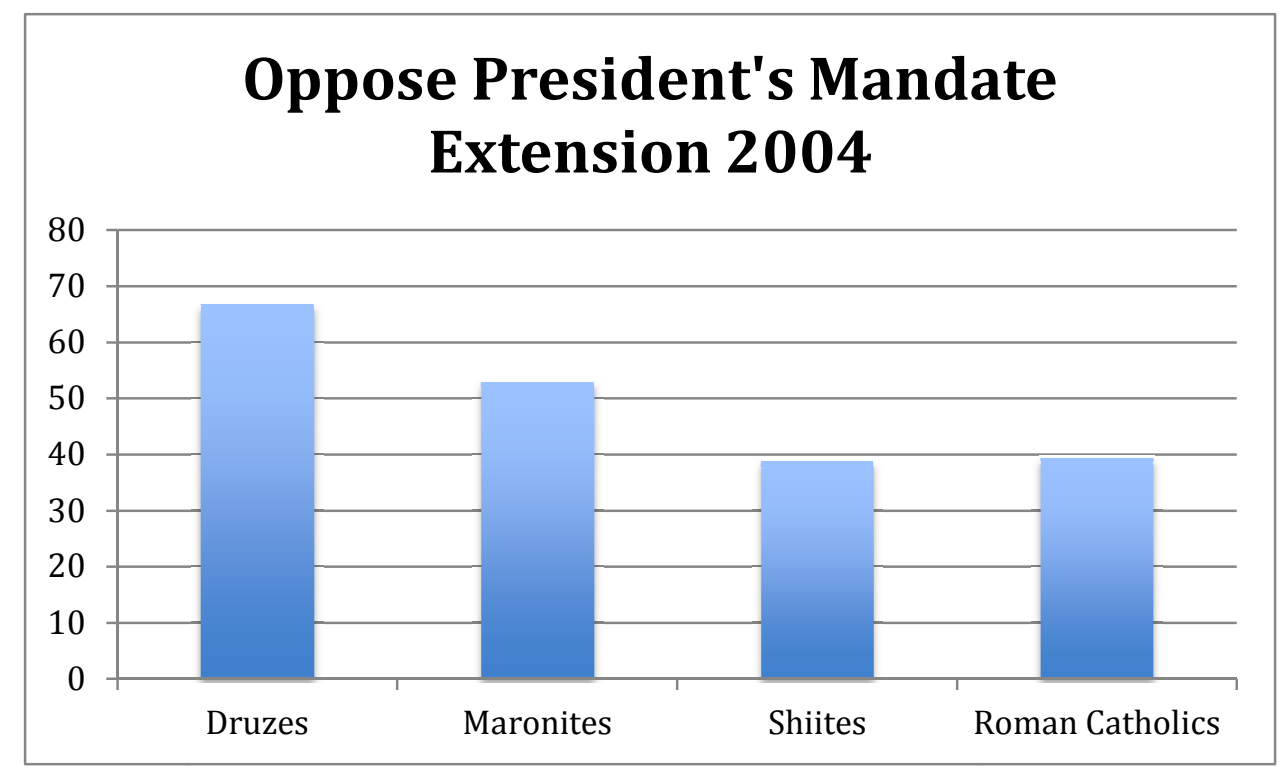

Figure 17: Opposition to the 2004 president's mandate extension, by religious rites. Source: Information International, 2004.

Amending the Constitution to extend the President's term in 2004 did not sit well with the majority of the Lebanese. Not only did it bring an amendment that is not seen as legal to the Constitution but it also extended the term of a sitting president who was pro-Syrian, using the same intimidation tactics that are adopted in the authoritarian 
regime itself.

Statistics Lebanon in March 18-22 of 2006 also polled the Lebanese about extending the president's term. One of the questions of this survey asked the respondents whether they were in favor of or against the extension of the term of the current president at the time, the extension being unconstitutional. $80.7 \%$ of the respondents were against the extension. The percentage was high both among the Christian respondents $(89.10 \%)$ and the Muslim respondents $(75.41 \%)$ alike (Figure 18). That constitutes another sign of the Lebanese citizens' attitude towards democracy: there is no other acceptable system except democracy and what is dictated by the country's constitution.

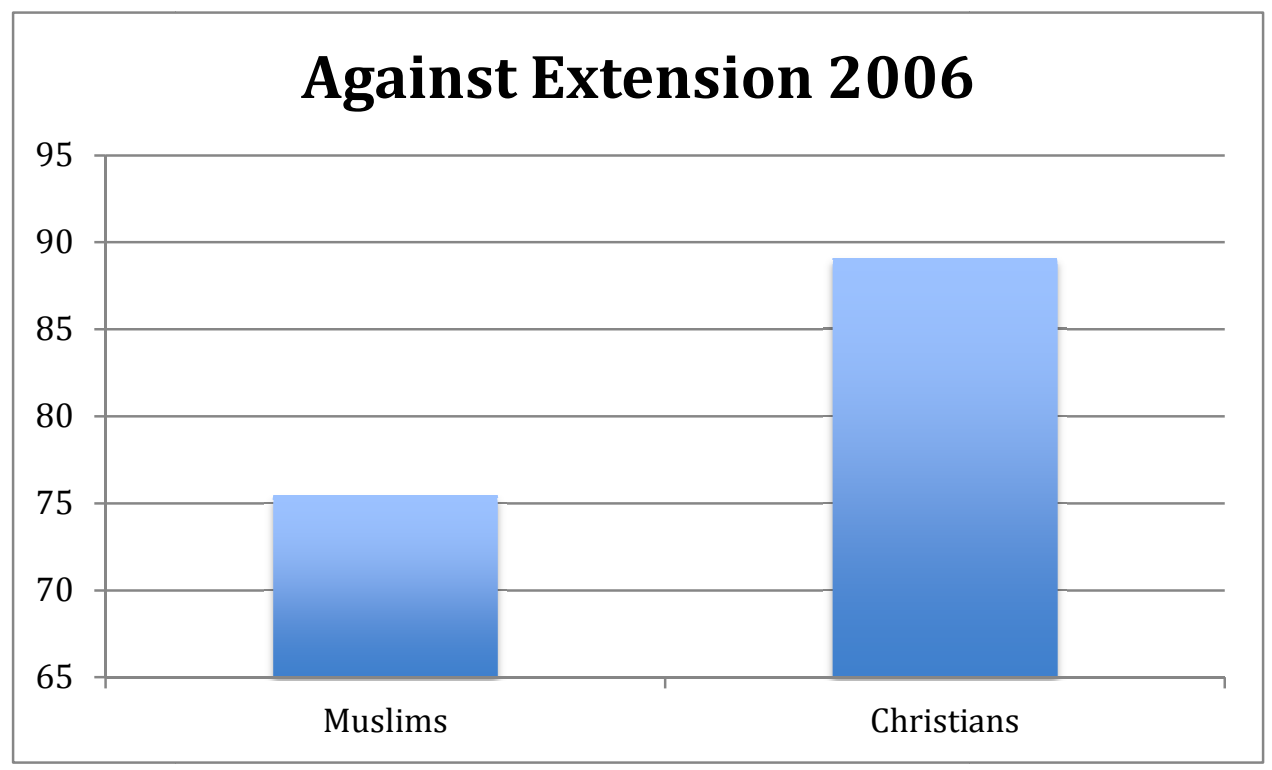

Figure 18: Opposition to the President's Mandate Extension by Religion Source: Statistics Lebanon March, 2006 
The series of polls done between June of 2006 and April of 2008 by the LOAC, the IRI, and Statistics Lebanon studied the attitude of the Lebanese towards national identity, voting and the democratic institutions. In their March 28 - April 8 of 2008 survey, they addressed the question of the Constitution and whether it should be untouchable and without any amendments: $51 \%$ of the respondents saw that it inot permissible to circumvent the constitution under any circumstances." The other half saw that it can be done in some circumstances to preserve national unity. Broken down into different confessions, $41 \%$ of the Christians see it permissible to circumvent the constitution in some circumstances, $43 \%$ of the Sunnis agree with this point, compared to a high $72 \%$ of the Shiites. The Druzes have the lowest percentage: $34 \%$ see it possible to circumvent the constitution in some circumstances.

The results of the surveys in Lebanon, as the ones listed in this thesis suggest, are often broken down into the responses of the different religious factions or confessions. These results often differ markedly according to the religious rite of the respondents. The religious factor is entrenched in the political life of the country and is a major player in the political actions and decisions. The trend is to move away from the confessionalism towards a certain laïcité where competence replaces the religious affiliation, and where belonging to a certain religious rite is no longer relevant. The following surveys polled the Lebanese about their opinion of the political confessionalism. 


\section{Political confessionalism in a consociational democracy.}

The division of the government posts and the administration among the different religious factions came to be known as political confessionalism. Many of the Lebanese see this as being at the root of the problems faced by democracy in the country as shown by the following surveys:

Le printemps des interrogations (Springhints - Mind the Gap) published in the Spring of 2007, studied the attitude of the Lebanese towards different aspects of democracy. The Springhints - Mind the Gap surveyed university students and Internet users. The ages were mostly between 18 and 30 years old. Even though the sample did not include all age levels, it did include a cross section of the population that comprised all major political parties affiliation, different socio-economic levels, and all regions. The survey posed a total of 31 questions. Only the questions that serve the purpose of this thesis will be cited.

The first question asked, "In your opinion, does the Lebanese Constitution complicate by its nature the political life?" $77.8 \%$ of the university students and $77.0 \%$ of the Internet respondents answered affirmatively. They considered the confessional system instilled by the Constitution an obstacle in the way of an egalitarian democratic regime, distributing government and parliamentary seats according to a complicated power sharing formula among different religions and confessions.

Question 2 asked if the required consensus between political-religious factions on key issues got in the way of an objective and constructive treatment of social 
problems (education, justice, security, health care, economy, etc.). The answer was a $61 \%$ yes among university students and $62.6 \%$ among Internet respondents.

Question 3 asked if the representation according to the religious and confessional affiliation leads to allegiance to relatives, persons and families, rather than to ideas and political programs. $54 \%$ of the university students and $63.6 \%$ of the Internet respondents answered affirmatively.

Question 5 asked if the project of political "deconfessionalisation" or moving away from confessionalism towards "laïcité" as stipulated in the Taef accord, contradicts the principles of consociational democracy, or as it is described in the survey, of "consensual democracy"? $41.4 \%$ of university students and $43.3 \%$ of the Internet respondents said yes, while $58.6 \%$ of the university students and $56.3 \%$ of the Internet respondents answered negatively. A slight majority then sees that there is no contradiction between the call of the Taef agreement for an end to political confessionalism and the nature of the consociational democracy.

The laïcité in Lebanon is seen very differently from the one in France, where there is a complete separation between the state and the Church as a result of the French Revolution. In Lebanon the religion is closely related to how the individual citizen sees himself/herself. The religion is an integral part of one's heritage, and "our respect of the religious takes on the dimension of loyalty to one's past, a loyalty that is as natural as it is gratifying" (Springhints, $2007: 41$ ).

Question 16, along those same lines, asked about what would threaten the long 
term presence of the different religious communities in Lebanon. The majority or 57\% of the university students and $57.8 \%$ of the Internet users identified the confessional system, $25.7 \%$ of the university students and $25.3 \%$ of the Internet users saw it threatened by the laïcité, and $17.3 \%$ of the university students and $17 \%$ of the Internet users saw the threat in the deconfessionalization.

Question 7, made up of 4 sub-questions, addressed the legislative modifications needed to lessen the allegiance to the confession, in order to favor that to the country. Sub-question 7-4 asked specifically about laïcité. It defined laïcité as the total separation between civil and religious instances, and asked whether applying this total separation would replace the allegiance to the religious confession with the allegiance to the country: $60.4 \%$ of university students and $72 . \%$ of Internet respondents answered, "yes, immediately," with $17.7 \%$ of university students saying maybe some day and $21.9 \%$ answering negatively, versus $13.0 \%$ of Internet respondents saying maybe some day and $14.10 \%$ saying no, as illustrated in figure 19 : 


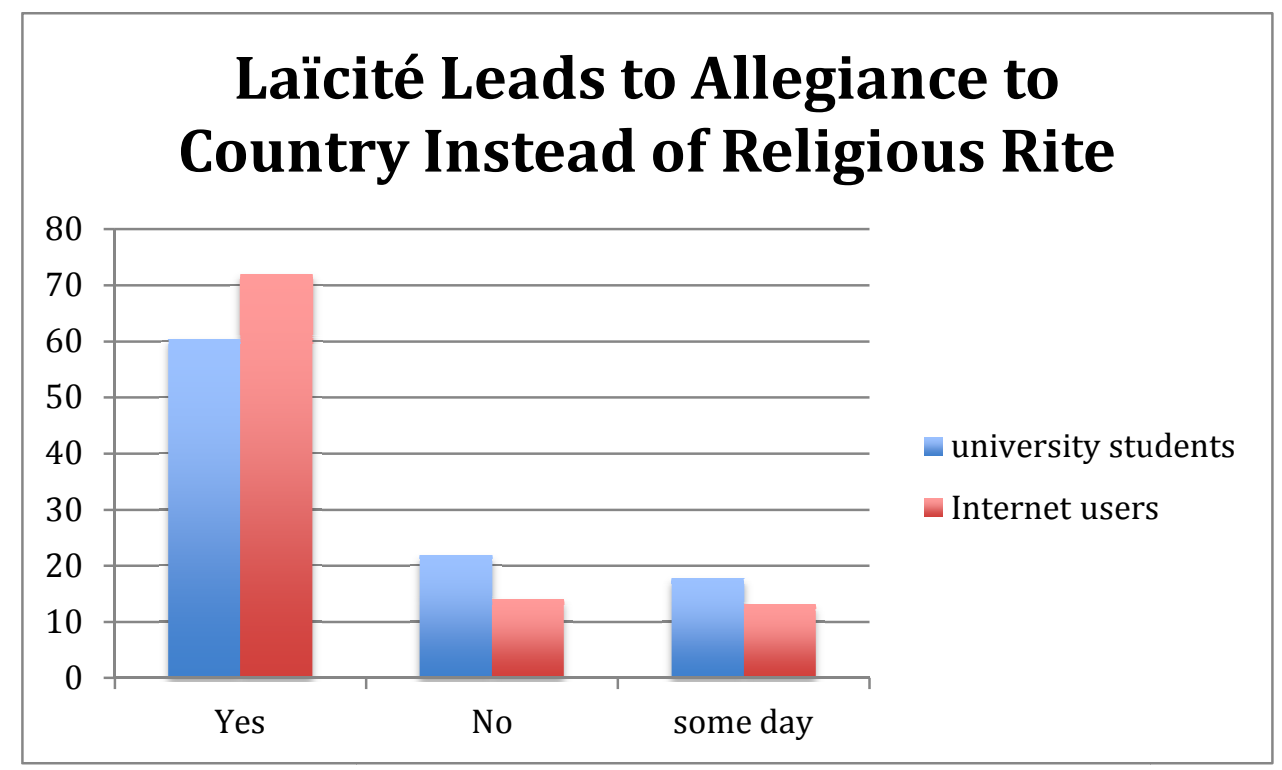

Figure 19: Laïcité and Allegiance to Country instead of Religious Rite.

Source: Springhints 2007

With the Lebanese society being composed of Muslims and Christians and a parliament divided equally between the two, Question 9 addressed the possibility of the Islamization of the country's laws. It asked if it was possible that one day the Koranic law would "impregnate the Lebanese Constitution." A majority of $71.9 \%$ of university students and $70.5 \%$ of Internet respondents answered negatively. This question echoes the one posed by the 2005 Zoghby International survey mentioned earlier, and with similar results.

Question 12 asked if in a country where freedom of expression is protected by the Constitution, the religious figures should be spared from criticism, comic jabs and satire. $62.9 \%$ of the university students and $64.7 \%$ of the Internet users said yes. It should be noted that in September of 2005, and after the Jyllands-Posten Danish 
newspaper published comic strips about the prophet Mohammet, riots and attacks broke out against the Danish embassy and other buildings in a Christian neighborhood in Beirut. Other violent reactions took place in June, 2006, after a Lebanese TV comedy show presented, on June $1^{\text {st }}$, a skit including the Hezbollah leader in a dialogue with one of the regular comic actors. This incident falls under the behavioral component of this thesis. However, mentioning it in this section is required to shed more light on the situation in Lebanon and the complex factors involved. They also illustrate how deeply entrenched the religious tendencies are that permeate both the social and the political lives of the country.

Question 25 asked the respondents about their overall impression of laïcité: $24.2 \%$ of university students saw it as the marginalization, almost the oppression, of religions, $50.3 \%$ saw it as an inescapable dimension of any real democratic practice, $38.8 \%$ as a protection of religious practices in all their diversity, and $15.3 \%$ as an easing of moral values. $14.1 \%$ of Internet users saw it as a marginalization of religion, $51.7 \%$ as a dimension of democratic practices, $43.7 \%$ as a protection of religious practices and $11.9 \%$ as an easing of moral values.

To summarize the findings of this major study done in the Spring of 2007 about the attitude towards democracy among university students and Internet users, Le printemps des interrogations (or Springhints-Mind the Gap), we can say the survey showed that the younger generation believes that the Constitution in what it dictates as confessionalism in political life, complicates the nature of political life. The end of 
political confessionalism, as it is called for in the Taef accord, does not contradict the concept of Consociational democracy. The current political confessionalism is actually seen as a major threat to the long-term presence of the different religious communities in Lebanon. The consensus required in major issues was found to be an obstacle in the way of an objective and constructive treatment of social problems. The survey was valuable in its depicting an authentic picture of the Lebanese culture and the way the Lebanese see their system and the strong presence of religion in their daily life. Even though the respondents wanted to do away with confessionalism, they still did not foresee the disappearance of religion from their day-to-day life. It is an integral part of who they are and of their heritage. Another question on the survey asked if religious figures and leaders should be spared from jokes and jabs in comedy shows and an overwhelming majority answered affirmatively.

The September 2003 Information International survey about administrative reform also addressed the confessionalism in politics, highlighting the necessity of adopting a merit system in the public sector. Doing so implies getting rid of the confessional system, an issue at the root of the challenges to the consolidation of democracy.

The series of polls done between June of 2006 and April of 2008 by the LOAC, the IRI, and Statistics Lebanon mentioned earlier, and the surveys done in May 14 - June 11 of 2007, found another trait that is particular to the system in Lebanon: a majority of the respondents $(63 \%)$ believe that religious leaders should refrain from active 
involvement in politics through making public political statements, while on the other hand $72 \%$ of the respondents believe that political leaders should consult with religious leaders. On that same topic, the same series continued in March 28 - April 8 of 2008 and showed that $60 \%$ of the respondents see that "political confessionalism is historically and deeply rooted in the Lebanese culture and it cannot be removed, even if the will existed to do so." This dilemma is at the heart of the challenges facing the democracy in Lebanon, and the separation of state and religion common in western democracies seems quite problematic in a society such as the traditional one in Lebanon. That point will be addressed in further details in the section reserved for the challenges to the democracy in Lebanon. Another challenge to the democratic regime in the country is the presence of an armed militia that exists side by side with the official army. The armed forces of Hezbollah draw different reactions from the different sections of the population along religious lines. The surveys in the section below address the presence of arms other than in the hands of the army.

\section{The presence of militias in the country.}

The results of most of these surveys are deeply influenced by the religion of the respondents. Keeping in mind the fact that Hezbollah is made up of mostly, if not solely, Shiite members, the results from Shiite respondents are significantly and consistently in favor of Hezbollah, while the opposite is true from the other religions.

In a December 2004 Opinion Poll, Information International surveyed the 
Lebanese about what they thought of the extension of president Lahoud's term, the new government and resolution 1559. iMonthly in its Issue 30 published this survey (mentioned in the earlier section about the constitutional amendment), which also asked about disarming Hezbollah: " $49.5 \%$ of respondents are against disarming Hezbollah, versus $38.7 \%$ who support the move and $11.8 \%$ who are indifferent." Broken down into the different religious sects the results against disarming Hezbollah were as follows:

\begin{tabular}{|l|l|}
\hline $85.5 \%$ & Shiites against disarming the "Hezb" \\
\hline $63.1 \%$ & Sunnis against disarming the "Hezb" \\
\hline $27.4 \%$ & Maronites \\
\hline $21.3 \%$ & Catholics \\
\hline $55.5 \%$ & Orthodox \\
& \\
\hline
\end{tabular}

Table 7: \% of Lebanese Opposing Disarming Hezbollah. Source: Information International, 2004.

In April 19-24, 2006, Statistics Lebanon conducted a survey which asked, among other questions: do the respondents think that the Lebanese army should be the only armed forces deployed in the country? A majority of $78 \%$ answered "yes", $19 \%$ answered "no". The majority of those responding with a "yes" were Christians $(95.51 \%$ of the Christian respondents) while only $39.45 \%$ of the Shiites saw that the army should be the only armed forces deployed in the country. 
A few months later, between August 28 and September 1st, 2006, Statistics Lebanon interviewed a cluster sampling of 400 respondents residing in Beirut, Mount Lebanon, the South, North and the Bekaa valley, about their attitude towards the army. One of the questions in this survey asked the respondents if they thought the Lebanese army capable of defending Lebanon against Israel when given the necessary arms and equipment: $80.25 \%$ of the respondents believe the Lebanese army is capable of defending Lebanon if provided with the proper weaponry. That goes to the heart of the issue of the necessity of Hezbollah as a resistance movement and a protector against Israel. Having a strong army would take away the raison d'être of Hezbollah.

Later in the same year, from October 28 to November 1, Statistics Lebanon polled 400 citizens, spanning the whole country and including members from different age groups and socio-economic and religious affiliations about their support for the army. The results confirmed those of the earlier surveys, with $82 \%$ of the respondents approving of the Lebanese army getting support and weapons from the west and $67.75 \%$ of the respondents wanting the Lebanese army to secure the borders. The support came mostly from the Druze respondents $(92.31 \%)$, the Christians $(81.53 \%)$, followed by the Sunnis $(75.93 \%)$, with the Shiites having the lowest approval rate for the army deployment $(33.94 \%)$. It is important to note that this poll took place right after the Israeli invasion of the country in the summer of 2006 and its destructive war against Hezbollah.

A year later, in December of 2007, Information International conducted an 
opinion poll on the subject of the "Military Takeover, Hezbollah's Arms and Hezbollah and the Army." The results were published in iMonthly, issue 65 p. 2-8, December 1, 2007. The poll found that "the Majority of Lebanese support holding a referendum on Lebanon's identity." The poll was conducted October 22-28, 2007 on a sample of 2000 Lebanese. One of the questions addressed the respondents' attitude towards Hezbollah's arms. $59.4 \%$ of the respondents agreed with the statement that the arms were necessary to face Israel until the liberation of the Sheba'a farms, $34.3 \%$ did not agree with that statement and $6.3 \%$ did not know. $36.6 \%$ see the arms as not necessary after Israel's withdrawal from the South, $54.1 \%$ do not agree with that statement, and $9.3 \%$ did not know. The breakdown of these numbers along the religious confession lines is as follows:

\begin{tabular}{|c|c|}
\hline $91.6 \%$ & of the Shiites consider Hezbollah's arms as necessary to face Israel \\
\hline $22.5 \%$ & of the Druzes consider Hezbollah's arms as necessary to face Israel \\
\hline $34.6 \%$ & of the Catholics consider Hezbollah's arms as necessary to face Israel \\
\hline $53.8 \%$ & of the Orthodox consider Hezbollah's arms as necessary to face Israel \\
\hline $55.5 \%$ & of the Sunnis consider Hezbollah's arms as necessary to face Israel \\
\hline $42.8 \%$ & of the Maronites consider Hezbollah's arms as necessary to face Israel \\
\hline
\end{tabular}

Table 8: \% of Lebanese seeing Hezbollah's arms as necessary to face Israel, along religious rites. Source: Information International, 2007. 
Whether Hezbollah's arms reinforced the Shiites at the expense of other confessions in the country: $36.5 \%$ agreed that they did, $51.3 \%$ did not see it that way, and $12.2 \%$ did not know. On the question whether the fact that Hezbollah is armed played into the Syrian-Iranian agenda, the respondents on both sides of the issue were equally divided with the results as follows:

\begin{tabular}{|l|l|}
\hline $42.7 \%$ & $\begin{array}{l}\text { Do not see that Hezbollah's arms play into the Syrian-Iranian } \\
\text { agenda }\end{array}$ \\
\hline $42.7 \%$ & Do see that Hezbollah's arms play into the Syrian-Iranian agenda \\
\hline $14.6 \%$ & Do not know \\
& $\begin{array}{l}\text { Table 9: Do Hezbollah's arms play into the Syrian-Iranian Agenda? } \\
\text { Source: Information International, 2007. }\end{array}$
\end{tabular}

On the question if Hezbollah should merge with the regular Lebanese army the results were as follows:

\begin{tabular}{|l|l|}
\hline $62.2 \%$ & See that Hezbollah should merge with the regular Lebanese army \\
\hline $21.8 \%$ & Hezbollah should NOT merge with the regular Lebanese army \\
\hline $16 \%$ & Do not know \\
\hline
\end{tabular}

Table 10: Should Hezbollah merge with the army? Source: Information International, 2007. 
Looking at the responses to this question along confessions lines, only $49.1 \%$ of the Shiites agree with the idea of merging the "Hezb" with the army, compared with $78.4 \%$ of the Druze, $71.9 \%$ of the Sunnis, $56.7 \%$ of the Catholics, $57 \%$ of the Orthodox, and $61.4 \%$ of the Maronites.

On the other hand answering the question: Should Hezbollah be disarmed? The results were as follows:

\begin{tabular}{|l|l|}
\hline $8.5 \%$ & Yes, it should be disarmed \\
\hline $82.9 \%$ & No to disarming Hezbollah \\
\hline $8.6 \%$ & Do not know \\
\hline
\end{tabular}

Table11: Should Hezbollah be disarmed?

Source: Information International, 2007.

To the question, "In your opinion should the Lebanese army take control of the country for a temporary period?" $62.7 \%$ of the respondents answered affirmatively, $30.5 \%$ were against the idea, and $6.8 \%$ did not know. The $62.7 \%$ of the respondents agreed with the idea that the army should take over the control of the country for an interim period of time and only until the election of a president and the formation of a new cabinet are achieved. It is important to note that this survey (Information International, October 2007) took place at the heels of a disastrous sit-in in the downtown area that paralyzed the economy, and after a long stalemate in the election of 
a president on whom all factions could agree. Even though the idea of a military takeover contradicts all that constitutes a democracy, it was seen as a drastic, temporary but necessary evil to get the country on the right track again. It is important to mention here the survey described earlier in this paper and done by Information International in September 2001; the survey polled the Lebanese about the establishment of a military government: the answer then was an overwhelming No (77.7\%). Examining this fact through the behavioral component lens, we see that the actions did not follow the intentions of having a military government. The stalemate was resolved peacefully, and the sit-in dismantled shortly afterwards. The resolution came through negotiations among the elected officials and the political parties leaders.

By definition a democratically elected government has the monopoly on the arms and the leadership of the armed forces. That raises the issue of Hezbollah, its arms and its role in national defense through what is called "armed resistance." The results of a question in this poll about whether the "Resistance should have sole responsibility for national defense," only $3 \%$ of the respondents saw that Hezbollah should bear the sole responsibility for national defense. $51 \%$ see national defense as the responsibility of the government armed forces alone, with the remaining $45 \%$ seeing that it should be a joint effort between the government forces and Hezbollah. It should be noted, however, that $82 \%$ of the respondents who were Shiites said that the national defense should be a joint effort between the government armed forces and Hezbollah. 
The repeated disagreement among the different religious factions in Lebanon about the issues does not appear when the vital question of belonging to the country as a final homeland comes up. This topic was addressed in the following surveys.

\section{Lebanon "is a final homeland for all its citizens".}

Do the Lebanese feel allegiance first to Lebanon, to their family, to their religious group, or to the Arab nation? The following surveys studied this question. In July 26, 2006 the Pew Research Attitude Project studied the Muslims' attitude towards religion and politics in several Muslim countries in the Middle East, including Morocco, Jordan, Lebanon, and Turkey. Lebanon's Muslims came up as relatively secular and pro-Christian, but their support for "terrorism" and "anti-Semitism" was widespread. "Muslims in Lebanon are less likely to identify primarily with their religion, rather than with their country, with equal numbers saying they think of themselves first as Muslim (30\%) and saying they identify primarily as Lebanese (30\%)." Also, in 2006 Lebanese Muslims and Christians had positive attitudes towards each other: $86 \%$ of Muslims have "a favorable opinion of Christians, by far the highest rating of Christians by any Muslim public." $82 \%$ of Christians have a "positive view of Muslims." As for the importance of religion in their lives, $54 \%$ of Lebanese Muslims said it was very important, compared to $96 \%$ of Moroccans, for instance, or $86 \%$ of Jordanians.

To complete this picture, a November 2006 poll done by Information International in collaboration with the Social and Behavioral Sciences Department in the 
American University of Beirut found that the Lebanese follow their leaders and prefer peace, but are ready to fight for their family, country, and religion. The most highly endorsed identity was the family, followed by country, then religion. The Islamic Nation or the Arab world had the lowest ratings. The same study also revealed that the Lebanese favor their own confession (Maronites, Orthodox, Shiites, Sunnis, Druzes, etc.), "that they have strong leadership affiliation, are highly religious and they perceive their group to be threatened by other groups."

As mentioned in article a. of the Preamble to the Lebanese Constitution, Lebanon "is a final homeland for all its citizens." The 2005 Zoghby International study had, among others results, one that showed a majority of the respondents in Lebanon identify with the Lebanese identity first. This result is echoed by the 2007 Springhints -Mind the Gap survey on this specific question. Also, in the July 2006 Pew research project about the attitude of Muslims towards religion and politics, it is important to note the attitude of the Lebanese Muslims towards Lebanon as their homeland, and considering that they are Lebanese first and Muslims second. This is crucial because there has always been the issue of belonging at the heart of the existence of Lebanon as a country for both its Muslim and its Christian citizens. The Constitution, first, and the Taef accord, second, tried to resolve the issue of belonging by declaring Lebanon the final and undisputable country to its Christian citizens who were accused of allegiance to the West, especially France, and to its Muslim citizens who were accused of allegiance to the Muslim nation and especially to neighboring Syria. In later years the Christians were leaning in their 
political moves and allegiance to the United States, and the Shiites, who were increasing in number and in power, to Iran, in addition to Syria. That gives special importance to the results of the Pew research project.

Another important dimension of this particular project is its findings about the highly favorable attitude of Christians and of Muslims towards each other in Lebanon. That finding is reinforced daily in the Lebanese media with the statements and declarations given by various political figures from both religions on the importance they give to the presence of the other communities in Lebanon. They also express the value they attach to the participation and the contribution of the other confessions to the political life of the country. The statements in the media also underline the fact that the presence of the different religious confessions guarantees the liberties in the country.

The series of polls done between June of 2006 and April of 2008 by the LOAC, the IRI and Statistics Lebanon studied the attitude of the Lebanese towards national identity, voting and the democratic institutions. The first survey done in June 2006, shortly before the Israeli attacks, showed the Lebanese to have firm allegiance to their country first, and then to their religious rite. The same series of these surveys done from May 14 to June 11 of 2007 , found that "national identification continued to be strong and that " $71 \%$ of the respondents claimed they were Lebanese first, member of a religious group second."

We could conclude then that the surveys available to us dating back to 1995 , and 
throughout the Syrian occupation of the country, the assassination of the Prime Minister in 2005 and the Cedar Revolution years leading up to the parliamentary elections of 2009 - all of these surveys showed an attitude that, for the most part, considers the democratic regime as the "only game in town." Even with the particularities of the country and its deeply entrenched religious fanatism and political confessionalism, the Lebanese see themselves as citizens in a regime where the freedoms associated with democracy are prevalent and considered primordial, and where the numerous political parties play a major role, albeit a distinctive one in a traditional society. They value the elections and the accountability of the elected officials. Except for one religious faction, they want the army to be the only armed forces in the country. They have a very active civil society and consider important the participation in political life, such as elections, belonging to a political party or staying informed. The Constitution is to be respected and is seen as the protector of the democratic regime, not to be changed frivolously and on demand. Even though religious traditions and thoughts are deeply rooted in the minds and attitudes of the Lebanese, they do see the importance of a secular system. The multitude of religious rites in the country, all seventeen of them (eighteen if we were to count the dwindling numbers of the Jewish community), are not above the allegiance to the country; on the contrary, belonging to the country comes before the religious affiliation. The religious leaders from all sections do see the richness in this diversity, and multiply the calls to respect it, cherish it and live it in the societal arena. In the political arena, the calls from all factions are multiplying to do away with the 
confessionalism and to move towards laïcité in the government. The younger generation especially, as shown in the Springhints -Mind the Gap study, sees this need to keep religion away from the bureaucracy and the quotas in the government, while at the same time keeping this richness in the society. The prominence and abundance of political parties in the country is a sign of democracy. However these operate in and are a product of a traditional society, where the leaders do fill some of the roles of the elites in a western democracy, but do not fit the mold of the western leaders, nor are they held to the same accountability standards.

It bears repeating at this point that the surveys used were done by different companies or study groups at different times, using different instruments. Even though we did not have control over the quality of the surveys, or the ways the questions were phrased, these could still be useful in guiding us towards a certain path and towards better controlled surveys in the future. 


\section{The Constitutional Variable}

To be able to say that the constitutional component of a consolidated democracy is present, according to Linz and Stefan's definition, we should be able to state that conflicts are "habitually resolved within the dictates of laws, procedures and institutions established in a mutually agreed upon process “ (Linz \& Stepan, 1996: 6). To determine that, this study will first look at the Lebanese Constitution following the guidelines and indexes provided by S.E.Finer's Comparing Constitutions. That will allow for a study in theory of the Constitution to see if it can be described as democratic when compared to constitutions from countries known as such. Along with the study in theory, a look at how the Lebanese Constitution is applied in practice would lead to a conclusion whether or not we could say that the Linz and Stepan's definition of the constitutional component in a consolidated democracy does apply. Are conflicts in Lebanon "habitually resolved within the dictates of laws, procedures and institutions established in a mutually agreed upon process “(Linz \& Stepan, 1996: 6). Also, when looking at how the Constitution is applied and conflicts resolved, we often step out of the purely constitutional component and into the realm of the behavioral and the attitudinal components of a consolidated democracy as well.

Finer compared the constitutions of the USA, France, Germany, Russia, and that of the United Kingdom, even though the UK's Constitution is rather "indeterminate, indistinct, and unentrenched" (p. 40). Finer does note the differences between these constitutions as due to what he termed "autobiographical elements in the history" of each 
of them. These constitutions, however, do have much in common, according to Finer: "Each is democratic in the sense that it makes the legislature and the executive ultimately dependent on popular vote, and each gives the final say to a majority of those entitled to vote, though there are important differences in the kinds of majority needed to carry the day" (Finer, 2006: 39). Finer did recognize the important fact that each constitution is the result of different historic moments and events, but also that "each text operates within a matrix of custom, convention, case law, and cautious compromise" (Finer, 2006: 39).

The criteria offered and used by Finer look at how the following elements are addressed in a certain constitution:

- Adoption and Amendments,

- General Features, which include: length and preambles to the Constitution, governance, voting generally, and federalism (which does not really apply in the case of Lebanon).

- The Judicial Branch,

- Emergency Powers,

- International Affairs,

- Human Rights.

How does each of these criteria figure in the Lebanese Constitution? 


\section{Adoption and Amendments.}

The Lebanese Constitution was promulgated in 1926 at the creation of the country of Lebanon by the League of Nations after the conclusion of World War I. Later, in 1943, the Constitution was adopted as the law of the land at the independence of the country from the French Mandate. The Taef Agreement of October 1989, which put an end to the fifteen-year war, brought some amendments to the 1926 Constitution.

\section{Amendments.}

According to Finer, "the provisions on the means by which a constitution may be amended are of both judicial and political importance: they are themselves an exercise of the constituent power in spelling out how its own creation may be changed; they divide the amending power among people, legislature, and executive, or between a federation and its components; and they may express basic values" (Finer, 2006: 13). The Lebanese Constitution (Part C, Procedural Provisions, Chapter II, articles 76 through 79) lays down the procedure for amending the Constitution. It is a process that involves the Executive branch represented by the President of the Republic and the Cabinet of Ministers, and the Legislative branch or the Parliament. To amend the Constitution, a draft law is presented by the Cabinet and at the proposal of the President. A two-third majority of the parliament is required both for the discussion of the proposal and for the vote. Time limits and strict conditions apply which makes the process quite complex and protected from misuse by one branch of the government or one person. The safeguards built into 
the Constitution to protect it from being lightly and repeatedly amended are a manifestation of the deeply entrenched respect of the Constitution within the citizenry and their elected representatives.

In a consolidated democracy, by definition, conflicts are " habitually resolved within the dictates of laws, procedures and institutions established in a mutually agreed upon process" (Linz \& Stepan, 1996: 6). An important manifestation of that aspect of a consolidated democracy, is the fact that throughout the long years of war, occupation and void in the government, there was no coup d'état! There was no attempt by any of the militias or the army generals to usurp the control of government by force. That, in itself, speaks clearly to the value the Lebanese give to the democratic regime, and particularly to the Constitution and the role it plays in providing a mutually agreed upon process to solve conflicts or to govern the country. Even throughout the Syrian occupation, the occupying power always forced changes disguised under the cover of a Constitutional amendment. One example is the renewal in 2004 of the mandate of the pro-Syrian President of the Republic. The renewal was done by an amendment to the Constitution imposed by the Syrian regime upon the majority of the Parliament members. As reported at the time by the New York Times in articles dated August 29, 30, and September 3, 2004, the protest against the renewal was loud, but it was forced through nonetheless, and it was done according to the laws of the land: a forced amendment to the Constitution that allowed for a one-time additional three-year term for the pro-Syrian President, Emile Lahoud. The Constitution dictates a one-term, non-renewable, of six years for the 
President of the Republic. An amendment to the Constitution requires a two-thirdmajority vote of the 128 Parliament members. The Amendment passed by a 96 to 29 vote. According to the New York Times article "The outcome was not unexpected here, where Syria, with 20,000 troops still in the country, has called the final political shots since the end of the 15-year civil war in 1990." In an article dated September 3, 2004, and published September 4, John Kifner reported in the New York Times that "As expected, Lebanon's Parliament on Friday rubber-stamped Syria's order to keep its handpicked president in office, voting in an extraordinary session to amend the Constitution to give him three more years." The majority of the Lebanese people, however, were against the extension of the President's term. A survey of a sample of 1000 people of all political, religious and social backgrounds showed that $65 \%$ opposed the renewal, and "84 \% of the Lebanese believed that foreign and outside parties had dictated the results of presidential elections." (A survey done by the Lebanese magazine Al-Sharia was quoted in the John Kifner New York Times article published on September 4, 2004. The weekly magazine published the survey in its Friday issue, the same day the election in the Parliament was to take place on September 3, 2004). The electoral campaign had started according to the norms and the democratic practice of announcing the different candidates running for the post of the Presidency. The campaign of Boutros Harb, a Maronite MP had started by officially announcing his candidacy in the Parliament in early August (An-Nahar, August 4, 2004 : 5). He was followed by several other Maronite candidates vying for the highest office of the land. The An-Nahar reported in 
its issues, starting in mid-August, many protests and calls for the refusal of the renewal and of the amendment to the article 49 of the Constitution. Article 49 dictates one sixyear term for the president and states that "he may not be re-elected until six years after the expiration of his last mandate." The newspaper, in its August 29, 2004 issue, reported on the "10 minute" Council of Ministers session to send the one-time constitutional amendment to the Parliament to be ratified in an exceptional session of the Parliament on August 30. It also reported that the Prime Minister Rafik el-Hariri, known for his opposition to the Syrian regime and its influence in Lebanon, had left on a trip outside the country after the ten-minute session of the Council of Ministers (An-Nahar, August 29, 2004). The council of Maronite Bishops published a statement calling the amendment unconstitutional and decrying the "Syrianization" of the country (An-Nahar, September 2, 2004), echoing the views of many other Lebanese personalities. The AnNahar reported in its September 4, 2004 issue on the renewal that resulted from a 96-29 vote to renew the term.

Another example of the entrenched respect of the Constitution and of solving conflicts according to the established laws, took place during the Syrian occupation. Any resolution or action was done in a way that made it seem as if it were done according to the Constitution. The Syrian regime resorted to naming new members of the parliament instead of running new elections. That runs contrary to any democratic principle. To give it a cover of legitimacy the Syrian regime forced the amendment of the Constitution to allow for a one-time filling of the empty seats in the Parliament, by naming the 
deputies. Three hundred forty eight "candidates" were nominated, and the Government chose 41 of them to fill the seats that were either empty because of death, or were added by the Taef Accord. The naming was met by loud criticism and protests mostly by the Christian anti-Syrian political leaders (An-Nahar, April 5, 1991) and by a demonstration against the naming of deputies (An-Nahar, March 29, 1991).

The above instances illustrate not only the constitutional variable, but attitudinal and behavioral ones as well. The actors behaved in a manner that fits under the cover of the Constitution; a coup d'état could have easily taken place on more than one occasion, but that did not happen. Instead, great lengths were followed to control the government in a manner that seemed to stay under the umbrella of the established laws.

\section{General Features of the Lebanese Constitution}

The general features that Finer considered when comparing constitutions include whether or not a given constitution has a preamble, its length, the type of governance it dictated, how it addressed voting generally, and federalism. In Lebanon federalism is not an issue; however, the democracy in Lebanon is a Consociational democracy, and that too is regulated in the constitution and its preamble.

\section{Preamble and length.}

The Lebanese Constitution contains a hundred and two articles. In its preamble, it declares the country to be a "sovereign, free, and independent country." It also declares 
Lebanon to be a "parliamentary democratic republic based on the respect for public liberties, especially the freedom of opinion and belief, and respect for social justice and equality of rights and duties among all citizens without discrimination." (Preamble, article c.) $^{9}$

\section{Governance.}

The Lebanese Constitution, in article c) of its preamble, declares the country as a "parliamentary democratic republic" where "the people are the source of authority and sovereignty; they shall exercise their powers through the constitutional institutions"(article d.), and with a political system "established on the principle of separation, balances, and cooperation amongst the various branches of Government." (article e.)

The representatives of the people are elected by the people every four years, and they form the Chamber of Deputies. It is made up of 128 members, divided equally between Christians and Muslims and proportionally among the different confessions and regions. The Deputies, in turn, elect the President of the Republic. The Prime Minister would be a Sunni Muslim, a leader from the coalition or party that won the majority in the elections, and whom the President of the Republic would ask to form the new

${ }_{9}^{9}$ It should also be noted that Lebanon, represented by Mr. Charles Malik as president of the United Nations Human Rights Commission, was one of the writers and original signers of the International Bill of Rights signed into effect at the UN on December 10, 1948. 
Government. The newly selected Prime Minister is required to have consultations with all the leaders and prominent members of the political parties and coalitions to nominate ministers to the new Government.

The election laws, however, do change every so often, depending on the parties in power. They mirror the maneuvering that takes place in the United States for instance, with the "gerrymandering" and manipulating of the districts and their limits to benefit one party over the other. The latest parliamentary elections took place following the laws of 1960, a decision that followed much deliberation, studies, and reports from specialized commissions. In the opinion of many, going back to the 1960 laws is actually a step forward toward equity in representation, compared to the electoral law applied in 2000, which reeked of Syrian influence and interference. Even with the 2000 law in place, the fact that elections actually took place and the laws applied, shows the importance of the constitutional indicator in Lebanon. In 2000, and during the Syrian presence in the country, parliamentary elections were actually held according to a tailor made electoral law that serves the interests of Syria and its supporters and sympathizers in Lebanon. It raised a lot of protest from the anti-Syrian camp to the point of their boycotting the elections. Instead of ignoring the laws altogether and not calling for elections, the electoral law was written in a way and the promulgation process manipulated in sort as to rig the results, while giving the impression that the democratic elections and process were actually followed. This manipulation was made necessary by the fact that the occupation forces realized that the elections had to take place, and to preserve, even in appearance, 
the idea of a democratic process dictated by the laws of the land. That illustrates the importance the Lebanese attach to the democratic process, and even when they are aware of and dissatisfied by the apparent manipulation of the laws. These elections were the topic of one of the surveys mentioned in the Attitudinal component section, and showing the Lebanese believing in the importance of elections, and participating in them, even when they knew of the Syrian interference.

As for the separation of powers, Finer turns to the French republic, where "The 1789 French Declaration proclaimed that a society which lacked the separation of powers had no constitution at all" (Finer, 2006: 21). In the Lebanese Constitution, the separation of the different branches of government is described in the text itself, but figures also in line e of the Preamble which states that "the political system is established on the principle of separation, balance, and cooperation amongst the various branches of Government." In addition to describing the separate roles of each branch of the government, the Constitution also lists ways in which each branch checks the works of the others as shown in the articles below:

- Article 35 states that the meetings of the Chamber are public.

- Article 37 gives every "deputy the absolute right to raise the question of noconfidence in the government during ordinary or extraordinary sessions.

- Article 52 gives the President of the Republic the right to negotiate international treaties in coordination with the Prime Minister. The treaties that concern major 
national interests or which cannot be reviewed every year, are not considered ratified until they are approved by the Parliament.

- Articles 57 and 59 give the President the right, albeit limited, to veto a bill and to adjourn the Chamber for a period not exceeding one month during the same session.

- Article 65 gives the Council of Ministers the power to dissolve the Chamber of Deputies if it, "for no compelling reasons, fails to meet during one of its regular periods and fails to meet throughout two successive extraordinary periods, each longer than a month, or if the Chamber returns an annual budget plan with the aim of paralyzing the Government."

- Article 68 gives the Chamber the vote of no confidence in a minister or in the whole government.

- Article 70 gives the Chamber the right to impeach the Prime Minister or Ministers for "high treason or for serious neglect of their duties. The decision to impeach may not be taken except by a majority of two thirds of the total membership of the Chamber."

- Article 20 declares the judges independent in the exercise of their duties and their decisions are rendered in the name of the Lebanese people.

- It is important to mention Article 19, which establishes a "Constitutional Council to supervise the constitutionality of laws and to arbitrate conflicts that arise from parliamentary and presidential elections. The President, the Speaker of the 
Parliament, the Prime Minister, along with any ten Members of Parliament, have the right to consult this Council on matters that relate to the constitutionality of laws." Heads of religious communities also have the right to consult the Council on matters concerning laws relating or affecting freedom of religion and of religious practices and education.

All of the above articles ensure the fact that the executive branch of government answers to the elected Parliament, and in a few clearly stated instances the Parliament could be dissolved by the executive branch. The President checks the performance of the ministers, names the Prime Minister after recommendations from the elected Deputies, and could suspend the Parliament for a month. He has Veto power over the laws, and the international treaties he negotiates have to be ratified by the Parliament. The Parliament meetings are open to the public and often broadcast on local television stations. Apart from all this stands the Judiciary branch, whose judges are independent. Also independent is the Constitutional council that checks the constitutionality of the laws. The separation of the powers and the checks and balances among them is one of the major components of a democratic regime as defined by the literature on the subject.

In addition to the separation of powers, the mention of political parties in the constitution as political actors figures in the French, German and Russian Constitutions. It does not appear in the United States' constitution. They are mentioned in the 1993 Maastricht amendments as a "factor for integration within the Union" (Finer, 2006. p.21). In Lebanon, and even though the number of political parties is close to eighty, depending 
on the current events or the date, there is no mention of political parties in the Constitution. While the Constitution guarantees the freedom of speech, of assembly, and of conscience, it does not mention political parties as a basis for political action or for seats distribution in the Parliament or in the government bureaucracy. Instead, the seats are distributed following proportional religious, confessional and regional representation (article 24, Electoral Laws). We do see, however, that the political parties play the role described earlier in this thesis. Parties are an important part of the process: not only do they play the role of mass-elite linkage, but they also have an edge over the other civic associations in that they are the only groups that aim to have elected representatives in the government. The mere existence of parties is a proof of the tolerance of conflict, of different views and of opposition, all of which are manifestations of a democratic system (Eldersveld, 2000). They could start as a mirror image of social powers, but gradually shift to addressing political issues and to acting as a recruiting tool, not just to elites, but also to the "working elites" (Eldersveld, 2000). Most importantly, and to alleviate the pressure from Huntington's "mass participation," they act as a "transmission belts for pressure from lower down" (Daalder, in LaPalombara ed. 1966: 71). Parties can exist without democracy, usually in single-party systems such as the communist party in the former USSR, or the Baath party in Iraq or in Syria. The opposite, however, is unimaginable: we cannot have democracy without political parties. In Lebanon there are, at last count, eighty different political parties, currents and coalitions. The Lebanese have conflicting views and feelings about the political parties, as shown in the surveys 
mentioned in the section about the Attitudinal component. Their presence, however, is taken for granted, and their role in the political life of the country is manifested in the coalitions they form to be part of the government and to pass new laws. They also present candidates to the elections; some are well known and some are newcomers to the political scene but are benefiting of the access the party offers to the electoral process. Their presence is made possible by the freedoms of expression, of thought and of assembly guaranteed by the Constitution.

The Consociational democracy in Lebanon had some of its major elements adopted as a National Pact rather than as a declared part of the Constitution. That, however, did change when the Taef accord made the division of power among the different religious confessions part of the written constitution. The Taef Accord put in writing into the Constitution what was a Pact, an agreed upon common law. The President of the Republic is to be a Maronite Christian, the Prime Minister a Sunni Muslim, the Speaker of the Parliament a Shiite, the deputy Prime Minister a Greek Orthodox, and the Deputy Speaker of the Parliament also a Greek Orthodox. The leadership posts in the armed forces and the police are also shared among the different religious confessions. The Taef accord divided the number of deputies in the Parliament equally between Christians and Muslims.

The Consociational democracy was meant to be a temporary form of governance in the country to prepare the way towards a regular democracy along the lines of what 
happened in Switzerland. An attempt to get to that stage in Lebanon starts by abolishing the political confessionalism and aiming at distributing powers and political positions according to competence and merit. Article 95 calls on the Parliament to start working towards abolishing political confessionalism by creating a committee headed by the President of the Republic, and including the Speaker of the Parliament, the Prime Minister, and "leading political, intellectual and social figures." The committee is to "study and propose the means to ensure the abolition of confessionalism to the Chamber of Deputies and the Ministers, and supervise the execution of the transitional plan." That has yet to take place. We could also see from the surveys mentioned in the section on the Attitudinal component that most Lebanese would rather see the political confessionalism replaced by a secular system. A few steps, however, have being taken and are gradually being implemented. A symbolic one is the elimination of the religious rite on the identity cards. That was one of the changes resulting from the amendments made to the Constitution by the Taef (or Taif) accord:

“ The Taif Agreement introduced thirty-one important constitutional amendments which were approved by the Lebanese Parliament on August 21, 1990, and signed into law by President Elias al-Hraoui on September 21, 1990. The reforms did not fundamentally alter the political structure, which is still predicated on political sectarianism. The changes aimed at creating a new and more equitable confessional formula (i.e., one that distributes power fairly among all confessional communities), but although the Agreement stated that the abolition of confessionalism was a national goal, no specific deadline or timetable was provided for its actualization 
(An-Nahar 1992). The Agreement was decisive in determining the Arab identity of Lebanon, emphasizing that Lebanon was an independent, sovereign, free country and a "final homeland" for all Lebanese. Second, it confirmed the unity of Lebanon. Third, it defined the nation's political system as a parliamentary democracy, based on the principles of separation, balance, and cooperation among the various branches of government. Fourth, it clearly defined the socio-economic system as a free economy favoring individual initiative and the right to private property. However, it also emphasized the necessity for balanced and even development in all the regions to insure a form of social equity. Fifth, it stated that the abolition of political sectarianism constitutes a basic national goal to be achieved according to a gradual scheme. " (Krayem in "The Lebanese Civil War and the Taif Agreement" as downloaded from ddc.aub.edu.lb/projects/pspa/conflict-resolution.html).

One more of the general features of a constitution is its regulation of voting in the country. In Lebanon, the issue is a little different from the simple majority usually adopted in democracies. In a Consociational democracy the tyranny of the majority is to be avoided to allow for all segments of society to participate in the governing of the land.

\section{Voting.}

As described by Finer, "the machinery of democracy often functions by way of voting, and the majority carries the day" (Finer, 2006: 27). The majority is usually and in ordinary matters the simple majority of those who do vote (Finer, 2006). In the Lebanese Constitution article 21 gives every citizen who has completed his or her twenty-first year 
the right to vote, "provided he fulfills the conditions laid down in the electoral law." The candidates are more often than not members of political parties and are running as such and following a platform dictated by their political party's philosophy. Not only are the candidates members of political parties, but the voting also happens according to the party line. The last parliamentary elections, which took place in June of 2009, did have a few independents running for election. The results were surprising and different from the elections that took place in the last fifteen years, in the sense that a new majority belonging to new coalitions among the political parties was elected into the parliament. The Lebanese surveyed in 2004 by Information International favored elections, believed in the importance of elections, and even though most of them saw Syrian intervention in the elections, they still believed (2000 Information International poll) that they were worth having, and a majority of the citizens did vote. This rather fits under the attitudinal variable, and it is discussed in that section too, but it reinforces the idea that the Constitution of the land lays down the process for a democratic life and that it is being followed. It is also a law that is respected by the citizens, who do notice when it is being infringed upon or manipulated, as it was during the 2000 elections under the Syrian occupation.

One more important component in a democracy is an independent judicial branch, separated from the struggles of politics, protected by the law of the land, and playing an important role in the checks and balances of the three branches of government, and 
ensuring the constitutionality of the laws. How did the Lebanese Constitution address the Judiciary and how does that play out in practice?

\section{The Judicial Branch.}

"When it comes to the judiciary, separation of powers is taken quite seriously" (Finer, 2006: 28). Also, to ensure the constitutionality of laws, a special tribunal is created and given the power to monitor and judge the constitutionality of the laws that come out of the legislative branch. In the Preamble of the Lebanese Constitution, article e. declares that "The political system is established on the principle of separation, balance, and cooperation amongst the various branches of Government."

Article 19 creates a "Constitutional Council" to "supervise the constitutionality of laws and to arbitrate conflicts that arise from parliamentary and presidential elections." Heads of the different religious communities can consult the Council about laws pertaining to personal status and the freedom of religion. The Council is governed by a special law.

Another way to check the Executive branch given to the Judicial and the Legislative branches is the creation of the "Supreme Council" in article 80 of the Constitution. It is made up of "seven deputies elected by the Chamber of Deputies and of eight of the highest Lebanese judges, according to their rank in the judicial hierarchy, or, in case of equal ranks, in the order of seniority. (...) A special law is to be issued to determine the procedure to be followed by this Council." 
Article 20 guarantees the independence of the Judicial Branch in all of its tribunals of different levels and jurisdictions. "It functions within the limits of an order established by the law and offering the necessary guarantees to judges and litigants. The limits and conditions for the protection of judges are determined by law. The judges are independent in the exercise of their duties. The decisions and judgments of all courts are rendered and executed in the name of the Lebanese people."

How does this law play out in reality? The Judiciary in Lebanon before the war was a respected area and functioning according to the established laws and procedures, amid a culture of public and individual freedoms. The fifteen years of war were followed by the Syrian occupation which put an end to an independent trustworthy judiciary. According to a report published in the Daily Star in the summer of 2005, "It took years to undermine Lebanon's judiciary, and much of the damage was done during Syria's occupation, when the occupier stripped all of the Lebanese state's institutions of any real legitimacy and authority. Lebanon's judiciary was rendered nearly useless during the tenure of former Prosecutor and Justice Minister Adnan Addoum. His willingness to subject the Lebanese judiciary to foreign domination" (Quilty, 2005) was notorious and conspicuous. Files were created, evidence manipulated, and charges trumped up against those who dared criticize the government or the Syrian regime. One of the notoriously accused and convicted citizens was one of the anti-Syrian leaders and warlords: the charges were not related to the war events, the evidence made-up, and the punishment excessive. In addition to the prison sentence, his political party was banned. Multiple 
political assassinations among the ranks of the anti-Syrian politicians and well-known and outspoken journalists took place without any investigation or effort to catch the perpetrators (Quilty, 2005). The Judges themselves became victims: four judges were killed in the courthouse in June of 1999, and their killers remain unapprehended. Quite often also the judges were subjected to threats and pressure in high profile cases, and reported in the media (the affair of the Al-Medina bank is a case in point). These instances and many others led to the sapping of the confidence and esteem of the judicial system members and the confidence of the people in a capable and independent judiciary (Quilty, 2005).

The Higher Judicial council is formed partly of members elected by the judges themselves, and the other half named by the executive and legislative branches. That limits the independence of the Council. However, The public's confidence in the judicial system is changing from what it was during the Syrian occupation, and many attempts at giving the judicial branch more independence from the political powers are in the works. In a study done for the Arab Center for the Development of the Rule of Law and Integrity based in Lebanon, and looking at the state of the Judiciary in Lebanon, Elias Chalhoub has made many recommendations to bring the Judiciary in the country to a more solid place. Some elements of his report mention the many studies and drafts for new laws to protect the judges and ensure the independence of the judiciary from the executive and legislative branches. These, however, are still in parliamentary commissions awaiting approval or ratification. The fact that the Judicial branch is headed 
by the minister of Justice makes the judiciary vulnerable to political tendencies and pressures. One more practice that impedes the independence of the judiciary in Lebanon as mentioned by Chalhoub, is the fact that the Constitution does allow for special courts, including military courts that are allowed to try civilians and were widely used during the Syrian occupation. Also in the Consociational democracy of Lebanon, and with the segments having their rights to manage the personal matters of their members in an autonomous manner, religious courts hear cases of personal issues such as marriage, divorce, inheritance, and education.

\section{Emergency Powers.}

In addressing emergency powers, Finer sees that "The greater the constitutional commitment to a Bill of Rights, the more difficult it is to frame emergency powers. The following issues have to be resolved: the events or circumstances which count as an emergency, the body which can decide whether these circumstances exist; the body which can exercise emergency powers; the extent to which these powers can contravene normal rights and liberties; and the procedure for and the supervision of their exercise" (Finer, 2006: 32). The Lebanese Constitution gives the power to declare the state of emergency and to terminate it to the council of ministers. Declaring the state of emergency is considered a basic national issue requiring a majority vote of two thirds of the members of the Cabinet. 
Article 49 makes the President of the Republic the head of state and "the symbol of the nation's unity. He shall safeguard the constitution and Lebanon's independence, unity, and territorial integrity. The President shall preside over the Supreme Defense Council and be the Commander-in-Chief of the Armed Forces which fall under the authority of the Council of Ministers."

\section{International Affairs.}

Finer, in comparing the constitutions of the United States, France, the United Kingdom, and Germany, finds that "in all the constitutions, the general conduct of international affairs in peacetime is, for obvious practical reasons, confined to the executive. The Head of State appoints and receives ambassadors and ratifies treaties negotiated by the executive, although the constitution may require the President to obtain the consent to ratification of the legislature or some branch thereof" (Finer, 2006: 34).

Article 52 of the Lebanese Constitution states that "The President of the Republic negotiates international treaties in coordination with the Prime Minister. These treaties are not considered ratified except after agreement of the Council of Ministers. They are to be presented to the Chamber whenever the national interest and security of the state permit. However, treaties involving the finances of the state, commercial treaties, and in general treaties that cannot be renounced every year are not considered ratified until they 
have been approved by the Chamber." International agreements and treaties are considered "basic national issues," and therefore adopting them requires the approval of two thirds of the members of the Council (article 65). In the Chamber, quorum consists of "the majority of the total membership." "Decisions are to be taken by a majority vote. Should the votes be equal, the question under consideration is deemed rejected" as per article 34. Article 53 states that the President of the Republic "accredits ambassadors and accepts credentials of ambassadors."

\section{Human Rights.}

In his comparison of the four constitutions, Finer finds that they all mention human rights. Some mention human rights in the preamble or the first few chapters, add the Bill of Rights or have amendments to the constitution to ensure respect for human rights.

In the Lebanese Constitution, the respect and protection of human rights are stated clearly in the Preamble and again in articles of the Constitution. In the Preamble, article b. states that Lebanon is "a founding and active member of the United Nations Organization and abides by its covenants and by the Universal Declaration of Human Rights. The Government shall embody these principles in all fields and areas without exception." Article c. declares Lebanon to be a "parliamentary democratic republic based 
on respect for public liberties, especially the freedom of opinion and belief, and respect for social justice and equality of rights and duties among all citizens without discrimination." Article f. describes the economic system as "free and ensures private initiative and the right to private property." Article i. gives every Lebanese the "right to live in any part of (the Lebanese territory) and to enjoy the sovereignty of law wherever he or she resides. There is no segregation of the people on the basis of any type of belonging, and no fragmentation, partition, or colonization."

To ensure the respect of private property and that there will be no taxation without a law, articles 81 and 82 of the Constitution dictate that no tax shall be levied, collected, or modified except by a "comprehensive law which applies to the entire Lebanese territory without exception." Article 14 proclaims the sanctity of one's residence: "the citizen's place is inviolable. No one may enter it except in the circumstances and manners prescribed by law." "Rights of ownership are protected by law. No one's property may be expropriated except for reasons of public utility in cases established by law and after fair compensation has been paid beforehand" (Article 15).

All citizens who have completed their twenty-first year have the right to vote (article 21 of the Constitution). Article 7 declares "all Lebanese equal before the law. They equally enjoy civil and political rights and equally are bound by public obligations and duties without any distinction." Article 8 protects individual liberty and guarantees it and guarantees the fact that no one shall be arrested or imprisoned "except according to 
the provisions of the law. No offense may be established or penalty imposed except by law." Article 9 protects the freedom of conscience. "The state in rendering homage to the Most High shall respect all religions and creeds and guarantees, under its protection, the free exercise of all religious rites provided that public order is not disturbed. It also guarantees that the personal status and religious interest of the population, to whatever religious sect they belong, is respected." Article 10 guarantees the freedom of education "insofar as it is not contrary to the public order and morals, and does not interfere with the dignity of any of the religions or creeds." It also protects the rights of the different religious sects to have their own schools, "provided they follow the general rules issued by the state regulating public instruction." The Lebanese Constitution guarantees and protects the rights of all segments of the Lebanese society to participate in the government. That includes those groups whose philosophy is in stark contradiction with the principles of democracy. Linz \& Stepan addressed this same idea when studying the democracy in Spain. Allowing all existing political forces to participate in the political process, including those against democracy, creates an inclusive society. It avoids the resentment and the persecution and jailing that result from banning and disallowing certain factions (Linz \& Stepan, 1996: 97). That all-inclusive government is the "grand coalition" in Lijphart's “consociational democracy." In Lebanon, this inclusivity gives Hezbollah the right to have elected deputies in the Parliament and appointed ministers in the Cabinet. Hezbollah is as an Islamic resistance movement and a political party whose 
philosophy is based on the application of the Islamic "Shari'a" or the Islamic law as dictated by the Koran and the Hadith.

All citizens have the right to hold public office without any discrimination, and only according to one's merit (article 12). Article 13 guarantees the freedoms of expression, press, association, and assembly. As a result of this guarantee, the NGOs in Lebanon have flourished. To start an NGO in Lebanon, the only requirement is to simply inform the Ministry of Social Services. No permit is necessary. It is very telling that this practice changed during the Syrian occupation of the country: a permit and a background check became required before an association or an NGO could operate. That was reversed when the Syrians got out of the country. In Lebanon, the NGOs still play a major role in providing services, but also in creating vehicles for a very active civic society. These NGOs contribute $\$ 300$ million yearly to the national economy, not counting the manpower and production by the volunteers and employees. They operate 760 clinics and health centers out of the total of 860 in the country (Mhannah, 2001). There are at least 300 NGOs operating in Beirut alone, among which fifty are considered to be operating with more than ten employees each. Their yearly budget combined reaches between $\$ 250$ and $\$ 300$ million. These NGOs fulfill a wide range of needs. In addition to the charitable organizations, orphanages, and local training centers and clinics, they include a large number of advocacy groups and of syndicates and professional organizations. Investing in the human capital is another major goal. They 
aim at developing human resources and helping "people, for people, through people" (ElHusseini \& Douaihy, 1999).

The protection of the freedom of expression and of the press led to the proliferation of the printed press (at least twelve daily newspapers are published in the country) and of the electronic media. There are numerous television stations: there is the public station run by the government, but it is no competition to the private stations. Quite a few of these stations have a distinct political affiliation and belong to one of the political parties. They operate freely and are easily accessible. The same is true for the radio stations. The Internet is readily and freely available. The Lebanese population is computer literate and uses the social networks as easily and commonly as in the US for instance.

Basing the study of the Lebanese Constitution on Finer's criteria and following his guidelines, we conclude that all of the elements Finer considered crucial in the Constitution of a democratic regime figure prominently in the Lebanese Constitution. The Constitution provides the citizens with a way to resolve conflicts "within the dictates of laws, procedures and institutions established in a mutually agreed upon process " (Linz \& Stepan, 1996: 6), at least in theory. In practice there are some challenges that were mentioned above and which will be discussed further in the section set aside for the Challenges faced by democracy in the country. 
It bears repeating that even though this section dissected the Lebanese Constitution according to Finer's criteria and to see if the citizens resolved conflicts "within the dictates of laws, procedures and institutions established in a mutually agreed upon process " as defined by Linz and Stepan, it is quite artificial to separate the constitutional component from the attitudinal or the behavioral ones. They are all affected by each other and none of them is taking place in isolation of the other factor.

From the above study of the constitutional, behavioral and attitudinal factors of the Consociational democracy in Lebanon, we could conclude that the democracy is consolidated in some areas, but still is facing serious challenges. Freedom House rating for 2009 for Lebanon was as Partly Free with a Political Rights Score of 5 and a Civil Liberties Score of 4. That rating improved in 2010 to a Civil Liberties score of 3. The country is qualified as Partly Free in 2010. The Polity IV report for 2009 gave Lebanon an Effectiveness score of $4 / 13$ and a Legitimacy score of 6/12. The Political Effectiveness score is $1 / 4$ (low fragility) and a Political Legitimacy score of 4/4 (high fragility). The country is described as democratic, and the scores for economic legitimacy and efficiency are both 0/10 meaning "no fragility". The country has an overall fragility index of $10 / 25^{10}$. Being classified as a partly free or a partly fragile regime evidently

10 "A country's fragility is closely associated with its state capacity to manage conflict; make and implement public policy; and deliver essential services and its systemic resilience in maintaining system coherence, cohesion, and quality of life; responding effectively to challenges and crises, and continuing progressive development." (Polity IV Global Report 2009.) 
means that there are still challenges to overcome. Some of these challenges are a direct result of external factors, due to the Israeli occupation of Lebanese territories, of the presence of Palestinian refugees in the country, and of the interference of many neighboring countries in the internal affairs of Lebanon. Other challenges are internal and are discussed in the following section, which addresses the sub-question posed by this thesis. 


\section{Challenges to the Consolidation of Democracy in Lebanon}

The above analysis shows that there are challenges facing consolidation of democracy in Lebanon. Some of the internal challenges result from the nature of the democracy in the country: a Consociational democracy trying to bring together into the government many segments that are at odds sometimes in their vision of the country and sometimes in their vision of democracy in general. Other than the nature of the Consociational democracy itself, there is the fact that Lebanon is still very much a traditional society where family ties and religious traditions figure strongly in the social and political arenas. In addition to the internal factors, the democracy in the country also faces challenges from external sources.

\section{The External Challenges}

The external challenges are a result of the country's geographical location and the regional conflicts. The Israeli occupation of Palestinian territories sent thousands of Palestinians to refugee camps in Lebanon. Their large numbers and subsequent interference in Lebanese affairs wrecked havoc in the country and they were at the heart of the fifteen-year war. The Palestinians were major players in that war from 1975 to 1989. Their numbers tipped the balance in favor of the Sunni camp and a large number of them were given the Lebanese citizenship to be able to vote and strengthen the Sunni camp in politics. Their presence as a result of the Israeli occupation of their land badly affected the stability of the country and the delicate balance of power within it. The 
Israeli occupation of Syrian and Lebanese territories is the excuse for the existence of an armed militia in the country, known as the Hezbollah. Hezbollah is seen by the Shiites mostly, as an Islamic resistance to the Israeli occupation of Arab land in general and Lebanese territory in particular. The strong ties that the resistance has with Iran and Syria weaken the sovereignty of the legitimate government in Lebanon. Those ties open the door for interferences from both of these authoritarian regimes into the affairs of Lebanon. One example of that is the war that Hezbollah caused in the summer of 2006 against Israel. That war was started without the consent of the elected government and without going through the proper channels in a democratic regime. Frequent attacks by Israeli warplanes or tanks on the country show the elected government as powerless and put the militia in a stronger light. It also gets in the way of any normalization and prosperity in a country that depends mostly on tourism and financial services, neither of which can prosper in a constant state of war or instability. In addition to that, the daily news are chockfull of reports about visits to embassies or of special envoys from the United States, France, Qatar, Saudi Arabia, Syria and Iran to name the more prominent ones. Interferences of Syrian authorities in Lebanese affairs run the gamut between blatant declarations by the Syrian ambassador in Beirut to covert manipulations and pressures on the political figures. Saudi Arabia and Qatar are also known to interfere, and the Taef or Doha accords come to mind as examples. There were many examples of external powers interfering in the country's affairs mentioned earlier in this thesis. It consistently gets in the way of the Lebanese taking care of their own internal affairs, and 
turns their attention away from focusing on their economic wellbeing and prosperity. With interferences come threats to the safety and stability and that can in turn be used as an excuse to do away with democratic practices. As mentioned earlier, when survival is the main concern, democracy falls by the wayside.

\section{The Internal Challenges}

The internal challenges will be discussed within the frame set by the theoretical model of this thesis. By definition a Consociational democracy is a "grand coalition" of powers as prescribed by the Constitution. Those powers quite often become at odds with each other. To avoid the tyranny of the majority, they are given "veto powers," and that sometimes leads to paralysis, rather than consensus. The "proportionality" in the administrative offices, meant to divide up equally the government positions, could cause inefficiency and incompetence in the bureaucracy. The "segmental autonomy" could easily backfire and lead to inequalities in the application of civil rights. We will continue to use the lenses of the attitudinal, constitutional and behavioral components to look at the issues of consolidation in this Consociational democracy. The three components are manifested in the five inseparable and interdependent arenas, as defined by Linz and Stepan. We will frame the challenges within these arenas: the rule of law, the political society, the civil society, the usable state and the economic society.

In the first arena, that of the rule of law, we will address the dictates of the constitution in a Consociational democracy. That would include looking at the 
challenges resulting from the "grand coalition" and the minority veto it entails, at the Taef Accord which brought some amendments to the Constitution and, with those amendments, more challenges. We will also look at the challenges ensuing from the segmental autonomy and the proportionality among all segments of society. We will then examine some aspects of the separation of powers as it is put in practice in Lebanon, and discuss the fact that there still is a need to affirm that Lebanon is considered the final homeland of its citizens. Finally, and as a result of all the events that took place in Lebanon and of the passing of time, it is imperative to look at the challenges caused by the changes in the demographics of the country.

In Lebanon, the division of power is not based on the majority in numbers; it is rather based on the equal division of power between the different religious rites. The reason behind that is the presence of the Christian community in Lebanon, which is regularly described as the reason behind the existence of the country as an independent state (Gemayel, Khalifeh, Pakradoni, Shiha and many others). To protect the Christians' presence and independence, they were given guaranteed positions in the government and in the grand coalition equally to the Muslims. The coalition also includes Hezbollah as part of the democratic regime, even though the party is philosophically opposed to abiding by laws other than the "Shari'a" (Islamic law as dictated by the Koran). The grand coalition is protected by the Constitution, but it is an artificial, forced system that can be easily undermined. That was illustrated by the paralysis caused to the political 
system and institutions when Hezbollah members withdrew from the government from late in 2006 until mid 2008.

The Taef Agreement took into consideration the fact that the demographics have changed since 1926 when the Constitution was first ratified. Even though the division of the major posts remained, the powers of each post were modified.

"The intention of this agreement was to eradicate the dominant position of the Maronites as it was ensured by the old formula and to allow for equitable participation of Christians and Muslims in the Cabinet. This parity may also be observed in the system of distribution of seats in Parliament and in Grade One posts, and their equivalents in public service Jobs. The post of President, traditionally assigned to a Maronite, provided him with power as the head of state and the symbol of its unity. The president was also considered as the custodian of the country's unity, independence, territorial integrity and constitution. The position of Prime Minister, a traditionally Sunni post, as the President of the Council of Ministers, was strengthened; similarly, the power of the ministers as members of the Council increased. The Prime Minister presides over the Council of Ministers; he is to be nominated by the President who conducts 
mandatory parliamentary consultations and shares the results with the Speaker of Parliament. In Parliament, the position of the Speaker, a traditionally Shia post, has gained importance because the Speaker's term of office was extended to four years. In addition, Parliament has been reinforced because the number and type of cases under which the executive authority can dissolve it were set out and were limited to three rare ones." (Krayem, 1994, in “The Lebanese Civil War and the Taif Agreement," downloaded from ddc.aub.edu.lb/projects/pspa/conflict-resolution.html)

The Taef agreement put into writing what was known as the National Pact. Even though the Taef agreement specifies that this political confessionalism is only temporary, it had the opposite effect by making the confessionalism part of the written constitution and more engrained than ever in the political system.

A Consociational democracy is by definition temporary. It is a transitional phase towards a democracy where the division of power is no longer based on the religious affiliation. Even though there are regular calls by many politicians, journalists, researchers, and leaders to move beyond the political confessionalism, it is proving to be quite difficult to eradicate from the political scene: 
"Since 1943, political confessionalism has been considered as temporary arrangement that should be expunged as soon as possible, but it has continued to predominate. In Lebanon, transforming the provisional decisions into permanent ones has become a tradition, reaffirmed most recently with the Taif Agreement. (--) Such a position contradicts the establishment of a strong political system that 'provides for legal and peaceful ways for its own amendment, for its adjustments to changes in society' (Salameh 1991, 57). The political reforms proposed by the Taif Agreement were marked by a strong contradiction evident in the gap between sectarian thought or philosophy and the democratic aspiration for a modern, secular, nonconfessional, and stable political system in Lebanon." (Krayem, 1994, in "The Lebanese Civil War and the Taif Agreement," downloaded from $d d c . a u b . e d u . l b / p r o j e c t s / p s p a / c o n f l i c t-$ resolution.html)

The Taef accord itself was a temporary arrangement in order to put an end to the fifteenyear war. It is still in effect today rather than being a stepping-stone away from a Consociational democracy. 
Behaviorally, and to go back to the Linz and Stepan's definition, it is true that no significant political group is seriously attempting to overthrow the regime or secede from the state. As for the attitudinal component, democracy is still considered as the only game in town, but a special democracy where the grand coalition allows for all members to participate in the ruling government. Constitutionally, the temporary arrangement is still followed, and conflicts are habitually resolved within the dictates of the procedures and institutions established in a mutually agreed upon process. It is however proving difficult to move away from the temporary to a permanent system. It would mean that the religion factor is taken out of the equation: it would be necessary to keep the grand coalition at the high levels of government to protect the minorities, and to guard the specificity of the make-up of the Lebanese society. Where it should and could start to take place is in the administrative offices and the official bureaucracy: the religious quotas should be replaced by sheer competence.

Another issue that the Taef agreement addressed, and which was also part of the 1926 Constitution, was the statement that Lebanon is "the final homeland for all its citizens." The tendencies of the Lebanese to seek support from outside powers are still firmly entrenched. Eliciting support from the outside in order to govern on the inside is still getting in the way of a transparent and stable democracy. There are regular reports in the media about visits by Lebanese politicians to Egypt, Syria, Iran, Saudi Arabia, and lately Turkey in order to solve local political issues. Visits by the ambassadors of the United States or France to the local leaders are also common occurrences, especially 
when a local crisis is threatening to shake the calm of the country and the region. This tendency still undermines the stability of the democracy in the country and the firm belief of the Lebanese citizens in the possibility of a stable and independent regime.

The Constitutional component in this portion of the rule of law arena, shows the conflicts sometimes being resolved outside of the established institutions by turning towards regional or outside influential players, whereas conflicts should be resolved within the dictates of the laws and the established institutions. The attitudinal surveys show the Lebanese firmly believing in Lebanon as their final homeland. As for the behavioral component, it seems to be suffering from the leaders of the segments turning constantly towards outside forces to interfere in the local affairs. The different meetings and visits are a regular occurrence on the evening news and in the print media.

The Grand Coalition in a Consociational democracy calls for consensus in matters of national importance, and the right to a veto given to each segment is inherent in the system. That leads to the tyranny of the minority and to a paralysis of the government. The veto card has been played more than once by the Hezbollah ministers and their allies in the government. Some of these instances include refusing to vote in the cabinet meetings or parliament meetings, refusing to call for a Parliament session, refusing to show up to the cabinet meetings, resigning en masse from the government (An-Nahar Nov.11, 2005), not showing up in parliament on the part of the opposition to elect a new president (An-Nahar Dec. 2006 and Jan. 2007), and insisting on having one third of the 
government ministers to guarantee veto power (An-Nahar Dec. 18, 2007). The Shiite ministers walked out of the government following the assassination of Prime Minister Hariri and the condemnation of Syria by the Council of Ministers. They especially aimed at protesting the creation of an international tribunal to look into Hariri's assassination (An-Nahar, Nov 12, 2005). By walking out they paralyzed the country for over a year. Below are more examples of the challenges inherent to the current system and which make it difficult to function under the cover of the existing institutions:

- The tent city in downtown Beirut close to the government offices erected in an effort to bring down Prime Minister Seniora's government. Seniora refused to resign as long as they had the Parliament's confidence (An-Nahar, Dec 4, 2006).

- Petition signed by 70 MPs to ask the Speaker to convene the Parliament to discuss the issues in the Parliament rather than on the streets and in the tent city that is ruining businesses downtown. (Jan 13, 2007)

- Paralysis of the parliament as a result of the Speaker's refusal to call it to convene. (Dec 23, 2006)

- Refusal of pro-Syrian President Lahoud to call for elections to replace the assassinated MP Pierre Gemayel in order to keep the scale tipped in favor of the opposition. Twenty-eight MPs sign a petition that accuses the President of infractions to the Constitution for not calling for elections in a timely manner. (Dec 28, 2006) 
The minority veto dictated by the Constitution of the land allowed for the minorities to manipulate the system in some cases while, in others, to paralyze it and to prevent the institutions from functioning. The constitutional component in this instance fell prey to the system itself, while the behavioral component showed members of the government going as far as paralyzing the government and the institutions in place, yet stopping short of overthrowing the democratic regime. The attitude of the citizens was split along the lines of the two coalitions facing each other, but the one thing they had in common was not resorting to an alternative to democracy.

In Lebanon, and under the dictates of the established Consociational democracy, in matters of education, marriages, religious practices, and all personal and religious matters, the different religious courts and leaders enjoy a large degree of power and of autonomy. The personal status in Lebanon is governed by the religious authorities and courts. That makes it quite difficult for a civil marriage or for an inter-faiths marriage to take place. Applying religious laws as a result of the segmental autonomy also creates inequality between men and women when it comes to inheritance, child custody, alimony, divorce and the right to citizenship given by the mother. It goes contrary to the democratic principal of equality before laws and equality of civil rights. There are repeated calls from different factions of society in Lebanon to introduce civil laws that replace those of the religious courts in personal matters. 
This same issue was addressed in the 2007 Springhints - Mind the Gap (Le printemps des interrogations) survey. Question 10 addressed the "contradictions" between some of the Lebanese laws and the Chart of Human Rights. It asked whether the laws discriminating against women should be modified: $90.6 \%$ of the university students and $95.4 \%$ of the Internet users said yes. Inter-faiths marriages are complicated because personal and civil matters are kept out of the government regulation and kept within the sphere of the religious courts and laws. That makes it very difficult for an inter-faiths couple to marry in Lebanon unless one of the two converts to the other's religion. When asked if the choice should be guaranteed and protected by the government, $84.5 \%$ of the university students and $87.4 \%$ of the Internet users answered affirmatively.

In order to protect the autonomy and specificity of each segment in the Lebanese society, the Constitution took out the government from the equation of personal issues and handed it to the religious authorities. That opened the door to inequalities that are contradictory to the dictates of the Constitution. Where religious laws are applied, the state took itself out of the picture: it is ironic that by definition the behavior component of the consolidated democracy states that no significant political group would attempt to overthrow the government or secede from the state: in this instance the state chose to stay away. As for the attitudinal component, the Lebanese are starting to move more towards the secularization of their civil or personal affairs, as shown in the Springhints survey mentioned above. 
Another aspect of the Consociational democracy, and in order to guarantee the equal sharing of the positions in the official administration, jobs are assigned according to religious affiliations. That practice is routinely leading to naming administrators and employees according to their religious rites, rather than their professional accomplishments. The aim is to satisfy a quota, instead of hiring competent employees. That inevitably leads to nepotism, inefficiency and corruption.

The biggest fear in this case, behaviorally, would be the fact that corruption and nepotism could lead the disgruntled citizens to seek alternatives, even if it meant getting rid of the current system in place. Attitudinally, one of the surveys mentioned in this study, showed an inclination to call for a military government, albeit temporarily, to get rid of the chaos and the disastrous sit-in in the commercial center of Beirut. That shows the impatience and almost disgust the citizens have towards the system that encourages corruption and incompetence. Other surveys also showed the readiness and anxiousness even of the citizens to do away with the quota system and to use competence and experience as the criteria for the administration and the bureaucracy. Constitutionally, the corruption and the nepotism are a result of a misuse of the laws in place, and of using the quota to swell the numbers of the partisans of the same religious rite, with a total disregard of their abilities and of the services they need to render to their fellow citizens.

In a democracy, the separation of powers makes up one of the pillars of the regime. In Lebanon, article 28 of the Constitution made it possible for an elected member 
of the Chamber of Deputies to be also a minister in the Government. That would complicate the separation of powers and the system of checks by the Legislative branch of the Executive Branch. It also complicates the voting by the Parliament members to grant confidence to the appointed government or to withhold it at a later point. It is very common in Lebanon to have an elected Deputy be named a Minister. The Government or Cabinet has to be given the vote of confidence by the Parliament for it to be official. The Cabinet members are also accountable before the Parliament and could be called for questioning in front of the Parliament. A Cabinet member who is at the same time an elected member of the Parliament might eventually find himself or herself in a position where he or she are questioned by another member of the Parliament, or having to face a vote of confidence by the Parliament of which he or she are members.

Another challenge to the system in place in Lebanon is the steep change in the demographics of the country. In the first census of the Lebanese citizens since the sixties, done by Youssef Shahid el-Douweihy, and published in An-Nahar on November 13, 2006 of the nearly five million Lebanese, the Christians made up $35.33 \%$ of the population, the Shiites $29.06 \%$, the Sunnis $29.05 \%$ and the Druze 5.38\%. The Christians were made up of 19.47\% Maronite Catholics, 6.85\% Orthodox, 4.55\% Roman Catholics, and $2.27 \%$ Armenian Orthodox. The Constitution was written on the basis of a Christian majority overall, with the Maronites making up the majority among Christians, and with the Sunnis making up the majority among the Muslim factions. These 
demographics have changed, with the Shiites demanding more powers and more representation.

Another side of this issue is the refusal of the Shiites to allow the expatriates to vote in the parliamentary and municipal elections for fear of tipping the scale towards the other side. This is resulting from the fact that most of the expatriates are Christians. The fact that 8.2 billion dollars, or $21 \%$ of the country's income, come from the money sent in by the expatriates (IMF figures quoted by Marwan Iskandar in his front page article of the daily An-Nahar, November 21, 2010) should make up a strong push towards giving the expatriates the right to participate in the decision making process in the country, namely being able to cast their votes in the parliamentary elections.

In this issue we see mostly a maneuvering to control the number of votes rather than to overthrow the democratic regime, or to solve conflicts from outside the established institutions. Quite a few laws were proposed according to the dictates of the Constitution, and the results were either voted down or stalled in commissions, which in itself shows a respect of the system in place. The three components of a consolidated democracy are satisfied to the extent that quite often they are falling prey to the political game, within the confines of the democratic rules, rather than to a skepticism or doubt in the democratic regime itself.

In the Political Arena, the Lebanese political life takes place in a traditional society and a closer look at the political parties in Lebanon would show them following 
family and religious lines rather than purely political lines (An-Nahar article /op piece by Rodrigue Krayem in the Aug 11, 2004 issue p. 13). The political parties in Lebanon are numerous and free to operate. Their number is around seventy-eight parties, at last count, grouped together in different coalitions. They are usually formed along religious lines, and they do have a predominantly Christian or predominantly Muslim constituency. The leaders of these parties are at the same time the traditional leaders of the societal segments. They are elected to the parliament and are part of the government, and therefore of the grand coalition. These "elites" participate in the political process through elections and other democratic institutions. An intriguing mix, then, of western qualifications and local factors play in the make-up of the political parties in Lebanon.

On the one hand, the presence of numerous political parties is an important sign of a democratic regime that allows for conflict and differences. On the other hand, the majority of the political parties in Lebanon are formed along religious affiliations and/ or allegiance to traditionally prominent families. The parties themselves are led mostly by well-known political families, and the party leader's post is handed down from father to son. They are also represented in the parliament and have their own electoral machines to get their candidates to the parliament, and they do suffer from the "complex of the founding leader" (el-Khazen, 2002. p. 84). The political parties seldom move towards a philosophy or a political platform and program that go beyond the personality and the popularity of the leader to attract followers. That poses one of the major challenges to the consolidation of democracy in the country: in a democratic regime, elections are 
usually used as a mean to ensure the accountability of the leaders, and if the citizens are dissatisfied with the performance of the elected officials, they will not reelect them. Not re-electing an official because of dissatisfaction is not the case in Lebanon: the same leaders get re-elected even though the citizens' satisfaction rate is very low. It is a reflection of the traditional society's norms where allegiance to the leader or the "Za'im" ${ }^{11}$ is deep rooted and makes it hard for the followers to act as citizens. The contract ties are still not as strong as those of the family or village or clan ties. (Fukuyama, 1996; Weber, 1946 ).

A new study published by Karam Karam on the role of political parties in Lebanon found that it is closely related to the political regime and the electoral system. That system is based on confessional representation, and aiming to have religious representation within the parliament. It ensures the distribution of seats according to religion, confession, and region that is pre-determined in the Constitution. (An-Nahar Nov. 12, 2008 p. 13). Once the population as a whole moves away from thinking along the lines of political confessionalism, it would then be possible for the system to move towards secularism. It would be very hard to get to the "laïcité" as it is applied in France. Religious affiliation will have to be taken out of the political arena to reach the laïcité. At this point in Lebanon it seems as if there will always be an influence of religion in everyday life and in the local traditions.

${ }^{11}$ Arabic term for leader, usually has the connotation of a clan leader. 
Looking at this arena through the lenses of the attitudinal, the constitutional, and the behavioral components, we see that, here too, the three components are present as they were described by Linz and Stepan. The changes, however, if changes were to take place, are falling prey to the fact that they are going against the tide of established traditions and engrained customs and beliefs. The respect to the za'im or to the leader is too deeply engrained in a traditional society such as the one in Lebanon for them to be replaced by contract ties. The same is true for the influence of religion and religious leaders in a democratic system.

Moving on to the Civil Arena, the numerous NGOs that operate in Lebanon, including the powerful syndicates or professional associations, act as an antidote to the disengaged individual and a manifestation of an active participation of the citizens in the social arena, and through it in the political process. The role the NGOs play in Lebanon does fit the description their role is given in the western literature, with the important distinction that they are operating in a traditional society that counts mostly on the family and the close relatives and acquaintances for assistance rather than on the government's aid. When the centralized government is not very efficient and results in rigidity in the delivery of services (O'Connell, 1999) (Salomon, 1999), the third sector acts to fill that void. The organizations in the third sector also play an advocacy role and push for change to satisfy what they perceive as a pressing need (Reid, 1999). Acting as advocates of the citizens against the government is seldom allowed in non-democratic countries. That is 
why the active presence of these advocacy groups is a strong indicator of a free and democratic society.

In Lebanon the NGOs play a role that is both supplemental and complementary to that of the government. The challenge to democracy comes in when these associations or organizations take the place of the government. They end up replacing the government when the official agencies are not there to provide basic services to all in an equal and non-discriminating manner.

This allegiance to the leader of the NGO or the political party that is a result of services rendered, could weaken the constitutional component of a consolidated democracy: resolving conflicts would then be done by resorting to the leader or his clan instead of "within the dictates of the law and through the institutions established in a mutually agreed upon process " (Linz \& Stepan 1996, p. 5). Attitudinally, political change might either not take place to keep the Za'im in power, or might happen outside of the "parameter of the democratic formulas" that calls for accountability through elections. Behaviorally, the actors are not trying to secede from the state, instead their allegiance is to the leader who is part of the ruling establishment.

In the fourth arena, that of the Usable State, we will find many challenges caused by the presence of an armed militia in the country in addition to the army. The bureaucracy in the country is not as transparent or as efficient as it should be, and the citizens' needs and access to basic services are not being met. In Lebanon, the enormous 
and insurmountable issue of the presence of armed groups on its territory, due to the Israeli-Palestinian conflict, deeply complicates matters. The arms and the use of force in the country are not a government monopoly, and that is a serious threat not only to the country's democracy, but also to its safety and stability. There are, however, large portions of the population that strongly believe in the fact that the official army should be the sole armed force in the country. One of the major challenges to the usable state in Lebanon is the presence of Hezbollah ${ }^{12}$.

The Party of God, an armed and powerful militia that exists in addition to the official army in the country, is a serious threat to the democratic regime. Hezbollah's armed and strong presence led to clashes between its members and the Sunni supporters of the Future political party and coalition led by the Prime Minister Saad el-Hariri. There were also confrontations between Hezbollah and the minister of communication, between Hezbollah and the army, the downing of an army helicopter causing the death of the pilot and wounding the co-pilot, and Hezbollah's causing a war with Israel that brought destruction, death and displacement to the whole country (July and August 2006, AnNahar). Those events were reported in An-Nahar on the following dates:

- June 2, 2006: demonstrations and destruction to property in a Christian neighborhood of Beirut following the mentioning of the name of Sheikh Hassan Nasrallah in a TV station's comedy show.

12 Which translates into the "Party of God", another manifestation of the deeply entrenched religious beliefs in politics. 
- July 13 through Aug 16 2006: Israeli attack on Lebanon caused by Hezbollah's kidnapping of two Israeli soldiers in South Lebanon.

- October 28, 2006: the political leaders of the majority flee the country after receiving threats for not supporting Hezbollah in its war.

- May 4, 2008: the discovery of surveillance cameras set in the airport by Hezbollah and of a separate communication system for the party. That led to a crisis between Hezbollah and the cabinet, especially the communication minister and the Prime minister.

- May 8, 2008: clashes between Hezbollah and Sunni supporters of the Prime Minister, attack on the Future newspaper and TV station (the mouth pieces of the leading Sunni political party whose leader is the Prime Minister), clashes extending to other regions causing dozens of deaths and a large number of wounded.

- August 29, 2008: Hezbollah shoots at and downs an army helicopter that was flying in what the party considers sensitive area in the South. The Lebanese Air Force pilot was killed and his co-pilot was wounded.

The presence of an armed militia in the country elicits different reactions from different factions of the population as shown in the surveys mentioned in this study. The attitudinal component of a consolidated democracy would be satisfied if the totality of those surveyed refused having armed militias in the country other than the national army. 
As for the constitutional and the behavioral components, they are undermined by the existence of the "armed resistance". The biggest challenge to these factors is the fact that the definition or the raison d'être of Hezbollah are not agreed upon by the Lebanese. It is seen by its supporters as an armed resistance, while the rest of the people see it as an armed militia that undermines the legitimacy of the government and threatens the stability of the regime. Another threat to the democracy in place in the country is Hezbollah's allegiance to a foreign regime rather than to the Lebanese government. It is supported financially and politically by the Iranian authorities and to some extent by the Syrian regime. The strong ties with the Iranian administration come from the obedience to the Shiite Ayatollahs in Tehran.

As for the efficient and transparent bureaucracy there is a lot to be desired, even though some progress is being made in this area. After three decades of war and chaos, corruption was and is still rampant in the administrative offices and the bureaucracy. Favoritism and catering to the whims of the za'im and the clan of the za'im makes it very hard for ordinary citizens to get the services to which they are entitled from the government. However, improvements are being made, and little by little quality and experience is replacing nepotism and bribery.

One thing to keep in mind is that the administrative posts are filled according to a quota that distributes the jobs among the different segments of the society. That system leaves the door open to corruption. On the other hand, administrative proportionality is 
one of the components that Lijphart cited as part of a Consociational democracy. The Lebanese are very aware of this fact and of the pressing need for reform. That is why two of the articles of the Taef Accord (May 11, 1989), which amended the Lebanese Constitution and put an end to the war that started in 1975, aimed at doing away with the political confessionalism (article 2G) and at working towards administrative decentralization (article 3A). These two articles however, have yet to be put in practice. This finds the constitutional component of the consolidation of democracy satisfied in theory since the Constitution and the Taef accord are calling for administrative reform. For the attitudinal factor, the surveys do show impatience with the current bureaucracy. The fact that it is still taking place however is the obstacle to overcome. Another challenge is the location of the country in a region that is overwhelmingly Muslim, and the Consociationnal democracy was the way to ensure the existence and safety of the Christians in the country and in the area in general. This point was addressed earlier in the challenges' section, but it bears repeating that the grand coalition that Lijphart described remains necessary on the highest level of the government to protect the identity and the special character of the country. The reform should come, and according to the dictates of the laws, at the bureaucracy level: when hiring the administrative employees, their competence and professional experience should be the deciding factors, not their religious rites.

Electricity, running water, building and maintaining roads, bridges and other infrastructure, health care and a social safety net, all are government services that are 
seriously lacking and are hit-and-miss in most areas beyond the capitol and the larger cities. This is where the private enterprise alongside the NGOs steps in to fill the void, and the NGOs are becoming more dependable and more efficient than the government. Even though the laws and the institutions are in place, the facts show that the citizens both in their behavior and in their attitude do not count on the government to provide them with services; they do expect it to, however.

The arena of the usable state presents the most challenges to the consolidation of democracy. It shows the state as weak, incompetent in providing basic services, taking the backstage often to za'im and his clan, and falling prey to corruption. All of these are factors that lead the citizens to find replacements that could fill their needs. The reputation that Hezbollah has for transparency and honesty could in a way explain the popularity the "Hezb" has among its followers, in addition to the fact that it is providing the needed services in its areas: hospitals, schools, paved roads, and financial assistance. It is a state within a state, and its leaders are not democratically elected. However, it is very important to note that Hezbollah is participating in the democratic system by having candidates run for parliamentary elections, and win. It also has several ministers in the cabinet, as representatives of a political party. We could say that what is considered, by definition, as a threat to the democratic regime, is participating in the democratic institutions, resolving conflicts most of the time through the established laws and institutions, and acting as if no other regime is acceptable. The Hezb could have easily thrown a coup d'état and taken over the ruling of the country, they definitely do have the 
needed arsenal. They did in a couple instances use their arms to force the issues and to attack their political opponents, as mentioned earlier. The incident caused a few deaths and the destruction of the television studios and the newspaper locales of an opposing political party. Their arms remain a threat to the regime, are feared by political rivals, and are provided by a foreign country.

The fifth arena, the Economic arena, in Lebanon is set in a market economy with the idea of a free market deeply entrenched in the Lebanese culture, tradition, and history dating back to the Phoenicians. It is affirmed in the article f. of the Preamble to the Constitution: "The economic system is the free market and ensures private initiative and the right to private property." The free market in Lebanon is one of the qualities that set the country apart from its neighboring Arab countries, where command economies and/or a rentier state under an authoritarian regime are the norm. The higher income in Lebanon as a result of the free market, the entrepreneurial spirit, strong in comparison with the surrounding countries, and the higher level of education ${ }^{13}$, contribute to a different attitude towards democracy and towards government.

With the post-modern values in the background, the situation in Lebanon stands out, compared to the Arab countries in the region. Lebanon differs in that it is a mixture of highly educated, fairly comfortable society, possessing a free market economy that relies on services, mostly tourism and banking; it is an open society with a high degree of

${ }^{13}$ Adult literacy rate at $98.4 \%$ for males and $86 \%$ for females in 2007 according to the World Research Institute's Earthtrends. 
freedom, a high degree of autonomy, of entrepreneurial spirit, and of respect for private property rights. When the worries of pure survival are surpassed, they are replaced by emphasis on economic independence, education, and political and civil freedoms. However, as a result of the repeated wars, the corruption in the government, the brain drain and other causes, the middle class in Lebanon is rapidly shrinking and it is being replaced by a low-income class. That could pose a real threat to the democratic values in the country. The proliferation of weapons among Hezbollah members, added to the culture of war replacing the culture of democracy and of "life" in the areas of high Shiite population steer the population away from the values associated with a free democracy. A culture of war does not provide a good atmosphere for tourism and is not inviting to visitors from outside the country, which seriously impacts the all too important tourism revenues. A number of services that used to be provided by the Lebanese in Lebanon are now based in the Gulf and namely in Dubai or Qatar. These include an international media center, universities, museums, hotels and commerce centers. The exodus of these services to safer countries is a result of the continuing conflicts in Lebanon or the threat of conflicts either between Hezbollah and Israel (July 2006) or Hezbollah and internal rivals (May 2008).

The importance of education that Inglehart and Wenzel emphasized in instilling democracy in a country, and the post-industrialized values they see in developed countries (Inglehart \& Wenzel, 2007), are falling prey to the survival issues faced by the Lebanese. The well-reputed education in Lebanon is becoming prohibitively expensive, 
whether it is at the minimum required level or at the university level. The quality of education in the government-run schools is going down with less emphasis given to world languages, and with poorly compensated faculty. The culture of war turns the citizens away from respecting the day-to-day laws and regulations put in place according to a democratic process, and replaces them with a different set of rules. All of these issues get in the way of a prosperous, well-educated and peaceful economic society. It is a society where the laws and regulations meant to protect the individual's property and to allow for prosperity are taken over by a violent chaos that makes it hard for the servicesbased economy to survive. During the times when Lebanon had a thriving economy and scored highly on the Freedom House or the Polity IV scales, the middle class was prosperous and made up the majority of the population. At present, the middle class numbers are shrinking for several reasons, mainly the brain drain and the immigration of those who can afford it, but also due to the dire economic circumstances brought upon the country by the war, by the corruption of those in government and by the constant threat of violence. That threat comes mainly from the presence of armed militias, the occupation by Israel of a couple villages in the South, and the constant interference by neighboring countries in the affairs of Lebanon. 


\section{Conclusion and Prospects}

Looking at the three components of a consolidated democracy as defined by Linz \& Stepan, we can say that attitudinally the Lebanese accept no regime other than democracy. Behaviorally and constitutionally we see that conflicts are not always resolved within the dictates of the laws of the land.

Attitudinally, democracy is consolidated when the majority holds the belief that no alternative to democracy is acceptable as a way of governing, "when, even in the face of severe political and economic crises, the overwhelming majority of the people believe that any further political change must emerge from within the parameter of democratic formulas" (Linz \& Stepan 1996: 5). In Lebanon, and as seen through the surveys mentioned in this study, the citizens' attitudes lean strongly towards democracy, and to them no other regime is acceptable.

Constitutionally democracy is consolidated when "conflicts are habitually resolved within the dictates of laws, procedures and institutions established in a mutually agreed upon process" (Linz \& Stepan, 1996: 6). The Lebanese value the freedoms offered and guaranteed by the Constitution and are used to acting and speaking freely. The way their conflicts are resolved, however is not always done according to the mutually agreed upon process. It is important to keep in mind that these components of a consolidated democracy are interdependent and interactive, and are difficult to separate. 
Both the constitutional and the behavioral components manifest themselves in ways that interfere with the consolidation of democracy.

Behaviorally the democratic regime is consolidated when no significant national, social, political, economic or institutional actor tries to achieve his or her objective through non-democratic or violent means. Behaviorally, democracy is the only game in town "when no significant political group seriously attempt to overthrow the democratic regime or secede from the state" (Linz \& Stepan 1996: 5). In Lebanon, and even though there were no attempts to overthrow the regime, there were frequent attempts by different factions to achieve their objectives through violent means.

The citizens' aspirations are not always satisfied and they are not always channeled through the existing democratic institutions: the perennial grievances continue about poor government services, corrupt politicians, the lack of transparency and of accountability among those who are elected or in the executive branch. The complaints are sometimes manifested in sit-ins and in armed conflicts, but oddly enough, the same politicians are re-elected. Behaviorally and according to the definition of Linz and Stepan, democracy in the country is not consolidated. In quite a few instances the citizens' behavior resulted of frustration and dissatisfaction with the government's performance and was rather violent. The behavior ignored the established institutions and mutually agreed upon processes to resort to sit-ins, clashes and armed confrontations. The sit-in for instance, in 2006-2008, or the clashes between Hezbollah and its political rivals 
in May of 2008, and, the biggest conflict among them, the war that lasted fifteen years, all are examples of dissatisfaction of the masses and a recourse to violence. Granted some of the violent events were mainly a result of external factors, but there were violent occurrences nonetheless.

The disconnect between the attitude of the citizens and their behavior and the way they resolved their conflicts is a little puzzling: on the one hand the citizens do not accept any regime other than democracy, and have a widespread respect and demand for freedoms, while on the other hand violent behavior and confrontations do take place often enough to affect the Freedom House and the Polity IV classifications. Some of the behavior would not be tolerated in authoritarian regimes: sit-ins, demonstrations and militias would be crushed. The freedoms in Lebanon that allowed for the demonstrations and the sit-ins, and which are offered and guaranteed by a democratic regime, these freedoms were mismanaged, or there was too much freedom that bordered on chaos. This reasoning is also that of the Standing Committee of National Dialogue in a report mentioned earlier in this study and published in the An-Nahar of July 25, 1975. That chaos and external interferences are what led to the armed conflicts that lasted from 1975 to 1990.14

\footnotetext{
14 The Standing Committee of National Dialogue published a report in An-Nahar newspaper on July 25, 1975, on the causes that led to the war in April of 1975 mentioned earlier in this thesis, some of their proposed steps to avoid a relapse are:
}

- "A call to all to use politics and not violence 
Another disconnect is between the definitions of democracy offered by Linz \& Stepan and by Dahl and other western authors to apply in western societies and the traditional society in Lebanon. The western definition of democracy has some limitations when applied in traditional societies. One critical distinction between the western societies and the Middle Eastern ones is the importance the latter attach to religion and to religious affiliations. The separation of state and religion has not made its way into the Middle Eastern societies yet. It is still very difficult to take religion and religiosity out of the civil and political arenas. In Lebanon, the entire system is based on religious affiliation. A local model of democracy needs to take into account the important role of religion in politics.

The unresolved challenges shown in this thesis are mainly a result of the major presence of religious affiliation in politics. Even the political parties, albeit numerous, are formed along religious lines. A case in point is the fact that Hezbollah is made up of a Shiite majority and so is the Amal movement. That leaves little room for the

- "A modernization of the political, economical, and social regimes along with the educational and cultural ones, a modernization that is democratic and national leading to the disappearance of confessionalism, to a secular government, and to the sharing among all citizens of the responsibilities, sacrifices, and rights. To the realization of social justice and to a global developmental planning that lead to the citizen's feeling of personal and social security and to steer him/her away from violence.

- "Deepening of the social and civil conscience among all citizens through the family, place of worship, school, syndicate, party, club, and media in a bottom-up and top-down approach.

- "Deepening of trust among different factions in deeds and not just in words, a trust that the Lebanese people is capable of self-governing and of improving the regime through democratic means, and through conviction not violence. 
independent thinking Shiites to express themselves without being considered traitors to the cause or to their confession.

One more important distinction is the blind faith the citizens have in their “za'im”. The traditional tribal leader or powerful family leader still is considered infallible and his decisions unquestionable, and it is more often than not a male leader. The unconditional trust placed in the za'im and the absolute compliance to his decisions change the role of the political parties in a way that would only work in traditional societies. The reverence the za'im commands and his place in society also need to be taken into account when we look at democracy in the Middle East. In a democratic regime, elections are a way of holding the elected officials accountable towards the citizens who voted for them. In a traditional society, elections do not work in that same way: most voters keep reelecting the same "za'im" out of reverence and fidelity, even when they are dissatisfied with the services the government is providing.

Another shortcoming when we apply the western model in a traditional society in the Middle East, is that it does not take into account the attitude of Muslims towards the idea of a Nation State. The Muslims, in general and the Islamists in particular, reject the notion of a secular Nation State in favor of the Islamic Nation ruled by Islamic law. To Muslins, there should be no boundaries between the state and the religion, and a good Muslim does not take part in elections nor does he place human choices and human regimes above the law of God. However they do not mind participating in the elections 
game (The Economist, Feb. 4, 2006). In Lebanon, where at least half of the population is Muslim, with the Shiites making up the larger portion, how can we reconcile that position with a democratic government in place and a diverse society that also includes more than a dozen other religious sects? The Lebanese answer to that is to have an all-inclusive government, a "grand coalition" even with the factions whose philosophy contradicts the principles of democracy. Allowing all existing political forces to participate in the political process, including those against democracy, creates an inclusive society. The media carries repeated declarations from Sunni and Shiite leaders calling for the importance of the diversity in the Lebanese society and for the undeniable necessity of living side by side in the same country with the Christian citizens. Also, and quite importantly, there is a large portion of Sunnis and other Muslims in Lebanon who are indeed secular and do believe in the separation of state and religion.

This thesis studied a model of a plural society, and in many components, a traditional one similar to many others in the region. Therefore, this model can be used to understand the other traditional societies in the area. In the Lebanese society, the thriving and active NGOs and the numerous political parties play a major role in the governance of the country. They help traditional societies turn away from fanaticism through education both in the schooling sense (Inglehart, 1997 and Inglehart \& Welzel, 2005) and in the political sense (Fukuyama, 1995 and Putnam, 1993 and Putnam, 2000) and by channeling mass participation into government as described in Eldersveld \& Walton (2000). However, it became clear after this study that the western definitions of political 
parties and the western description of their functions do not apply to the political parties in a traditional society based mostly on family ties. The parties are a product of the society they operate in (Sayah, 2001; Almond \& Verba, 1989), hence the different nature of the Lebanese parties. Even with their particular nature, they still provide a channel for mass participation and a way to educate the masses about the political issues. The Lebanese model could therefore be used as a template to spread democracy in other countries in the area, especially ones with segmental cleavages based on religion and ethnicity. In a region that is a constant scene for violent conflicts and is subjected to authoritarian regimes, the Lebanese model could be used as a solution and a prototype to be applied in other countries. Linz \& Stepan did not want to "imply that there is only one type of consolidated democracy. An exciting new area of research is precisely on the variety of the consolidated democracies" (Linz \& Stepan, 1996: 6). By looking at the Consociational democracy in Lebanon, this study aims to enhance the Linz \& Stepan model with an added component, that of the importance of religious affiliation in a traditional Middle Eastern society. That would imply acknowledging the role religious affiliation and family or clan affiliation play in the decision making process and in the governing process.

Arend Lijphart looked at the Consociational democracy in four western societies in 1977 and concluded that the regime in Lebanon was a successful democracy. Today, however, and after all the events and changes that have taken place in Lebanon and in the region in general, it will be of a great benefit to see if the democracy in Lebanon still is 
working and if the Consociational format is, after all, still successful, or at least useful. Lijphart followed up his 1977 book with another one published in 1999, Patterns of Democracy: Government Forms and Performance in Thirty-six Countries (Yale University Press) in which he did not mention the Consociational democracy in Lebanon. His criterion for including democracies in the 1999 book was that they had to be functioning democracies from 1977 to 1996. During that time in Lebanon, democracy and all stability were under the wrath of the war that lasted until 1990, and then came the Syrian occupation.

This thesis picks up from where Lijphart left off, especially after the Cedar Revolution which started in February of 2005 and brought the Syrian occupation to an end. It offers a measurement tool tailor-made to a society and a regime such as the ones in Lebanon. It will be a tool useful to measure democracy in the surrounding region, in societies similar to the Lebanese one. It also leads us to the conclusion that a special model of democracy works better in heterogeneous traditional societies. The majority of the works that studied democracy looked at it in a homogeneous western society. In Lebanon, the society is composed of many segments. It remains mostly traditional, with blood or family ties still the norm instead of the contract ties that prevail in western societies. Not too many works studied democracy in a traditional plural society. This study is attempting to fill that void.

There is no denial that religion is still a major part of the political system in Lebanon. Taking religion out of politics will eliminate the need for a Consociational 
democracy since this system of governance is based on confessional divisions of the society. In other similar political arrangements, like in Cyprus or in Belgium, Consociational democracy was determined according to the ethnic divide. By taking religious affiliations out of the political arena, the regime in Lebanon will then follow in the steps of Switzerland which moved past the Consociational democracy. In the meantime, and as long as the society in Lebanon is a traditional society, religion and family ties play an important role. Even though a large part of the new generation is asking for the elimination of political confessionalism, it is taking a long time to do so.

In conclusion and to answer the questions posed at the beginning of this thesis, it could be said that the Consociational democracy in Lebanon still faces quite a few challenges before it can be described as consolidated. The challenges are a result of external and internal factors. Also, the model used to measure the consolidation of democracy in Lebanon had some shortcomings because it did not address the specificities found in traditional societies, namely the blurring of limits between religion and politics to some segments of society, the political culture and the importance of family ties.

The model that would apply to a society like the one in Lebanon should include the following components:

Consolidated democracy $=$ behavior + attitude + constitution + religiosity and tradition in an autonomous state. 
For democracy to be consolidated in Lebanon certain things have to be changed. The political confessionalism has to be phased out, that will prove to be a tough issue especially that the regime is based on a "grand coalition" to protect the rights of the religious minorities in the country. By definition the "Consociational democracy " is based on a grand coalition between the different segments of society. In Lebanon the segments are based on the religious affiliation to protect the different religious confessions. Also by definition a Consociational democracy is meant to be a temporary or a transitional regime leading to a western style democracy. That takes us back to the previous point proved in this thesis and it is that the western style model of a consolidated democracy did not work in Lebanon. It did not work in most of the other countries that Lijphart looked at either, with the exception of Switzerland.

It is time then to rethink the relevance of the Lebanese political system. The present system that allows for the division of the top three political posts among the major religious confessions should be enhanced by a de-centralization of the government services and bureaus. Giving the different counties and towns autonomy to manage their own affairs and budget under the locally elected mayors and boards will lead to more efficiency and accountability. It will also satisfy the constant calls by the younger generation surveyed in "Springhints" to move away from the political confessionalism and focus more on competency. 
That model could also apply to the other traditional societies in the region that are currently undergoing a lot of changes. A democratic regime that is a product of a local traditional society could very well be the alternative to an authoritarian regime with a single official religion. 


\section{References}

Abootalebi, Ali R. (1998, September). Civil Society, Democracy, and the Middle East. MERIA_2(3).

Al-Asir, Mustafa. (1999, December). Legislative and Administrative Conditions in the Non-Governmental Sector in Lebanon. Paper presented at the Ministry of Social Affairs first annual Symposium on Volunteerism, sponsored by the UNESCO, Beirut, Lebanon.

Almond, Gabriel and Sidney, Verba. (Eds.). (1989) Civic Culture Revisited. Newbury Park, London, New Delhi: Sage Publications.

Altheide, David L. (1996). Qualitative Media Analysis. Thousand Oaks, London, New Delhi: Sage Publications. 
Atallah, Tony George. (2001, October). Democracy Report in Lebanon. Paper presented at a Symposium sponsored by the Joseph and Laure Moghaizel Foundation for Democracy and Human Rights, Beirut, Lebanon.

Awit, Michel. (1989). Les Maronites : Qui Sont-Ils? Que Veulent-Ils ? [The Maronites : Who Are They? What Do They Want?] Bkerkeh, Lebanon.

Baladi, André and Sarkis, Reina. (2007). Le Printemps des Interrogations [Springhints Mind the Gap] Beirut, Lebanon: Chemaly \& Chemaly.

Baroud, Ziad (2003, July 30). Interview. L'Orient-Le Jour, p. A1.

Ben Néfissa, Sarah. (2000, March 29-31). ONG, Gouvernance et Développement dans le Monde Arabe" [NGOs, Governance and Development in the Arab World]. A draft discussion paper presented during the UNESCO conference on NGOs and governance in the Arab Countries, Cairo, Egypt. 
Chalhoub, Elias. (2006). Promoting the Rule of Law and Integrity in the Arab World Project: Report on the State of Judiciary in Lebanon. $2^{\text {nd }}$ draft. A study done for the the Arab Center for the Development of the Rule of Law and Integrity, Beirut, Lebanon.

Corm, Georges. (2002). Orient-Occident, La Fracture Imaginaire [Orient-Occident, the Imaginary Fracture]. Paris: La Découverte.

Crabtree, Benjamin and Miller, William. Eds. (1999). Doing Qualitative Research. 2nd ed. Thousand Oaks: Sage Publications.

Dagher, Carole. (2002). Bring Down the Walls: Lebanon's Post War Challenge. New York: Palgrave Macmillan.

Dahl, Robert A. (1998). On Democracy. New Haven and London: Yale University Press. 
Daou, Father Boutros. (1977). تاريخ الموارنة الديني والسياسي

[The Political and Religious History of the Maronites]. Jounieh, Lebanon: The Paulist Press.

Djeredjian, Edward P. (2008). Danger and Opportunity: An American Ambassador's Journey Through the Middle East. New York: Threshold Editions.

El-Ahdab, Abdel-Hamid. (2003, August 12). Tribune - Avant même la chute de l'empire ottoman, beaucoup de Libanais avaient préconisé un nationalisme laïque: De la renaissance arabe à la décadence, y a-t-il un remède ? [Tribune - Even Before the Fall of the Ottoman Empire, Many Lebanese Called for a Secular Nationalism : From the Arab Renaissance to Decadence, Is There a Remedy ?] L'Orient-Le Jour, p. A1.

Eldersveld, Samuel J. (1989). Political Elites in Modern Societies: Empirical Research and Democratic Theory. Ann Arbor: The University of Michigan Press. 
Eldersveld, Samuel J. and Walton, Hanes Jr. (2000). Political Parties in American Society

$2^{\text {nd }}$ ed. Boston, New York: Bedford : St. Martin's Press.

El-Kha'i, Abdo. . (2001, October). Volunteerism: Motivation and Obstacles. Paper presented at the Ministry of Social Affairs Symposium on Volunteerism, sponsored by the UNESCO, Beirut, Lebanon.

Finer, S.E., Bogdanor, Vernon and Rudden, Bernard. (1995 reprinted 2006). Comparing Constitutions. Oxford: Clarendon Press.

Fukuyama, Francis. (1995). Trust: The Social Virtues and the Creation of Prosperity. New York: The Free Press.

Fukuyama, F. (1996, January). Trust: social capital and the global economy. International Social Science Journal: 379, 12-27 
Haddad, Bishop Grégoire. (2001, October). The Concept of Volunteerism and Volunteering. Paper presented at the Ministry of Social Affairs Symposium on Volunteerism, sponsored by the UNESCO, Beirut, Lebanon.

Hanna, Elias. (2008, May 10). Nharkoun Sa’id [Television broadcast]. Beirut, Lebanon: LBC

Huntington, Samuel. (1968). Political Order in Changing Societies. New Haven: Yale University Press.

Huntington, Samuel. (1991). The Third Wave: Democratization in the Late Twentieth Century . University of Oklahoma Press.

Ibrahim, Saad Eddin. (2003, October). Reviving Middle Eastern Liberalism. Journal of Democracy. 14(4). 
Inglehart, Ronald. (1997). Modernization and Postmodernization: Cultural, Economic, and Political Change in 43 Societies. Princeton University Press.

Inglehart, Ronald and Welzel, Christian. (2005). Modernization, Cultural Change, and Democracy: The Human Development Sequence. Cambridge University Press.

Joseph, Souad. (1994). Teaching Critical Thinking: An Elementary School Experience. In Messarra, Antoine (Ed). Building Democracy in Lebanon. Beirut: Publications of the Lebanese Foundation for Permanent Civil Peace.

Kahddouh, Mohammed. (2001, October). Why the Symposium on Volunteerism: A Social and National Cause. Paper presented at the Ministry of Social Affairs Symposium on Volunteerism, sponsored by the UNESCO, Beirut, Lebanon.

Karam, Karam (2008, Nov. 12) الأحزاب في لبنان [Political Parties in Lebanon]. An-Nahar, p. A13. 
Kan'an, Nehmat. (2001, October). The Concept of Volunteerism and the Relation Between the Private and the Public Sectors. Paper presented by the General Director of the Ministry of Social Affairs at the Ministry's Symposium on Volunteerism, sponsored by the UNESCO, Beirut, Lebanon.

Kemmis, Daniel. (1990). Community and the Politics of Place. Norman: University of Oklahoma Press.

Khalaf, Melhem. (2008, May 14) Open Doors program. Beirut, Lebanon: NOURSAT TV

Khalifé, Gilbert. (2005, April 14). Etude D'Israèl à la Syrie, en passant par l'Egypte de Nasser et l'OLP de Yasser Arafat, des fragments d'une longue histoire sanglante : La guerre au Liban, un véritable travail de sape entrepris par les puissances régionales . [ A Study from Israel to Syria, Going Through Nasser's Egypt and Yasser Arafat's PLO, the Fragments of a Long Bloody History: The War in Lebanon, a True Work of Sapping Undertaken by the Regional Powers ]. L'Orient-Le Jour. 
Khalifeh, Issam. (1994). In the Defense of the Unions' Freedoms. In Messarra, Antoine (Ed.) Building Democracy in Lebanon. Beirut: Publications of the Lebanese Foundation for Permanent Civil Peace.

Krayem, Hassan. (1994). The Lebanese Civil War and the Taif Agreement. Retrieved from The Digital Documentation Center at the American University of Beirut. ddc.aub.edu.lb/projects/pspa/conflict-resolution.html

LaPalombara, Joseph and Weiner, Myron (Eds.). (1966). Political Parties and Political Development. Princeton University Press.

Laurent, Annie. (2006, April). Le Liban: une vocation spirituelle. [Lebanon: a Spiritual Vocation]. Se Comprendre. Number 06/04.

Lijphart, Arend. (1977). Democracy in Plural Societies: A Comparative Exploration. New Haven and London: Yale University Press. 
Linz, Juan and Stepan, Alfred. (1996). Problems of Democratic Transition and Consolidation: Southern Europe, South America, and Post-Communist Europe. Baltimore and London: The Johns Hopkins University Press.

Malik, Habib C. (1998, March). Is There Still a Lebanon. MERIA. 2(1).

Messarra, Antoine (Ed.). (1994). La construction Démocratique au Liban. [Building Democracy in Lebanon]. Beirut: Publications of the Lebanese Foundation for Permanent Civil Peace.

Mhannah, Kamel. (2001,October). The Journey of Voluntary Work in Lebanon. Paper presented at the Ministry of Social Affairs Symposium on Volunteerism, sponsored by the UNESCO, Beirut, Lebanon. 
Moghaizel-Nasr, Nada. (1994). L'articulation entre éducation et construction démocratique. [The Articulation Between Education and Democratic Construction]. In Messarra, Antoine (Ed.), Building Democracy in Lebanon, Beirut: Publications of the Lebanese Foundation for Permanent Civil Peace.

O'Connell, Brian. (1999). Civil Society: The Underpinning of American Democracy. Hanover and London: University Press of New England.

Pakradoni, Kareem. (2007, Dec.22). N'harkoun Sa'id. [Television Program], Beirut: Lebanese Broadcasting Corporation.

Putnam, Robert. (1976). The Comparative Study of Political Elites. Upper Saddle River, N.J.: Prentice Hall.

Putnam, Robert. (1993, Spring). The Prosperous Community: Social Capital and Public Life. The American Prospect. 13(2). 
Putnam Robert D. (1995, December). Tuning In, Tuning Out: The Strange Disappearance of Social Capital in America. Political Science and Politics, 28, 664-683.

Putnam, Robert. (2000). Bowling Alone: The Collapse and Revival of American Community. New York: Touchstone.

Quilty, Jim. (2005, Sep.17). What makes people more democratic, anyway? Beirut: Daily Star p. A1.

Reid, Elizabeth J. (1999). Nonprofit Advocacy and Political Participation. In Boris, Elizabeth T. \& Steuerle, C. Eugene (Eds.). Nonprofits and Government: Collaboration and Conflict (pp.291-325). Washington D.C.: Urban Institute Press. 
Rivlin, Paul. (1997, September). Leadership and the Economy in the Arab World, 19501996. MERIA, 1(3).

Sakr, Etienne. (2005, December). The Politics and the Liberation of Lebanon. MERIA, 9(4). Article 6.

Saleh, Ali Salman and Harvie, Charles. (2005, January). An Analysis of Public Sector Deficits and Debt in Lebanon: 1970-2000. MERIA, 9(4).

Salomon, Lester M. (1999). America's Nonprofit Sector: A Primer. $2^{\text {nd }}$ Edition. New York: The Foundation Center.

Samii, Abbas William. (2006, Summer). Shiites in Lebanon: The Key to Democracy. Middle East Policy. 
Sayah, Ghassan (2001, October). Volunteerism and Society: Areas and Types of Volunteer Work. Paper presented at the Ministry of Social Affairs Symposium on Volunteerism, sponsored by the UNESCO, Beirut.

Selznick, Philip. (1992). The Moral Common Wealth: Social Theory and the Promise of Community. Berkeley: University of California Press.

Souhaid, Fares. (2008, July 8). Chidiac, May (Producer, Presenter). Bikoul Jour'ah, Beirut. LBC

The Economist. (2006, February 4)

Trochim, William M.K. ( 2006) The Research Method Knowledge Base On-Line at www.socialresearchmethods.net/kb/unobtrus.php

Tueni, Ghassan. (2008, January 31). خيار سليمان لم يسقط- لكن السوريين يخشونه 
[The Suleiman Choice Did Not Fall --- But The Syrians Fear It] An-Nahar, p.A1

Weber, Max (1946). Bureaucracy. Reprinted from Hans Gerth and C. Wright Mills, (Trans. and Eds.) from Max Weber: Essays in Sociology, Oxford: Oxford Press.

Weber, Robert Philip. (1990). Basic Content Analysis. Second Edition. Newbury Park, CA: Sage Publications.

World Research Institute. (2009, March 6). Earthtrends. Population, Health and Human Well-being: Country Profile- Lebanon. Retrieved from http://earthtrends.wri.org/text/population-health/country-profile-104.html

Wuthnow, Robert. (1999). Clash of Values: The State, Religion and the Arts. In Boris, Elizabeth T. \& Steuerle, C. Eugene (Eds.), Nonprofits and Government: Collaboration and Conflict (pp.267-290). Washington D.C.: Urban Institute Press. 
Yesilada, Birol, (Ed.). (1999) Comparative Political Parties and Party Elites: Essays in Honor of Samuel J. Eldersveld. Ann Arbor: The University of Michigan Press.

Yesilada, Birol. (2002). Realignment and Party Adaptations: The Case of the Refah and Fazilet Parties. In Sabri Sayari \& Yilmaz Esmer (Eds.), Politics, Parties, and Elections in Turkey. Boulder: Lynne Rienner Publishers.

Yom, Sean L. (2005,December). Civil Society and Democratization in the Arab World. MERIA_9 (4). Article 2. 


\section{References for the Surveys}

An-Nahar survey. (2006, August 9). In cooperation with the YMCA, the International Association for Administration and Training, and the Colloquium for Parliamentary Dialogue.

An-Nahar Annex Nahar el-Shabab.

El-Khazen, Farid. (2002). Political Parties in Lebanon: the Limits to Democracy in the Party Experience. Beirut: Lebanese Center for Policy Studies.

Information International. (2005, May 12 and May 13). Parliamentary Elections of 2000. A study commissioned and financed by the United Nations Interregional Crime and Justice Research Institute. An-Nahar. Tahkik section.

Information International. (2007, February/March). Opinion Poll: The Lebanese Follow Their Leaders, Prefer Peace but are Ready to Fight for Their Families, Country, and Religion. iMonthly, issue 56 . Beirut.

Information International. (2007, June/July ). Opinion Poll: The Lebanese Less Supportive of the Ongoing Sit-in: Divided over the Presidential Elections and with the Tribunal but with Conditions. iMonthly, issue 60 . Beirut. 
Information International. (2003, April 13). Survey: The Lebanese War Anniversary. An-Nahar (2003, April 22) p.A2.

Information International. (1997, October). Survey conducted in Lebanon. Available from: Information International, Azarieh building, Block 2A, first floor, Riad El-Solh Square, Beirut, Lebanon. Tel: 961-1-983-008.

Information International. (2000, September 23 - October 5). Opinion poll: PostParliamentary Election: Between Theory and Practice. Beirut.

Information International . (2000, December). A survey: Freedom of Expression in Lebanon. Beirut.

Information International. (2001, September ) . Opinion Poll : Government Performance After 300 Days. Beirut.

Information International. (2003, September). A survey: The New Reform Policy. Beirut. 
Information International. (2004, August ). Polling Lebanese Electorate. iMonthly, issue 26, Beirut.

Information International. (2004, December). Opinion Poll: The Extension of President Lahoud Term, the New Government and Resolution 1559. iMonthly. Issue 30, pp: 8-11. Beirut.

Information International. (2005, May). Opinion Poll : The Lebanese: $84.7 \%$ for the Election in May 7, 74.1\% with the Syrian Withdrawal. iMonthly, issue 35, pp:5-6 . Beirut.

Information International. (2006, October). Opinion Poll: Lebanese Divided Behind Their Leaders Over Critical Matters. iMonthly, issue 52. pp: 4-9. Beirut.

Information International. (2007, December). Opinion Poll: The Majority of Lebanese Support Holding a Referendum on Lebanon's Identity. 62.6\% Favor a Temporary Military Takeover. iMonthly, issue 65, pp.2-8. Beirut.

Information International. (2008, July). The Lebanese Polled. iMonthly, issue 72, pp: 4- 
10. Beirut.

Information International. (2008, August ). A survey: Foreign Countries: Friends, Allies or Enemies? The Answer Depends on the Confession and Loyalty to the Za'im. iMonthly issue 74, pp: 12 -15. Beirut.

IRI, LOAC, and Statistics Lebanon. (2006, June 14 - July 10). Public Opinion Poll on The Lebanese Political Environment.

IRI, LOAC, and Statistics Lebanon. (2006, November 15 - December 11). Perceptions of Politics, Leadership, and Current Events in Lebanon.

IRI, LOAC, and Statistics Lebanon. (2007, May 14 - June 11). Perceptions of Politics, Leadership, and Current Events in Lebanon.

Ismael, Issam. (2004, October ) . Political Parties' Missions. The Beirut Center for Research and Information. Studies retrieved on July 25, 2009 from the center's website at www.beirutcenter.info/default.asp?ContentID=588\&menuID=68.

Khoury, Roula. (2007, July 27) : A report: 
[Opinion Polls Show Lebanese’ Primary Allegiance to Leaders Not to Programs]. An-Near, p. 13, Beirut.

The Lebanese Center for Policy Studies. (2004, February). Governance Knowledge Sharing Program: Progress Report. Beirut.

Messarra Antoine, Ed. (2000) Marsad al-Democratiyah Fi Loubnan [The Democracy Watch in Lebanon]. Beirut.

Wike, Richard and Menasce-Horowitz, Juliana. (2006, July 26). Lebanon's Muslims: Relatively Secular and Pro-Christians but Support for Terrorism and Anti-Semitism are Widespread. Pew Global Attitudes Project retrieved from :

http://pewresearch.org/pubs/41/lebanons-muslims-relatively-secular-and-pro-christian

Statistics Lebanon Ltd. (2006, 11-13 Feb, 18-22 March, 19-24 of April, August 28 to September $1^{\text {st }}$, October 28 to November $1^{\text {st }}$, and December 29, 2006 to January 2, 2007). P.O.Box 55321 Sin-El-Fil, Beirut, Lebanon.

Statistics Lebanon Ltd. In cooperation with The University of Jordan. (2007, November). 
ARAB BAROMETER SURVEY PROJECT: LEBANON REPORT. Available at www.arabbarometer.org/reports/countryreports/Lebanonreport.pdf

The Fourth National Convention on Democracy and Youths Participation in Public Life. ( 2003, December 12-13-14) . Results published by the Center of Eastern Studies and Research. Antelias, Lebanon. Jeunes@ moncero.org and www.moncero.org

The Lebanese Center for Policy Studies (LCPS). (2004, February) in cooperation with the World Bank. The Governance Knowledge Sharing Program (GKSP) and the Regional Initiative on Governance in the Middle East and North Africa, Beirut.

Zoghby International. (2005, November). Six Arab Nations Survey Report. Submitted to the World Economic Forum's Arab Business Council.

Zoghby International. (2005,November 10). Unprecedented Middle East poll tackles key questions about future of Arab world. United Arab Emirates. Retrieved from: $\underline{w w w . a m e i n f o . c o m}$ 


\section{Appendix A}

\section{List of Political Demonstrations in Lebanon}

Appendix A is found in a Supplemental file: Spreadsheets showing lists, dates and numbers of arrests or injuries resulting from the political demonstrations from 1970 through 2009. There are three spreadsheets divided up according to major events in the country.

The first spreadsheet lists the events from 1970 to 1975, the year when the war started in the country. The second spreadsheet picks up again in 1990, when the fifteen-year war came to an end as a result of the Taef accord. The second spreadsheet continues until Dec of 2005. In 2005, and triggered by the assassination of the Lebanese Prime Minister Rafik Hariri, the Cedar Revolution put an end to the Syrian occupation of the country and started a new chapter in the country's political life. The third spreadsheet lists the political demonstrations from 2006 through 2009.

The spreadsheets are:

Dems 1975.csv

Dems thru 2005.csv

Dems thru june 09.csv 


\section{Appendix B}

\section{The Surveys}

\section{The Attitudinal Factor in Determining the Consolidation of Democracy}

Attitudinally, the democracy is consolidated when the majority holds the belief that no alternative to democracy is acceptable as a way of governing, "when, even in the face of severe political and economic crises, the overwhelming majority of the people believe that any further political change must emerge from within the parameter of democratic formulas." (Linz \& Stepan, 1996 : 5)

The following surveys go back to 1995 , the earliest available on the topic at hand. They include studies that were done in the years of the Syrian occupation that lasted from 1990 to February of 2005 following the assassination of Prime Minister Rafik Hariri and the resulting Cedar Revolution. The surveys done in that time period were done under an oppressive authoritarian regime. It is remarkable that the answers were frank and actually criticizing the regime and the system in place. It is also expected for the responses to show a perception of lack of democracy and dissatisfaction with the way the government is run. The Syrian authoritarian regime was in total control of Lebanon's political machine and at the helm of the Lebanese government. The people's attitude towards government under the Syrian occupation was the result of a restrictive regime and its controlling the mechanics of the government in place. The surveys used in this dissertation were either made public by the organization that conducted the study in line 
with their mission to educate the citizens, or they were made available at the organization's offices. To study the people's attitude towards democracy a multitude of questions were asked, and each survey used questions that studied one or more of the different components of a democratic regime. These ranged from the freedoms guaranteed by a democracy to the accountability of those in government and the role of political parties. The surveys will be listed in a chronological order rather than by topic mainly because of the major events that took place in Lebanon in that period and how they affected the Lebanese citizens' attitude towards democracy.

\section{The Surveys: a Chronological list}

\section{5: Lebanese Institution for the Permanent Civil Peace: Political parties.}

A survey mentioned in Farid El-Khazen's study on the Lebanese Political Parties for the Lebanese Center for Policy Studies: the survey was done in 1995 to study the commitment of the Lebanese adult citizens to the political parties and associations, only $10 \%$ of those living in the larger cities said they were committed to a political party, with $62 \%$ of the respondents refusing to be connected with political parties. As for the capacity of the political parties to offer effective solutions to the problems facing society, $69 \%$ of the respondents saw that political parties complicate matters rather than help with solutions. $51 \%$ expressed their doubt as to the capacity of the political parties to enhance the democracy and unity in modern societies. (Study by Abdo Ka'I in Parties and Political Forces in Lebanon. Antoine Messara editor. Published by the Lebanese 
Institution for the Permanent Civil Peace. 1996 (in el-Khazen, 2002: 61) It is important to note that this survey is dated 1995 as the country was coming out of the ravages of the war between the armed militias of, among others, the different political parties. The citizens have not yet recovered from the atrocities of the war and as a result are now under the occupation of the Syrian regime. All factors that lead to an unfavorable view of the political parties.

\section{October 1997: Information International: Political life, Performance of the}

\section{Government and of the Politicians.}

A Study done and published by Information International in three parts: Political Life in Lebanon, Performance of the government and of politicians, and The Three Presidencies and the Deputies of the Five Mohafazats.

The samples were taken randomly from the major cities in all five mohafazats (counties) of the country, with a larger number taken in Beirut because of the higher population density. The religion distribution was taken into account by doing the survey in different neighborhoods and suburbs according to the religious majorities living in a neighborhood. The percentages of the respondents ended up being as follows: $31.3 \%$ Sunni, 26.8\% Maronite, 15.4\% Shiite, 12.9\% Greek Orthodox, 6\% Druze, 2.8\% Roman Catholic, $2.5 \%$ Protestant, and 2.2\% Alaouite. As for the gender distribution it was $60 \%$ male and $40 \%$ female. Age distribution was for the under 40 years old group, those aged between 40 and 60 years, and those over 60 years of age. The survey was conducted in 
October of 1997.

The first question asked if there was a democratic political life in Lebanon: over half $(57.9 \%)$ of the respondents answered negatively, while $42.1 \%$ of them saw that Lebanon is a democratic state. Of the $57.9 \%, 33.9 \%$ saw that government is controlled by a mafia of rulers, while $25.1 \%$ saw that it is because they lack the freedom to express their opinion, while $21.4 \%$ saw that it is a result of foreign interferences, and $11.1 \%$ saw that those in power do not listen to the people. $5.3 \%$ of these respondents did not know the cause of the lack of democracy, and $3.2 \%$ saw that it is a result of confessionnalism.

Asked whether there is true opposition in the Lebanese political system, $45.7 \%$ saw that political opposition does exist while $53.5 \%$ saw that there is no opposition in the true sense of the word, that it is simply a superficial opposition and mostly for the appearances or to satisfy personal aspirations. There was no significant difference among the respondents to this question as a result of gender: males and females were roughly equally divided in their responses.

Religious factor: There were considerable differences along the religious lines in the response to the question about whether or not there is a democratic political life in Lebanon: $60.5 \%$ of the Christians saw that there is no democracy in the country in Oct of 1997 while $39.5 \%$ saw that there was. Among the Muslims 55.8\% saw there is no democracy and $44.2 \%$ saw that the political life in the country is democratic.

As for the existence of a true opposition $44.3 \%$ of the Christians saw that there is no true opposition, while $54.7 \%$ saw that there is a political opposition group. Among the 
Muslims $61 \%$ saw that there is no political opposition group, and $38.2 \%$ answered yes to the existence of a political opposition group.

It is important to note that among the religious groups surveyed there were large discrepancies between their answers along religious lines: $88.5 \%$ of the Roman Catholics respondents, $74.6 \%$ of the Shiites, $67.6 \%$ of the Maronites, $49.7 \%$ of the Sunnis, $47.1 \%$ of the Greek Orthodox, $45 \%$ of the Alaouites, $43.6 \%$ of the Druze, and $21.7 \%$ of the Protestants saw that there is no democratic political life in Lebanon.

As for the existence of a true opposition group, the highest percentage of those who do not see it come from among the Druze respondents $(67.3 \%)$, followed by the Sunnis $64.8 \%$ and then the Shiites $52.1 \%$, 50\% of the Roman Catholics and the Alaouites respondents, and then $47.8 \%$ of the Protestants and $44.5 \%$ of the Orthodox. The Maronites had the lowest percentage: $43.3 \%$ of Maronites are not finding a true and efficient political opposition group. Regional factor: There were marked differences also along regional lines, with those living in Beirut (74.7\%) and the Mount Lebanon (75.1\%) areas having the highest percentage of those who do not see the political life as democratic enough, with the lowest percentage $(32.2 \%)$ in the Bekaa valley region.

As for the regional distribution of the responses to the existence of a true political opposition, the highest percentage of respondents denying the existence of a political opposition came from the South (72\%), where both the Prime minister and the Speaker of the parliament are from. Beirut was next with (55.2\%) and Mount Lebanon (50.7\%) 
followed by the North (49.4\%) and the Bekaa valley (36.8\%).

Age factor: $50.9 \%$ of the respondents over 60 years of age saw the existence of a true political opposition, while $48.6 \%$ of those aged between 40 and 60 years saw that there is opposition, and $34.7 \%$ of the respondents under 40 years of age.

Income factor: Distributed by income the respondents were divided as follows:

$77,8 \%$ of those earning $\$ 1000$ or more per month, and $66.5 \%$ of those earning between $\$ 500$ and $\$ 1000$ a month, with $52.8 \%$ of those earning between $\$ 500$ and $\$ 300$ a month, and $50.4 \%$ of those earning less that $\$ 300$ believed that there is no democratic political life in Lebanon.

To the question whether there is a true political opposition $50 \%$ of those earning less than $\$ 300$ a month saw that there is political opposition, and $48.1 \%$ of those earning more than $\$ 1000$ a month agreed, followed by $44.8 \%$ of those earning a monthly income between $\$ 300$ and $\$ 500$, and $43.6 \%$ of those earning between $\$ 500$ and $\$ 1000$ a month. It should be noted that the official minimum monthly wage is a little under $\$ 300$.

Education factor: the higher the education level the less likely the respondents were to find the political life as democratic: $70 \%$ of those carrying technical or professional diplomas saw that there is no democratic political life in the country, with $64.1 \%$ of high school graduates, $62.5 \%$ of those in higher studies, $61 \%$ of university researchers, $59.7 \%$ of complementary level students (Junior high), and $47.4 \%$ of those with an elementary education. There was no marked difference in the responses according to education to the question that dealt with the existence of a true political opposition, with still the 
highest percentage of those denying the existence of a political opposition coming from those with the higher education.

The second section of the study asked about specific politicians, and that is not relevant to our purpose here.

Of the third section of the survey the most relevant question asked about the attitude of the respondents towards renewing the mandate of the president (which is not conform to the Constitutional dictates): over half of the respondents $(56.8 \%)$ refused the renewal of the President's mandate.

\section{February through September 1998, published In 2000: "Marsad Al-}

\section{Democratiyah Fi Loubnan” (The Democracy Watch In Lebanon):Importance Of}

\section{Liberties In Lebanon, Of Political And Civil Rights.}

This study was published at the end of nine symposiums run by the Joseph and Laure Moghaizel Foundation, in cooperation with the European Union. The reports were published in Arabic under the title "The Democracy Watch in Lebanon". Beirut, 2000 with Antoine Messarra as editor. In a study published in the Marsad p: 331-415 and done for the symposiums, Abdo Ka'ee and Suzanne Azar conducted face to face interviews with 496 randomly chosen men and women from all regions of Lebanon and from different demographics and socio-economic backgrounds. The interviews were done between February and September of 1998. They asked about the importance of liberties in Lebanon, political rights and civil rights. 
The distribution of the samples were as follows:

Gender:

$49.5 \%$ women $50.6 \%$ men

Ages:

$21.6 \%$ aged between 16-24 years

$32.3 \% 25-34$ years

$21.6 \% 35-44$ years

$13.7 \% 45-54$ years

And $10.9 \% 55$ years and older

Education:

$11.5 \%$ illiterate or elementary level

$29.4 \%$ complementary level

$31.9 \%$ secondary level

And 27.2\% University level

Professions:

$2 \%$ executives

$18.5 \%$ small business

$12.7 \%$ management

$19.2 \%$ employees

$7.3 \%$ workers

$21 \%$ housewives 
$15.5 \%$ students

And $3.8 \%$ unemployed

The results included the following:

Asked about the importance of the freedoms that form the basis of a democratic society:

$83 \%$ saw freedom of expression as important

$76 \%$ the right to work

$75 \%$ social securities

$72 \%$ freedom of thoughts and religion

$72 \%$ equality towards the law

$68 \%$ freedom to choose how to raise one's kids

$68 \%$ freedom of information

$68 \%$ freedom to choose one's work or whether to work

$66 \%$ right to free and secrecy protected elections

$60 \%$ freedom of movement and travel all over the country

$59 \%$ right to question and to hold politicians and the administration accountable

$57 \%$ right to protest or to be in the opposition

$56 \%$ right to go on strike

$49 \%$ right to assemble

$48 \%$ right to travel outside the country

$47 \%$ right to equality and to justice in judicial findings or decisions

$18 \%$ right to start a political party 
$15 \%$ right to start a professional syndicate

Of the respondents who saw that the freedom of expression as the most important, the highest percentages came from the following groups:

$91 \%$ were aged between $16-24$ years

$87 \%$ were women

$88 \%$ were students

$87 \%$ were employees

$86 \%$ were middle management

$85 \%$ had a secondary level education

Of the respondents who said that the right to work was the most important, the highest percentages came from the following groups:

$91 \%$ of those from the Bekaa valley and $90 \%$ of the respondents from Tripoli

$86 \%$ of the higher socio-economic strata

$80 \%$ of those between the ages of 16-24 and between $35-44$

$78 \%$ were women

The respondents who saw the freedom of religion and of thought as important had the highest percentages coming from the following groups:

90\% from Tripoli 87\% from East Beirut (majority Christians) and 71\% West Beirut (Sunni majority)

$83 \%$ from the higher socio-economic groups

$78 \%$ from the $44-45 \mathrm{yr}$ olds 
$78 \%$ from the workers

$77 \%$ were of the lower education level

$75 \%$ were of the university students

The respondents who saw that the freedom of assembly is essential were made up of

$82 \%$ of those who lived in the North and $63 \%$ of those who lived in the Mount Lebanon $58 \%$ were of the University students

$57 \%$ were of the middle Management

$57 \%$ were of those who were singles

$55 \%$ of those aged between 16 and 24 years of age

$54 \%$ of those from low socio-economic status

Of the respondents who chose the right to hold accountable the politicians and those who are in the administration $72 \%$ of the respondents from Mt Lebanon and the southern town of Sidon $67 \%$ of higher socio-economic status $63 \%$ of University students And 53\% had only elementary level education or below

Of the respondents who chose the equality towards laws and judgments $89 \%$ of those from East Beirut (Christian suburbs of Beirut who bore the brunt of the Syrian occupation and persecution) $90 \%$ came from Tripoli and 68\% of West Beirut $79 \%$ of the low socio-economic status 
$76 \%$ of the university students or of secondary level education

And $75 \%$ were women

For the freedom of the press, the majority of respondents came from the North of the country $94 \%$, and $78 \%$ from Zahleh the largest town and a Christian town in the Bekaa valley

$81 \%$ e of the middle management

$77 \%$ of the lower middle

$76 \%$ were of employees

$72 \%$ were women

$72 \%$ university students

For the right to free and secret elections, $89 \%$ were from the Bekaa valley, and $85 \%$ of Mt Lebanon

$74 \%$ were students

$74 \%$ of the lower mid socio economic level

$72 \%$ aged $16-24$

$71 \%$ university graduates

$70 \%$ secondary students

23 September - 5 October 2000: Information International. Opinion poll: 


\section{Post-Parliamentary Election: Between Theory and Practice.}

Of the questions asked in this poll, a relevant one to this study asked the respondents if they participated in the last parliamentary elections. A large majority of the respondents, $73.4 \%$ answered affirmatively, even if only $41.1 \%$ of the respondents believed that the elections were honest to a moderate degree, and $25.4 \%$ saw it honest to a high degree, and $17.8 \%$ honest to a low degree. Also with the high degree of participation, it is important to note that $29.3 \%$ saw that there were foreign intervention in the elections and $68.9 \%$ of these respondents specified that there was a Syrian intervention in the elections. $30.0 \%$ said they did not know if there were any interventions, keeping in mind that these elections took place during the Syrian occupation of the country. $52.4 \%$ of the respondents were satisfied with the electoral process, $31.3 \%$ were not satisfied, and $16.3 \%$ did not know.

For this survey the sample consisted of 1,350 respondents, $64.1 \%$ of which were male and $35.9 \%$ were female. $43.6 \%$ of the respondents were aged between $21-34$ years; $35.3 \%$ between $35-54$ years; and $21.1 \%$ were aged 55 and over. Marital status: $64.1 \%$ married, $31.1 \%$ single, $3.2 \%$ widowed, $1.4 \%$ divorced. Educational level: elementary and below: $9.7 \%$; intermediate $24 . \%$; Secondary $31 \%$; University + graduate studies $32 \%$; vocational studies $2.9 \%$. Monthly Household income: less than $\$ 250: 7.4 \%$; $\$ 250$ - \$500: 37.5\%; \$500 - \$1000: 40.1\%; \$1000-\$1500: 11.3\%; \$1500-\$2000: $3.1 \%$ and more than \$2000: 0.6\% keeping in mind that the minimum monthly wage is somewhere between $\$ 250$ and $\$ 300$. The margin of error is $+/-2.5 \%$. 


\section{0: Information international commissioned by the UNICRI:}

\section{Constitutional and legal faults of the 2000 election law.}

Published in An-Nahar newspaper on two consecutive days, May 12 and 13 of 2005, the study unveiled the constitutional and legal faults of the 2000 election law. It also uncovered the many infractions that took place during the days and months leading up to the parliamentary elections of the year 2000 and during the elections. The article in An-Nahar is based on the same Information International study mentioned above, and added more details to the events that took place around the 2000 elections. It also showed many instances where the system was manipulated to provide a pro-Syrian majority in the parliament and consequently a pro-Syrian government. Tens of thousands of Kurds, Palestinians and Syrians were granted the Lebanese nationality through a decree rather than a law, and whose vital records were placed in specific areas of the country to tip the population make-up in favor of the pro-Syrian candidates. (Information International study, 2000). The same study unveiled widespread "gerrymandering" throughout the electoral districts, interferences and pressure by the Syrian forces and security agents. Buying votes and buying candidates out of the process were also reported in the study. Unfair and uncontrolled access to media outlets, and the unregulated use of the media by candidates, especially those who already hold official positions, or those who possess the financial means to buy unlimited access, all of the above mentioned factors gave an unfair advantage to some candidates against others 
according to the study.

\section{December 2000: Information International: Freedom of expression.}

This survey, aimed at, among other topics, gauging the respondents' opinion about the extent of their belief in the freedom of expression in the country." The survey was done in December of 2000 in Beirut only.

To the open question whether there is freedom of expression in Lebanon, on average $60 \%$ of the respondents said yes, $29.1 \%$ said no, $2.7 \%$ did not know and $8.2 \%$ found that there is some form of freedom of expression. The respondents were from the capital distributed equally among the capital's neighborhoods with their different political leanings and religious affiliations. The highest percentages of "yes" respondents came from the Sunnis (Msaitbeh neighborhood 76.1\% saying yes), and Shiites (Shiyah neighborhood $70.1 \%$ ), while in the Christian neighborhoods the "yes" response rate ranged between a $46.3 \%$ and a $56.7 \%$, for a combined average of $51.1 \%$.

\section{September 2001. Information International. Opinion poll on Government}

\section{Performance After 200 Days and Again After 300 Days.}

“The poll covered all Lebanese territory, with 1250 questionnaires proportionally distributed in the six Lebanese Provinces (Mohafazat). In terms of gender, the questionnaire was distributed as follows: $70.6 \%$ for males compared to $29.4 \%$ for females. The respondents covered all age groups. Of the sample $14.3 \%$ were aged 18 to 
24, compared to $23.4 \%$ aged 25 to $34,31.1 \%$ aged 35 to $44,19.6 \%$ aged 45 to 54 and $11.6 \%$ over 55 years old. In terms of income, the majority of respondents (37.8\%) earn an average of US\$500-US\$1,000 per month, compared to 40.3\% who earn US\$200US $\$ 500,9.6 \%$ between US $\$ 1,000$ and US $\$ 1,500$, and $2.7 \%$ between US $\$ 1,500$ and US $\$ 2,000$. Only $7 \%$ of those polled have a monthly income of less than US\$250, while $2.5 \%$ have earnings exceeding US $\$ 2,000$. The questionnaire was distributed to different professional sectors and included the different socio-economic strata and the six main confessions.

Of the questions and results of this poll relevant to our topic, one question asked about the accountability of the present government and whom it should answer to. In the 200 days poll the results were as follows: $49.8 \%$ said the government should answer to the parliament, $29.6 \%$ said the government is responsible to the people, $9.6 \%$ did not know, $8.8 \%$ chose the NGOs. When the same poll was repeated after 300 days of the government in power $37.4 \%$ of the respondents said the government is responsible in front of the parliament, $44.4 \%$ said the people, $10.2 \%$ did not know and $7.2 \%$ said the government should answer to NGOs.

Another question that is relevant to the consolidation of democracy in Lebanon asked the respondents if they agreed on the establishment of a military government. $77.7 \%$ said No, $11.0 \%$ said yes, $8.6 \%$ did not know, and $2.7 \%$ were not concerned. Broken into confessions, $71 \%$ of the Maronites refused the possibility of a military government, 73.7\% of Greek Orthodox, $88.6 \%$ of Roman Catholics, $85 \%$ of Sunnis, $75.9 \%$ of Shiites, 
and $77.3 \%$ of Druze.

\section{September 2003: Information International: Administrative reform.}

A random sample of 600 Greater Beirut residents, were surveyed between 25-29 September of 2003. Of the respondents $72 \%$ were male and $28 \%$ were female. Age distribution was as follows $26.6 \%$ aged $18-24,29 \%$ aged $24-34,21.6 \%$ aged $35-44$, $12.1 \%$ aged $45-54$ and $10.7 \%$ over 55 years of age. The survey addressed the need for an administrative reform and how to go about it. To the question of how would real administrative reform be realized, the highest rate of respondents, $20.6 \%$, called for the application of the Illicit Wealth Law. 20.2\% wanted the elimination of the confessional system of politics, $17.9 \%$ called for the adoption of a merit based system, and $16.7 \%$ proposed the dismissal of corrupt employees. $12 \%$ suggested restructuring the public sector and $11.4 \%$ called for an end to politicians' interference in the administration. What is mostly relevant to our study is the necessity to adopt a merit system in the public sector which implies getting rid of the confessional system in politics, an issue at the root of the challenge to the consolidation of democracy in the country. There were many calls recently to put an end to the political confessionnalism. Those calls were set into motion in 1992 as a result of the Taef accord, and after the new parliament was elected according to the new division of seats, where half of the parliament seats go to the Christians in all their different rites, and the other half going to those of the Muslim confession. However, putting an end to the political confessionnalism, and even though it was called 
for in the Taef accord, was never put into practice. Another call by the speaker of the Parliament in 2009 to start the phasing out of the political confessionalism was met with skepticism, cynicism, and accusations of hidden motives.

\section{April 2003: Information International: The Lebanese war and its purpose.}

A survey published in An-Nahar newspaper on the $22^{\text {nd }}$ of April 2003. On the anniversary of the start of the Lebanese war, April 13, a survey of a sample of 600 Lebanese citizens in the greater Beirut area of $59.8 \%$ males and $40.2 \%$ females, ages ranging from 15 to 55 years $(19.4 \%$ aged $15-24$ years, $32.1 \%$ aged $25-34$ years, $28.8 \%$ aged 35-44 years, $11.9 \%$ 45-54 years, and 7.8\% over 55 years of age) with incomes ranging from $\$ 2000.7 \%$, between $\$ 500$ - $\$ 100038.7 \%, 22.7 \%$ an income between $\$ 500$ $\$ 200,20.3 \% \$ 1000-\& 1500$ and $5.9 \%$ over $\$ 2000$, were asked about the causes and results of the war and the Taef accord. The survey was conducted between the $10^{\text {th }}$ and the $13^{\text {th }}$ of April.

$10.2 \%$ only believe that the war accomplished the purpose for which it was started $87.7 \%$ believe that it did not accomplish any of its goals whatever these were. These results were not influenced by the religious affiliation of the respondents. $49 \%$ of those surveyed suffered damages from the war, the majority of them $(32 \%)$ lost their homes.

$44.5 \%$ are for bringing to justice the leaders of the different militias and political parties that participated in the war. 
$37.8 \%$ believe that the Taef accord brought a short temporary end to the war while $32.5 \%$ believe that it brought a long temporary end.

\section{Antelias 12-13-14 December 2003. The Fourth National Convention on} Democracy and Youths Participation in Public Life.

Present at the convention were many university professors from different universities and different confessions. There were also students from countries other than Lebanon who participated in the convention: they came from Jordan, and Syria, but mostly from Lebanon and all of its different mohafazats (counties). Different faiths and both genders were equally represented.

The young participants insisted on having or creating the "human-citizen society called civil society". (p. 8 of the published study)

The cornerstone of democracy and of the results of the conventions could be summarized in the importance of the youths' participation in public life in its "three-pronged foundation: democracy, participation and public life" (: 16)

\section{4: Information International: Elections are necessary even when}

fraudulent. A study published in iMonthly of August 2004. A stratified sample of 600 residents in the Greater Beirut area, between 16 - 21 of June 2004, was interviewed face to face. The sample was made out of $51.2 \%$ males, $48.8 \%$ females. $21.8 \%$ of the sample were aged $18-24,30.5 \%$ aged $25-34,23.4 \%$ aged $35-44,12.5 \%$ aged $45-54$ and $11.8 \%$ 
over 55 years of age.

The majority of the respondents, $72.5 \%$, support the principle of elections in principle: $51.2 \%$ of those who responded see that elections allow for the opportunity to freely express opinion and $21.3 \%$ see the elections as an occasion to hold the representatives accountable.

$13.3 \%$ of the respondents see the elections as favoring the rule by the majority rather than by those who are competent and $13 \%$ see it as a futile exercise in a developing country. This result came even when $70.2 \%$ of the respondents saw that the 2000 parliamentary elections were fraudulent. Even with the conception that there are widespread irregularities and fraud in the elections they are still worth having.

It is worth noting that $46.9 \%$ of the respondents make their own list of candidates rather than using the full lists as they appear. That shows independence in thought and a good exercise of the voting right rather than blindly following the official lists. Also $44.7 \%$ of those polled favor an intellectual as a candidate, compared with $31.3 \%$ who prefer a veteran politician, $11.2 \%$ prefer a businessman and $6.6 \%$ prefer a religious candidate. $6.2 \%$ prefer a military man.

\section{4: Beirut center for Research and Information: political parties and} confessionalism.

A report published in October of 2004 about the political parties states that: the political parties in Lebanon could play a major role in steering the country away from 
political confessionnalism and from the system built on religious affiliations. However, the fact that the political parties in Lebanon have a "religious identity" causes a major obstacle to the move towards political secularism.

The overwhelmingly religious identity of the political parties leads to a membership that is limited to one religious affiliation, stamps the political party with the religious affiliation of its leader, and makes it difficult for that leader to play a national role separately and away from the one in his/her religious group.

The political parties are also built around the personality of the leader rather than around a political philosophy. The leader is consequently followed blindly without questioning and the political party is then treated as property handed down from father to son.

(Beirut Center for Research and Information, Issam ISMAEL, Oct 2004)

December 2004. Information International. Opinion poll: The Extension of President Lahoud term, the new government and resolution 1559. iMonthly. Issue 30. The election of the Lebanese President is governed by the dictates of the Constitution. Renewing his mandate during the Syrian occupation through an amendment of the related article of the Constitution was a cause for disagreement among the Lebanese and was not supported by a large number of them. The Information International poll looked at the Lebanese attitude towards this extension of the President's mandate. $51.8 \%$ of the respondents did not see a problem with the term 
extension, while $35.8 \%$ opposed it, and $12.4 \%$ replied "I don't know". It is important to note the majority of the Druze, $66.7 \%$, and of the Maronite respondents, $52.9 \%$ of them, opposed the extension and the manipulation of the Constitution to do so. On the other hand, majorities of the Shiites respondents, $61.3 \%$, and of Roman Catholics (60.7\%) were for the term extension.

The poll also asked the respondents about disarming Hezbollah: "49.5\% of respondents are against disarming Hezbollah, versus 38.7\% who support the move and $11.8 \%$ who are Indifferent." The majority of the Shiite $(85.5 \%)$ and Sunni $(63.1 \%)$ respondents were against the disarming, with a majority of the Maronite respondents (72.6\%) and the Catholics (78.7\%) and Orthodox (54.5\%) were for disarming the "Hezb".

A notable result is that $75.9 \%$ of the respondents were in favor of the presence of female ministers in the government. For this poll, which was taken 3-8 November 2004, the sample was "of 1,250 people distributed across Lebanon, in face-to-face interviews. The gender distribution was $55.7 \%$ male and $44.3 \%$ female. However, $5.8 \%$ of females approached refused to participate, mainly indicating "no interest in politics". The age distribution of respondents was as follows: $15.1 \%$ between $15-24$ years, $26.7 \%$ between $25-34,27.3 \%$ between $35-44,19.5 \%$ between $45-54,8.6 \%$ between $55-64$ years and $2.9 \%$ for those over 65 . The poll's margin of error is $\pm 2 \%$." 
poll published in iMonthly in May of 2005, issue 35. iMontly polls the Lebanese: $84.7 \%$ for the election in May, $74.1 \%$ with the Syrian Withdrawal. The poll asked a sample of Lebanese in the Greater Beirut area between 7-11 April 2005. "The majority of the respondents $(83.6 \%)$ said they would participate in the elections, while $7 \%$ had not decided yet and $9.7 \%$ stated that they would not take part."

\section{5: Zogby International: Attitude towards democracy.}

The Zogby study was done through face to face interviews with randomly selected citizens in several Arab countries including Lebanon where six hundred randomly selected citizens were interviewed. The study was commissioned by the Center for Democracy and the Rule of Law. Of the questions asked three are of interest for the purpose of this thesis to test the Lebanese attitude towards democracy:

- Do you identify with the Lebanese identity first or with the religious identity first?

- Do you conceive a political regime in Lebanon other than democracy?

- Do you trust an elected Islamic government to follow the rules of democracy?

In response to the last question, whether to trust an elected Islamic government to follow the rules of democracy, $36 \%$ of the respondents in Lebanon did agree. Christians in Lebanon were most skeptical - just one in five said they believe an Islamic government would abide by the laws of a democracy.

The majority of the respondents in Lebanon identify with the Lebanese identity first. This result is echoed by the 2007 Springhints -Mind the Gap survey on this specific 
question. Also a majority of the respondents in Lebanon did not see a regime in Lebanon other than democracy.

\section{1-13 Feb. 2006: Statistics Lebanon: Freedom to demonstrate.}

A poll done through direct interviewing of a cluster sampling of 400 respondents residing in Beirut, Mount Lebanon, the South, North and the Bekaa valley, divided equally by gender and with a variety of age groups. The different social status and education levels were also equally represented. One question that is relevant to the purpose of this thesis addressed the freedom of demonstration: $49.25 \%$ of the respondents are opposed to the decision by the government to ban demonstrations in the time being.

\section{8-22 March, 2006 : Statistics Lebanon: Extending the president's term.}

A poll done through direct interviewing of a cluster sampling of 400 respondents residing in Beirut, Mount Lebanon, the South, North and the Bekaa valley, divided equally by gender and with a variety of age groups. The different social status and education levels were also equally represented. From the questions asked in this survey one is relevant to the topic of this thesis: it asked the respondents whether they were in favor or against the extension of the term of the current president at the time. The extension is against the dictates of the Lebanese Constitution. $80.7 \%$ of the respondents were against the extension. The percentage was high both among the Christian respondents (89.10\%) and Muslim respondents (75.41\%) alike. Another sign of the 
Lebanese citizens' attitude that sees that no other system is acceptable except democracy, and what is dictated by the country's constitution.

\section{9-24 April, 2006 : Statistics Lebanon: the army is the only armed forces in}

\section{the country?}

Direct interviewing of a cluster sampling of 400 respondents residing in Beirut, Mount Lebanon, the South, North and the Bekaa valley, divided equally by gender and with a variety of age groups. The different social status and education levels were also equally represented. From the questions asked in this survey one is relevant to the topic of this thesis: it asked the respondents if they think the Lebanese army should be the only armed forces deployed in the country. A majority of $78 \%$ answered "yes", $19 \%$ answered no. the majority of those responding with a "yes" are Christians $(95.51 \%$ of the Christian respondents said yes) while only $39.45 \%$ of the Shiites saw that the army should be the only armed forces deployed in the country.

\section{August 28- September 1st, 2006 : Statistics Lebanon: the attitude towards the}

army._A poll done through direct interviewing of a cluster sampling of 400 respondents residing in Beirut, Mount Lebanon, the South, North and the Bekaa valley, divided equally by gender and with a variety of age groups. The different social status and education levels were also equally represented. From the questions asked in this survey the one that is relevant to the topic of this thesis asked the respondents if they thought the 
Lebanese army capable of defending Lebanon against Israel if given the necessary arms and equipment. $80.25 \%$ of the respondents believe that the Lebanese army is capable of defending Lebanon if provided with the proper weaponry.

\section{October 28 and November $1^{\text {st }}$ 2006: Statistics Lebanon: Support for the}

\section{army.}

Another poll conducted by Statistics Lebanon of 400 citizens spanning the whole country and including members from different age groups and socio-economic and religious affiliations, between October 28 and November $1^{\text {st }}$ had results that confirmed that same idea, with $82 \%$ of the respondents approving of the Lebanese army getting support and weapons from the west, and $67.75 \%$ of the respondents want the Lebanese army to secure the borders. The support came mostly from the Druze respondents (92.31\%), the Christians (81.53\%), followed by the Sunnis (75.93\%) with the Shiites having the lowest approval rate for the army deployment (33.94\%) keeping in mind that Hezbollah is made up of Shiite membership. Also it is important to note the fact that this poll took place right after the Israeli invasion of the country and its destructive war against Hezbollah.

July 26, 2006. Pew Research, Pew Global Attitude Project: Muslims’ attitude towards religion and politics.

A survey that looked at Muslims attitudes in several Muslim countries in the 
Middle East that included Morocco , Jordan, Lebanon, and Turkey. Lebanon's Muslims: Relatively Secular and Pro-Christian But Support for Terrorism and Anti-Semitism are Widespread. "Muslims in Lebanon are less likely to identify primarily with their religion, rather than with their country, with equal numbers saying they think of themselves first as Muslim (30\%) and saying they identify primarily as Lebanese (30\%)." Also, in 2006 Lebanese Muslims and Christians have positive attitude towards each other: $86 \%$ of Muslims have "a favorable opinion of Christians, by far the highest rating of Christians by any Muslim public." $82 \%$ of Christians have a "positive view of Muslims". As for the importance of religion in their lives 54\% of Lebanese Muslims said it was very important compared to $96 \%$ of Moroccans for instance or $86 \%$ of Jordanians.

\section{November 2006: Information International in collaboration with the Social} and Behavioral Sciences Department in the American University of Beirut: The

\section{Lebanese follow their leaders; prefer peace, but are ready to fight for their family, country, and religion.}

“The poll was conducted between November 18-27, 2006 on 1500 women and men $(55.1 \%$ of the respondents were male and $44.9 \%$ were female) in the different Lebanese areas respectively and according to the voters in each areas, also respectively and the numbers of voters of each confession in these areas. Respondents were of different ages and different social levels and incomes." The first section of the poll looked at personal and social identity, using a 7-point scale with 0 being not at all and 6 
being "to a very large extent". The most highly endorsed identity was the family with an average rating result of 5.38 ( 6 being the highest) followed by country at 5.31 , then religion with 4.75. The Islamic Nation or the Arab world had the lowest ratings of 3.24 and 2.96 respectively.

The second section of the questionnaire measured the degree to which the Lebanese favor their own confession, are loyal to and follow their leaders, and their religiosity. The data revealed that they have "strong leadership affiliation, are highly confessional, highly religious and perceive their group to be threatened by other groups."

\section{October 2006. Information International: opinion poll: the Lebanese divided} behind their leaders over critical matters.

800 persons were polled with an even distribution among confessions and from the various mohafazats (counties). The gender distribution was $61.1 \%$ male and $38.9 \%$ female due to the refusal to participate on the part of the females. The age distribution was $24.4 \%$ aged $18-24,23.5 \%$ aged $25-34,20.7 \%$ aged $35-44,16.9 \%$ aged $45-54,10.7 \%$ aged 55-64, and 3.8\% over 65 years old. The margin of error was $+/-3$ with a $95 \%$ confidence interval.

The relevant results of the poll showed the willingness of the Lebanese to "show remarkable and strong loyalty to their leaders. They also have shown a great resistance to any change in their loyalty, signifying the rigidity of Lebanon political and social 
symbols." Another interesting finding of this poll is that the Lebanese tend to "perceive issues through the eyes of their leaders more than their confessions." $25 \%$ of the respondents had answers that "diverged from the confessional-patronage affiliation."

"Age, gender and education do not significantly affect the political opinions of the Lebanese people on critical national issues."

\section{August 9, 2006. An-Nahar survey in cooperation with the YMCA, the}

\section{International Association for Administration and Training, and the Colloquium for Parliamentary Dialogue: The definition of democracy and source of information.}

The survey was published in the An-Nahar annex Nahar el-Shabab. A sample of 1050 randomly chosen Lebanese from all sections of society were polled, of which 779 were valid. The respondents were aged from just under 18 years of age to over 47 years old. Males made up 55.2\% of the total number of respondents and $44.3 \%$ were females. The margin of error is between 0.5 and 1.2. The survey showed that $90 \%$ of all surveyed knew the definition of democracy as the rule of the people by the people. These respondents who knew the definition had at least a high school education and from all social ranks. Those who could not give a correct definition of democracy were either illiterate or with an elementary level education.

Other than education another source of informing is the media: to those between 33 and 39 years of age $59.3 \%$ get their information from the media, with $53.8 \%$ of those under 18. 
Asked if they had practiced democracy in one way or another $98.4 \%$ of those over 47 years of age answered affirmatively, with 92.4 of postgraduates. Half of the young people who were polled saw that joining a political party is a road to leadership. $94.8 \%$ of the all surveyed respect others' opinion with only $1.8 \%$ believe in using force to impose their opinions.

\section{Spring 2007: Le printemps des interrogations (Springhints - Mind the} gap):Attitude of Lebanese towards different aspects of democracy.

A major study published in the Spring of 2007. It addressed the attitude and the opinion of the Lebanese towards democracy. The Springhints - Mind the Gap study surveyed university students and Internet users. The ages were mostly between 18 and 30 years old. Even though the sample did not include all age levels but it did include a cross section of the population that included all major political parties affiliation, different socio-economic levels, and all regions. The survey posed a total of 31 questions. I will cite the questions that serve the purpose of this thesis, and skip the ones that are not closely relevant to our topic.

The first question asked: "In your opinion, does the Lebanese Constitution complicate by its nature the political life?" Interestingly enough $77.8 \%$ of the university students and $77.0 \%$ of the internet respondents answered affirmatively. They considered the confessional system instilled by the Constitution an obstacle in the way of an egalitarian democratic regime, distributing government and parliamentary seats according 
to a complicated power sharing formula among different religions and confessions.

Question 2 asked if the required consensus between political-religious factions on key issues, if that consensus got in the way of an objective and constructive treatment of social problems (education, justice, security, health care, economy, etc.)?

The answer was a $61 \%$ yes among university students and $62.6 \%$ among internet respondents.

Question 3 asked if the representation according to the religious and confessional affiliation, since it is born with the individual citizen, if it leads to allegiance to the relatives, persons and families rather than to ideas and political programs.

$54 \%$ of the university students and $63.6 \%$ of the internet respondents answered affirmatively.

Question 5 asked if the project of political "deconfessionnalisation" or moving away from confessionnalism towards "laïcité" as it is stipulated in the Taef accord, contradicts the principles of consociational democracy, or as it is described in the survey, of "consensual democracy"?

$41.4 \%$ of university students and $43.3 \%$ of the internet respondents said yes, while $58.6 \%$ of the university students and $56.3 \%$ of the Internet respondents answered negatively. A slight majority then sees that there is no contradiction between the Taef agreement's calling for an end to political confessionalism and the nature of the consociational democracy.

The laiicité in Lebanon is seen very differently from the one in say France where there is a 
complete separation between the state and the Church as a result of the French revolution. In Lebanon the religion is closely related to how the individual citizen sees himself/herself. The religion is an integral part of one's heritage, and "our respect of the religious takes on the dimension of loyalty to one's past a loyalty that is as natural as it is gratifying." (Springhints, $2007: 41)$

Question 16: along those same lines, of the results of confessionalism, asked about what would threaten the long term presence of the different religious communities in Lebanon, the majority or $57 \%$ of the university students and $57.8 \%$ of the Internet users answered the actual confessional system, $25.7 \%$ of the university students and $25.3 \%$ of the Internet users saw it threatened by the laïcité, and $17.3 \%$ of the university students and $17 \%$ of the Internet users saw the threat in the deconfessionalization.

Question 7 made up of 4 sub-questions addressed the legislative modifications needed to alleviate the allegiance to the confession in favor of that to the country. Subquestion 7-4 asked specifically about laïcité. It defined laïcité as the total separation between civil and religious instances. $60.4 \%$ of university students and $72 . \%$ of Internet respondents answered "yes, immediately" with $17.7 \%$ of university students saying may be some day and $21.9 \%$ answering negatively, versus $13.0 \%$ of Internet respondents saying may be some day and $14 . ! \%$ saying no.

Question 9 addressed the possibility of the Islamization of the country's laws by asking if it is possible that one day the Coranic law would "impregnate the Lebanese Constitution". A majority of $71.9 \%$ of university students and $70.5 \%$ of Internet 
respondents answered negatively.

Question 12 asked if in a country where freedom of expression is protected by the Constitution, whether the religious figures should be spared from criticism, comic jabs and satire. $62.9 \%$ of the university students and $64.7 \%$ of the Internet users said yes.

Question 25 asked the respondents about their overall impression of laïcité: $24.2 \%$ of university students saw it as the marginalization, almost oppression, of religions, $50.3 \%$ saw it as an inescapable dimension of any real democratic practice, $38.8 \%$ as a protection of religious practices in all their diversity, and $15.3 \%$ as an easing of moral values. $14.1 \%$ of Internet users saw it as a marginalization of religion, $51.7 \%$ as dimension of democratic practices, $43.7 \%$ as a protection of religious practices and $11.9 \%$ as a loosening of the moral values.

\section{$27^{\text {th }}$ of July, 2007: An-Nahar newspaper poll: opinion polls show Lebanese'} primary allegiance to leaders not to programs.

The poll showed that the Lebanese people's primary allegiance is to the "za'im" or leader rather than to the political programs. A study conducted by Information International, surveying "a sample representing all regions and sections of Lebanese society" showed that $65.5 \%$ of the respondents say they show allegiance to the leader. There is a tendency to worship the leader, as if they were "half-deity". They are followed blindly even if when they switch position. They also fill the role of providing services to their followers in the absence of a government. The void left by the 
incompetence or lack of basic services normally provided by a functioning government is filled by the "za'im". All of the above mentioned facts lead to the immunity of the "za'im" against accountability and having to answer to the electorates.

\section{June 2006 to April 2008: The Lebanese Opinion Advisory Committee}

\section{(LOAC) in a collaborative effort with the International Republican Institute (IRI),} and Statistics Lebanon: Attitudes towards the national identity, voting and democratic institutions.

This study was through a series of opinion polls aver a period of time extending from June 2006 to April 2008. The polls examined the Lebanese Public Perceptions and attitudes towards the National Identity, Voting and Democratic Institutions.

The first opinion poll of the series took place during the period from June 14 to July 10 of 2006. It was conducted shortly before the Israeli - Hezbollah war in 2006. It focused "on public perceptions of the Lebanese national identity, voting and democratic institutions." The sample was of 2400 respondents distributed geographically across the country in urban and rural areas, and among different socio-economic groups. The ages were of 18 years and above. The survey, conducted door to door, found that the Lebanese "express firm national allegiance, viewing themselves primarily as Lebanese and secondarily as a member of a sect or a religion." $75.7 \%$ of the respondents said that they were Lebanese first and then a member of their religious sect. The poll also found that "There is a strong belief in democracy and voting among Lebanese, particularly as 
preferable to autocratic or theocratic alternatives." $94.4 \%$ of the respondents found that "voting is a duty for every citizen who has the right to vote." which shows a strong commitment on the part of the citizens to the democratic regime. $79.1 \%$, a strong majority, agree "that voting in elections is important and that the voting process can change reality." " $85.4 \%$ of the respondents believe that the purpose of voting is to select the right people to rule Lebanon, regardless of their political party or sect."

$89 \%$, "the overwhelming majority of those polled" and "across sectarian lines" support a "democratic government and reject the idea that extenuating circumstances would justify a non-democratic government."

"A majority of the respondents support the Taef Agreement, which states that Muslims and Christians should receive an equal number of the 128 seats in the Parliament."

Other notable results:

$91.4 \%$ of the respondents consider participation in the elections to be a way to "improve the future."

$80 \%$ said they would ultimately make their own decisions when voting rather than follow the directives of the religious leader. Shiites are the most likely group to follow the instructions of their religious leader, $44.2 \%$ of the Shiites said they would consider it as "their duty to follow a religious order, compared with $12.8 \%$ of Sunnis, $12.6 \%$ of Christians, and $9.9 \%$ of the Druze." $62 \%$ of the respondents "prefer voting for candidates representing political parties or 
groups"

November 15 - December 11, 2006. Public opinion polls, a collaborative effort among the International Republican Institute (IRI), the Lebanese Opinion Advisory Committee (LOAC), and Statistics Lebanon: Perceptions of politics, leadership, and current cvents in Lebanon.

The sample was of 2400 respondents distributed geographically across the country in urban and rural areas, and among different socio-economic groups. The ages were of 18 years and above. The survey, conducted door to door, found a "high degree of nationalism and a strong belief in the importance of voting and the democratic process". A clear majority (86\%) of the respondents, "from all regions and sects- opt for nonviolent, democratic and legal means of achieving their political ends." $13 \%$ said "they would participate in a potentially violent demonstrations in order to achieve their objectives."

"While the vast majority of Lebanese are not members of a political party, $78 \%$ of the respondents expressed a preference when asked which political party best represented their point of view." Asked which political party best represented them, "the answer "no one" received the highest percentage of $21.92 \% . "$

"the overwhelming majority of Lebanese support peaceful methods for political transition and reject the use of violence. A clear majority (86\%) - from all regions and sects - opt for non-violent, democratic and legal means of achieving their political ends." 
Most of the respondents do not plan on joining a political party in the future and are cynic about the parties' role. On the other hand, " the majority of those polled believe that non-governmental organizations can have a positive impact on public policy in Lebanon. “

\section{May 14 - June 11, 2007: Public opinion polls, a collaborative effort among the International Republican Institute (IRI), the Lebanese Opinion Advisory Committee (LOAC), and Statistics Lebanon: Perceptions of politics, leadership and events.}

The polls looked at Perceptions of Politics, Leadership and Current Events in Lebanon.

The sample was of 2400 respondents distributed geographically across the country in urban and rural areas, and among different socio-economic groups. The ages were of 18 years and above. The survey, conducted door to door, found that "national identification continues to be strong. Seventy-one percent of the respondents claimed they were 'Lebanese first, member of a religious group second'."

"Significant numbers of Lebanese believe that a solution to the crisis can come through a peaceful process. A majority of respondents $(57 \%)$ believe that the solution to the current political crisis can be achieved through peaceful means; however, $29 \%$ fear that the solution will come through some degree of violence, and $14 \%$ think it will lead to or result in open armed conflict." $35 \%$ of the respondents see that the primary cause of 
the current conflict and the sit-in in downtown Beirut is a result of an "international and regional conflicts".

$70 \%$ of the respondents support the current "arrangement of equal representation between Christians and Muslims, which was put in place with the Taef Accord". This number "represents a 15 point increase in support of the Taef Accord since the November - December 2006 survey."

Political parties “tend to receive blame for Lebanon's troubles. Most respondents do not belong, and would not consider belonging, to any political party. One exception is an extraordinary high level of potential participation among young people in Lebanon. Of those who would consider joining a political party $72 \%$ are between the ages of 18 and 39. That is more than twice the number than would consider joining a party in any other age category."

"While $63 \%$ believe that religious leaders should refrain from active involvement in politics through making political statements, more than seven in ten respondents $(72 \%)$ believe that political leaders should consult with religious leaders.

\section{December 29, 2006 to January 2, 2007: Statistics Lebanon: Sit-in in the}

\section{downtown area.}

After the political protests against the government, a survey using direct personal interviews and cluster sampling from a sample of 400 respondents residing in various 
areas of Lebanon and comprised of an equal number from both genders and a variety of age groups. It also was made up of a variety of income levels, educational levels and sects. Asked about the demonstrations and sit-in in the downtown area to show opposition to the government the responses were that $33 \%$ strongly support the sit-in, $29.75 \%$ strongly oppose, $18.5 \%$ oppose, and $18 \%$ support, $0.75 \%$ refused to respond. (51\% support and $48.25 \%$ oppose the sit-in).

Asked if taking to the streets was an acceptable way to change a regime "as opposed to doing it through democratically elected institutions, $43.75 \%$ answered affirmatively, $41 \%$ answered negatively, $13.25 \%$ answered "I don't know", and 2\% refused to respond."

May 7-14, 2007:Information International : opinion poll: The Lebanese less supportive of the ongoing sit-in: divided over the presidential elections and with the Tribunal but with conditions.

This poll was taken 5 months after the previous one done by Statistics Lebanon. In the Statistics Lebanon survey the majority of the respondents were for the sit-in in the downtown area as a sign of protest against the government. In the Information International survey, five months later, the results seem to show a different attitude among the respondents towards the sit-in. The Information International survey was conducted between May 7 and May 14, 2007. The survey was published in the issue 60 of iMonthly, the printed voice of Information International. The opinion poll was conducted "on a sample of 1000 citizens in different Lebanese areas, with a proportional 
distribution based on the number of residents and the electoral size of each confession in each Mohafaza." The respondents were $57.5 \%$ male and $42.5 \%$ females, $20.6 \%$ were aged between $18-24$ years old, $30.9 \%$ between $25-34$ years old, $25.1 \%$ between $35-44$ years old, $14.6 \%$ between $45-54$ years old, $6.5 \%$ between $55-65$ years old, and $1.9 \%$ above 65 years of age. $0.4 \%$ refused to reveal their age. "Respondents were distributed in all social and professional categories. The margin of error was +or- $1.8 \%$ The poll had the following results:

More than half $(56.8 \%)$ of the respondents were against the sit-in in the downtown area. It is important to note that the majority of the Shiite respondents $(77.5 \%)$ were for the sit-in with only $18 \%$ of the Shiites being against it. $87.25 \%$ of the Druze respondents were against the sit-in, $87 \%$ of the Sunnis, and $65.2 \%$ of the Maronites.

\section{November 2007. The Center for Strategic Studies at the University of} Jordan in collaboration with Statistics Lebanon. Views of democracy, views of religion, views of citizenship, views of public institutions.

The project, the Arab Barometer, conducted surveys in many Arab countries, aimed at establishing a data base in those countries "regarding politics, religion, culture and society." In addition to Lebanon, the countries were the Barometer was started were Jordan, Morocco, Algeria, Egypt, Yemen, Palestine, and Kuwait with cooperation with the University of Michigan - Ann Arbor and Princeton University.

The sample in Lebanon was made up of 1200 residences and distributed 
throughout the country. The Results of the Arab Barometer Survey in Lebanon, that are relevant to the purpose of this thesis, showed a majority of the Lebanese believing that democracy is the only acceptable regime in the country, that very little could justify the trampling of human rights and freedoms, and that belonging to the country precedes the clan or the family. The survey also showed a distrust of the politicians (members of the parliament, the prime minister or the political parties). The detailed results were as follows:

\section{"1. Views of Democracy.}

a. If you have to choose one, what is the most important feature of democracy?

The ability to change governments through elections $31.8 \%$

Freedom to criticize those in positions of power $14.8 \%$

Reducing the gap between rich and poor $19.8 \%$

Providing basic needs, such as food, housing, and clothing to all individuals $27.7 \%$

b. What is the second most important?

The ability to change governments through elections $15.6 \%$

Freedom to criticize those in positions of power $20.7 \%$

Reducing the gap between rich and poor $22.9 \%$

Providing basic needs, such as food, housing, and clothing to all individuals $34.9 \%$

c. Do you agree or oppose the following statement: Democracy may have its problems but it is better than any other form of government. 
Agree Strongly 46.9\%

Agree $42.1 \%$

Disagree $6.8 \%$

Disagree Strongly 1.1\%"

Other $3.2 \%$

d. To which degree to you believe it is justified to disrespect human rights in Lebanon for security?

To a large degree $4.1 \%$

To a moderate degree $10.4 \%$

To a small degree $9.5 \%$

Not justified $72.2 \%$

Other $3.9 \%$

e. What is the appropriate political system for Lebanon: A Parliamentary system were various parties compete against one another through elections

Very appropriate $36.5 \%$

Appropriate $30.8 \%$

Appropriate to a certain extent $11.6 \%$

Not appropriate at all $17.9 \%$

Other $3.2 \%$

2. The Place And Role Of Religion In Public And Private Life

a. What is your primary social or geographic group 
Family/Clan/Tribe $44.8 \%$

City/Village/Camp in which you live $1.8 \%$

Governorate in which you now live $1.2 \%$

Lebanon generally $47.2 \%$

Other $5.0 \%$

b. To what extent do you think the following statements are appropriate:

Religious leaders have an impact on political decisions

Agree strongly $3.0 \%$

Agree 14.3\%

Disagree $35.9 \%$

Disagree strongly $45.3 \%$

I don't know $1.2 \%$

c. To what extent do think the following statements are appropriate: Religious practices are practices that must be separated from economic and social life

Agree strongly 53.6\%

Agree $28.1 \%$

Disagree $11.8 \%$

Disagree strongly $4.9 \%$

I don't know $1.1 \%$

Other $3.2 \%$

\section{Focus of Citizenship}


a. Did you participate in the last parliamentary elections which took place

Yes $61.9 \%$

No $35.3 \%$

Other $2.8 \%$

b. In general, what is your interest in politics

Very interested $25.9 \%$

Interested $32.8 \%$

Interested a little $21.9 \%$

Not interested 19.1\%

c. Do you agree or disagree with the following statement: Politicians are

interested in the needs of the average citizen?

Strongly Agree 5.3\%

Agree $12.3 \%$

Disagree $35.6 \%$

Strongly Disagree $44.1 \%$

Don't know $1.5 \%$

4. Views Of Public Institutions And Confidence In Their Efficiency

a. I will name several institutions, I want you tell me your degree of confidence in each of these institutions: the Prime Minister

A high level of confidence $14.9 \%$

A moderate level of confidence $16.2 \%$ 
A small level of confidence $10.8 \%$

Not confident at all $55.8 \%$

Don't know 1.4\%

b. I will name several institutions, I want you tell me your degree of confidence in each of these institutions: The Parliament

A high level of confidence $12.4 \%$

A moderate level of confidence $26.8 \%$

A small level of confidence $16.6 \%$

Not confident at all $41.6 \%$

Don't know 1.7\%

c. I will name several institutions, I want you tell me your degree of confidence in each of these institutions: Political parties

A high level of confidence $5.8 \%$

A moderate level of confidence $15.4 \%$

A small level of confidence $15.4 \%$

Not confident at all 59.7\%"

\section{7: Information International: opinion poll: Military takeover,}

\section{Hezbollah's arms and Hezbollah and the Army.}

“The Majority of Lebanese Support Holding a Referendum on Lebanon’s Identity. $62.6 \%$ Favor a Temporary Military Takeover. iMonthly, issue 65 : 2-8 
December $1^{\text {st }}, 2007$. The poll was conducted October 22-28, 2007 on a sample of 2000 Lebanese distributed by Qada's based on the electoral size and the confessional distribution which was as follows: Maronites 22.6\%, 7.9\% Orthodox, 5.2\% Catholics, 3.1\% Armenian Catholics, 1.2\% Christian minorities, 27.2\% Sunnis, 26.1\% Shiites, 5.6\% Druze, $0.9 \%$ Alaweetes, $0.2 \%$ did not specify their confession. The sample was divided equally gender wise, and distributed equally among the different age categories and income levels.

One of the questions addressed the respondents' attitude towards Hezbollah's arms. $59.4 \%$ of the respondents agreed with the statement that the arms were necessary to face Israel until the liberation of the Sheba'a farms, $34.3 \%$ did not agree with that statement and $6.3 \%$ did not know. $36.6 \%$ see the arms as not necessary after Israel's withdrawal form the South, $54.1 \%$ do not agree with that statement, and $9.3 \%$ did not know. The breakdown of these numbers along the confessions lines were as follows: 91.6\% of the Shiites consider Hezbollah's arms as necessary to face Israel, while only $22.5 \%$ of the Druze, $34.6 \%$ of the Catholics, $53.8 \%$ of the Orhtodox, $55.5 \%$ of the Sunnis and $42.8 \%$ of the Maronites agreed with that.

Whether Hezbollah's arms reinforced the Shiites at the expense of other confessions in the country: $36.5 \%$ agreed with that statement, $51.3 \%$ did not see it that way, and $12.2 \%$ did not know. On the question that the fact that Hezbollah is armed played into the Syrian-Iranian agenda the respondents on both sides of the issue were equally divided with $42.7 \%$ not agreeing with that statement and $42.7 \%$ agreeing with it, 
and $14.6 \%$ did not know. $62.2 \%$ see that Hezbollah should merge with the regular Lebanese army, $21.8 \%$ against that and $16 \%$ did not know. Looking at the responses to this question along confessions lines: only $49.1 \%$ of the Shiites agree with that, compared with $78.4 \%$ of the Druze, $71.9 \%$ of the Sunnis, $56.7 \%$ of the Catholics, $57 \%$ of the Orthodox, and $61.4 \%$ of the Maronites. On the other hand $8.5 \%$ see that Hezbollah should be disarmed against $82.9 \%$ who disagree with the disarming of the Hezb and $8.6 \%$ did not know.

To the question "In your opinion should the Lebanese army take control of the country for a temporary period?" $62.7 \%$ of the respondents answered affirmatively, $30.5 \%$ were against the idea, and $6.8 \%$ did not know. Of the Maronites respondents $60.5 \%$ were for compared with $66.5 \%$ of the Orthodox respondents, $43.3 \%$ of the Catholics respondents, $50.9 \%$ of the Sunni respondents, $85.4 \%$ of the Shiites respondents, and only $22.5 \%$ of the Druze respondents.

The $62.7 \%$ of the respondents agreed with the idea that the army should take over the control of the country for an interim period of time and only until the election of a president and the formation of a new cabinet are achieved. It is important to note that it is only a temporary measure and a result of a long stalemate and a sit-in in the capital that crippled its lively downtown area with all its businesses, restaurants and tourist attractions for over a year.

March 28 - April 8, 2008: Public opinion polls, a collaborative effort among 


\section{the International Republican Institute (IRI), the Lebanese Opinion Advisory}

\section{Committee (LOAC), and Statistics Lebanon: the Taef, the Constitution and the}

\section{Confessionalism.}

A follow-up to the previous polls conducted in June and December 2006 and in May 2007. The same procedures were followed with a sample of 2400 Lebanese comprised of "proportional subsets of the major confessions - 924 Christians, 660 Sunnis, 660 Shiites and 150 Druze. Proportional quantities of other variables - age, sex, region, and income level - are also factored into the full sample."

The majority of the respondents to this poll $(66 \%)$ affirmed the necessity to keep what the Taef agreement established in equally dividing up the parliament seats between Christians and Muslims. Asked about how deeply entrenched is confessionalism in the society and the Lebanese political system $60 \%$ (40\% strongly agree with the statement and 20\%agree) of the respondents see that "political confessionalism is historically and deeply rooted in Lebanese culture and it cannot be removed, even if the will existed to do so."

Per definition a democratically elected government has the monopoly on the arms and the leadership of the armed forces. That raises the issue of the arms bearing Hezbollah and its role in national defense and what is called "armed resistance". The results of a question in this poll about whether the "Resistance should have sole responsibility for national defense" only $3 \%$ of the respondents saw that Hezbollah should bear the sole responsibility for national defense. $51 \%$ see that national defense is 
the responsibility of the government armed forces alone, with the remaining $45 \%$ seeing that it should be a joined effort between the government forces and Hezbollah. It should be noted however that $82 \%$ of the respondents who were Shiites said that the national defense should be a joint effort between the government armed forces and Hezbollah.

As for the attitude towards the Constitution and whether it should be untouchable and followed to the letter: $51 \%$ of the respondents saw that it is "not permissible to circumvent the constitution under any circumstances." The other half saw that it could be done in some circumstances to preserve national unity. Broken down into different confessions $41 \%$ of the Christians see it permissible to circumvent the constitution in some circumstances, $43 \%$ of the Sunnis agree with this point compared with a high $72 \%$ of the Shiites. The Druzes have the lowest percentage $34 \%$ see it possible to circumvent the constitution in some circumstances. (please see the Information International opinion poll done in December 2004 about the Hezbollah arms, and the attitude towards amending the Constitution, with similar results as the LOAC poll.)

\section{June $2^{\text {nd }}-9^{\text {th }}$, 2008: Information International: Lebanese citizens' attitude} towards politicians.

The survey polled the Lebanese about their attitude towards politicians in general and towards leaders of each religious group: “The poll covered 1000 Lebanese from across the country", with $55.8 \%$ male, and $44.2 \%$ female. The margin of error was $+/-$ 2.4. The notable results were that $78.4 \%$ of the respondents do not trust politicians. 
Addressing the citizens' allegiance to the "za'im" in each confession, 97.4\% of the Shia are loyal to Hassan Nassrallah (the Hezbollah leader) and $96.7 \%$ of the Shia see that Nabih Berri, the leader of Amal, the other Shia party allied with Hezbollah, has an excellent or good performance. The loyalties among the Christians to their leaders is not as high and they have more than one leader, compared with a high degree of loyalty $75 \%$ of the Sunni respondents to their one uncontested leader Sa'ad al-Hairiri.

\section{June $2^{\text {nd }}-9^{\text {th }}, 2008$. Information International : Position towards Arab and foreign countries.}

“The poll covered 1000 Lebanese from across the country", with 55.8\% male, and $44.2 \%$ female. The margin of error was $+/-2.4$. The respondents were polled about "their position towards Arab and foreign countries, relations with Syria and other issues." The results showed that the Lebanese positions towards Arab and foreign countries reflect greatly the attitude of their za'im towards that country. Notable are the answers to the question that asked whether clerics should meddle with politics: $57 \%$ of the respondents said that they should not. 